\title{
Housing in an Example of Low - Rise Residential Structure in Debar Maalo, Skopje
}

\author{
Sinolichka Smilevska*
}

Faculty of Architecture - Skopje, Ss Cyril and Methodius University of Skopje, Skopje, Republic of Macedonia

\begin{abstract}
Citation: Smilevska S. [Housing in an Example of Low Rise Residential Structure in Debar Maalo, Skopje]. SEE J Archit Des. 2019 Dec 23; 10045:1-64. 89/seejad 2019.1004

Keywords: House; Yard; Typology; Housing density *Correspondence: Sinolichka Smilevska. Faculty Architecture - Skopje, Ss Cyril and Methodius University Skopje, Skopje, Republic of Macedonia. E-mai: sinolicka.smilevska@gmail.com

Received: 20-Nov-2019; Revised: 21-Dec-2019; Accepted: 22-Dec-2019; Online first: 23-Dec-2019

Copyright: ๑ 2019 Sinolichka Smilevska. This is an openCress article distributed under the terms of the Creative License (CC BY-NC 4.0).

Funding: This research did not receive any financial support.

Competing Interests: The authors have declared that no competing interests exist.
\end{abstract}

\section{Abstract}

From city quarter with urban villas, yard houses and pittoresque ambient values, Debar Maalo in Skopje in recent time, is turning into a construction site of the intense rise of the building mass and filling in on every potential void, where the typology of multifamily residential buildings is dominant.

But, can it be different? The marginalized forms of single-family housing, once a dominant lifestyle in Debar Maalo, single family yard houses, houses with ground contact are the remains of a passed image of this city quarter that should be the referent milieu of this research. This typology of a low-rise residential structure, should represent the renovation tactics of the the single-family dwelling in this part of the city of Skopje. The creation process of the new urban landscape of housing with characteristics of a dense and low-rise structure will be through the forward two stages: analysis and design. The location of interest will be analysed through architectural project of a housing block with the typology of a low-rise housing structure that should provide high urban density of 120 houses per hectare The suggested typology of the housing structure should provide housing that will meet the new lifestyles and will achieve diversity of the houses according to their size, structure, and comfort.

This thesis should refer to the idea of rethinking and reminiscing on the elementary architectural city image, low rise housing structure typology as a building type at the level of the morphology of the city of Skopje. 
Универзитет "Св. Кирил и Методиј”

Архитектонски фракултет- Скопје

Магистерска теза

\section{Домување во ниска станбена структура на примерот во Дебар Маало, Скопје}

Синоличка Смилевска

Скопје

2019 


\section{Домување во ниска станбена структура на примерот во Дебар Маало, Скопје}

Магистерска теза

Синоличка Смилевска

Ментор:

Доц. д-р Саша Тасиќ

Комисија за одбрана:

Вонр. профр. д-р. Александар Радевски

Вонр. проф. д-р. Дивна Пенчиќ 


\section{АПСТРАКТ}

Од градски кварт со урбани вили, куќи со дворови и питорескни амбиентални вредности, Дебар Маало во Скопје во рецентно време се претвора во градилиште на интензивно згуснување на градежната маса и пополнување на секоја потенцијална празнина, каде доминира типологијата на повеќесемејните станбени згради. Но, дали може поинаку? Маргинализираните форми на едносемејно домување од некогаш доминантниот начин на живеење во Дебар Маало, едносемејните куќи со двор, куќите со контакт со теренот, се остатоци на некогашната слика на овој градски кварт кои треба да бидат референтна подлога во ова истражување. Оваа типологија на ниската станбена структура, треба да претставува тактика за обновување на едносемејното домување во овој дел на градот Скопје. Процесот на создавање на нов урбан пејзаж на домување со карактеристики на ниска густа станбена структура, ќе биде проследен низ две фрази: аналитичка и проектанска. Предметната локација ќе биде истражувана преку архитектонски проект на станбен блок преку типологијата на ниската станбена структура која треба да обезбеди висока урбана густина на населеност од 120 куќи на хектар. Предложената типологија на станбената структура треба да обезбеди домување кое ќе ги престретне новите животни стилови и ќе постигне диверзитет на куќите според нивната големина, структура и комфор.

Овој труд треба да упати на идејата за преобмислување и повторно навраќање на најелементарната архитектонска претстава во градот, типологијата на ниската станбена структура, како градителски тип на ниво на морфологијата на градот Скопје.

клучни зборови: куќа, двор, типологија, густина на домување 


\section{ABSTRACT}

From city quarter with urban villas, yard houses and pittoresque ambient values, Debar Maalo in Skopje in recent time, is turning into a construction site of the intense rise of the building mass and filling in on every potential void, where the typology of multifamily residential buildings is dominant.

But, can it be different? The marginalized forms of single family housing, once a dominant lifestyle in Debar Maalo, single family yard houses, houses with ground contact are the remains of a passed image of this city quarter that should be the referent milieu of this research. This typology of a low rise residential structure, should represent the renovation tactics of the the single family dwelling in this part of the city of Skopje. The creation process of the new urban landscape of housing with characteristics of a dense and low rise structure will be through the forward two stages: analysis and design. The location of interest will be analysed through architectural project of a housing block with the typology of a low rise housing structure that should provide high urban density of 120 houses per hectare. The suggested typology of the housing structure should provide housing that will meet the new lifestyles and will achieve diversity of the houses according to their size, structure and comfort.

This thesis should refer to the idea of rethinking and reminiscing on the elementary architectural city image, low rise housing structure typology as a building type at the level of the morphology of the city of Skopje.

key words: house, yard, typology, housing density 


\section{СОДРЖИНА}

\section{АПСТРАКТ}

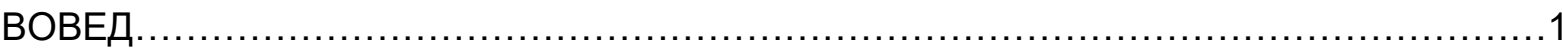

1. Теоретско истражување во типологијата на ниската станбена структура како

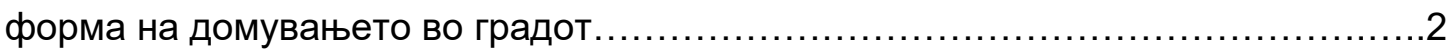

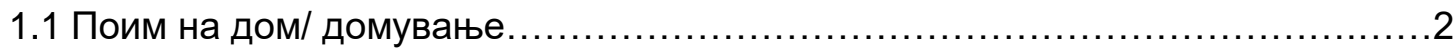

1.2 Типологија на ниска станбена структура.........................................

1.2.1 Физички карактеристики на ниска станбена структура...................4

1.2.2 Просторни карактеристики на ниска станбена сруктура...................5

1.2.3 Социјални карактеристики на ниска станбена структура....................8

2. Историски и современи примери домување со карактеристики на густо

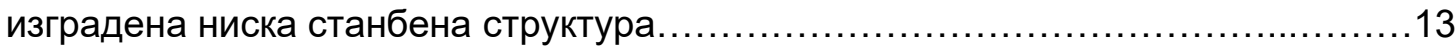

2.1 Историски увид во урбаното домување..................................... 13

2.2 Едносемејно домување на примерот на Скопје низ времето....................16

2.2 .1 Период меѓу двете светски војни................................... 17

2.2.2 Период после вторта светска војна.....................................18

2.3 Современи примери на едносемејно домување, групни форми

2.3.1 Adriaan Geuze, West 8, Borneo \& Sporenburg, Amsterdam 1993...........22

2.3.2 Atelier 5, Halen Estate, Bern, Switzerland 1960 ..........................23

3. Предлог на концепт решение на нов станбен кластер од едносемејни куќи во

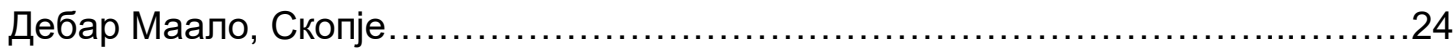

3.1 Типоморфолшка анализа на просторниот контекст на локацијата...............24

3.1.1. Архитектонско документирање на референтни објекти во Дебар

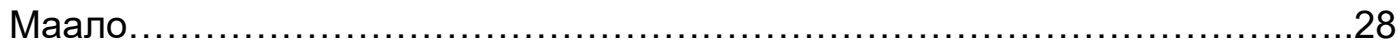

3.2 Архитектонско образложение на концептот................................42

3.2.1.Анализа на урбан опфат............................................... 42

3.2.2 Анализа на архитектонско- урбанистичкиот зафат.......................44

3.2.3 Анализа на архитектонски концепт.......................................46

3.2.4 Програмска анализа по спратови......................................49

3.2.5 Конструкција и применети материјали.................................52

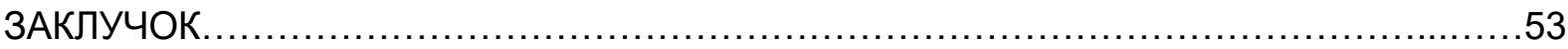

БИБЛИОГРАФИЈА 


\section{ИЛУСТРАЦИИ: Слики/ Табели}

сл.1 - пример на физичка структура , ирегуларна морфолошка матрица на ниска станбена структура,

достапно на: https://poster-gallery.com/en/shop/view_product/Gerster-Georg-Foto-ohne-Worte-

Swissair-Algerien-775601;

сл.2 - типологија на ниската станбена структура,

(од авторот);

сл. 3 - Robie House, Frank Lloyd Wright, Chicago, 1910,

достапно на: https://franklloydwright.org/site/robie-house/;

сл. 4 - Куќи во низа, Амстердам, Борнео и Споренбург,

достапно на: https://www.mvrdv.nl/projects/162/borneo-18;

сл. 5 - House X, Nürnberg,

достапно на: https://netzwerkarchitekten.de/projekte/haus-x-nuernberg/;

сл.6 - индивидуално домување, социолошки пресек,

(од авторот);

сл.7 - заеднички простор за социјализација на едно соседство,

превземено од: електорнска книга “A Pattern Language, Towns, Buildings, Construction”, 1977, Christofer Alexander;

сл.8 - заеднички простор за споделување на ниво на семејство,

превземено од: електорнска книга “A Pattern Language, Towns, Buildings, Construction”, 1977, Christofer Alexander;

сл.9 - заеднички простор за споделување на ниво на пар,

превземено од: електорнска книга “A Pattern Language, Towns, Buildings, Construction”, 1977, Christofer Alexander;

сл.10 - ниши- соби, ниво на приватен домен на домување на корисник,

превземено од: електорнска книга “A Pattern Language, Towns, Buildings, Construction", 1977, Christofer Alexander;

сл. 11 - Рустикална колиба, Laugier,

достапно на: http://chuansong.me;

сл. 12 - Станбени атриумски низи, Olyntus,

достапно на: https://jfk2xv.files.wordpress.com;

сл. 13 - Атриумска куќа, Roman Domus,

достапно на: http://www.legendsandchronicles.com;

сл. 14 - Атриумска низа, Casa Cogolio, Vicenza, A. Paladio, 1776,

достапно на: https://commons. wikimedia.org;

сл. 15 - Павиљон, De l'espirit Nouveau, Ле Корбизие, 1925,

достапно на: https://archiladymenabo.files.wordpress.com;

сл. 16 - Улична линија на едносемејни куќи, ул. "Истарска”, Ново Маало, Скопје,

автор Профр. д-р. Минас Бакалчев;

сл. 17 - Куќата на семејството Шкаперда, архитект Георги Симота, Скопје, 1939 год., достапно на: https://www.mkd.mk/zabava/domashna/shkaperda-kukjata-od-najubavite-sonishta...;

сл.18 - Железничка колонија, Скопје, 1929,

достапно на: http://www.build.mk/forum/forum_posts.asp;

сл. 19 - Градска вила на ул. “Орце Николов”, архитект Лудјек Кубеш, Скопје, 1952,

автор Проф. д-р. Минас Бакалчев;

сл. 20 - Двојни куќи градени во периодот после втората светска војна, населба Мичурин, Скопје (стр.20)

сл. 21 - Мексиканските бараки по проект на архитект Pedro Ramirez Vasquez, Тафталиџе, Скопје достапно на: http://periferijanazivotpokrajpcelite.blogspot.mk;

сл.22 - Просторен план на Borneo \& Sporenburg, Амстердам, 1933

достапно на: http://arquiscopio.com/archivo/2012/05/27/masterplan-de-borneo-sporenburg;

сл. 23 - Halen Estate, типологија на куќи во низа, превземено од веб страната на Atelier 5, достапно на: https://atelier5.ch/arbeiten/1961-siedlung-halen-herrenschwanden; 
сл.24 - местоположба на Дебар Маало во Општина Центар, Скопје, превземено од Google maps и графички доработувано од авторот;

сл.25 - местоположба на Дебар Маало 1, превземено од Google maps и графички доработувано од авторот;

сл.26 - Планиран развој на населба Дебар Маало, превземено од веб списнието на Порта 3 , достапно на: https://www.porta3.mk/i-ova-e-skopje-od-tesno-potesno-ii-del-debar-maalo-eliten-kvart/ ; сл.27 - денешна слика на Дебар Маало, превземено од веб списнието на Порта 3 достапно на: https://www.porta3.mk/i-ova-e-skopje-od-tesno-potesno-ii-del-debar-maalo-eliten-kvart/ ; сл.28 - висока густина на градба достапно на: https://www.porta3.mk/i-ova-e-skopje-od-tesno-potesno-ii-del-debar-maalo-eliten-kvart/ ; сл.29 - станбена зграда на д-р. Рубен, градител Иван Артемушкин превземено од “Градителите во Македонија XVIII-XX ВEК”, Георги Константиновски; сл.30 - индивидуална семејна куќа, градител Вајчеслав Бујко превземено од “Градителите во Македонија XVIII-XX ВЕК”, Георги Константиновски; сл.32 - основа на инд. сем. Куќа, градител Борис Дутов

превземено од “Градителите во Македонија XVIII-XX ВЕК”, Георги Константиновски; сл.33 - градител Борис Дутов превземено од “Градителите во Македонија XVIII-XX ВEК”, Георги Константиновски; сл.34 - инд. сем. Куќа, градител Кирил Жерновски превземено од “Градителите во Македонија XVIII-XX ВEК”, Георги Константиновски; сл.35 - станбен објект, градител Кирил Жерновски превземено од “Градителите во Македонија XVIII-XX BEК”, Георги Константиновски; сл.36 - станбен објект, градител Драгутин Илиќ превземено од “Градителите во Македонија XVIII-XX ВЕК”, Георги Константиновски; сл.37- основа на инд. сем. куќа, градител И. Кавтиќ

превземено од “Градителите во Македонија XVIII-XX ВЕК”, Георги Константиновски; сл.38 - основа на инд. сем. куќа, градител Милан Карло Котек превземено од “Градителите во Македонија XVIII-XX ВEК”, Георги Константиновски; сл.39 - инд. сем. куќа, градител Фердо Краус превземено од “Градителите во Македонија XVIII-XX BEК”, Георги Константиновски; сл.40 - инд. сем. Куќа, градител Михаил Матвеев превземено од “Градителите во Македонија XVIII-XX ВЕК”, Георги Константиновски; сл.41 - основа на инд. сем. Куќа, градител Исајло Јованов Николовски превземено од “Градителите во Македонија XVIII-XX ВЕК”, Георги Константиновски; сл.42 - инд. сем. Куќа, градител Исајло Јованов Николовски превземено од “Градителите во Македонија XVIII-XX ВEК”, Георги Константиновски; сл.43 - основа на инд. сем. Куќа, градител М. Тасиќ превземено од “Градителите во Македонија XVIII-XX ВЕК”, Георги Константиновски; сл.44 - основа, Глигорие Ташковиќ превземено од “Градителите во Македонија XVIII-XX ВEК”, Георги Константиновски; сл.45 - станбен објект, Глигорие Ташковиќ превземено од “Градителите во Македонија XVIII-XX ВЕК”, Георги Константиновски; сл.46 - основа, Пајо Шулентиќ превземено од “Градителите во Македонија XVIII-XX ВEК”, Георги Константиновски; сл.47 - инд. сем. Куќа, градител Пајо Шулентиќ превземено од “Градителите во Македонија XVIII-XX ВEК”, Георги Константиновски; сл.48 - станбен блок, градител Петко Јосифовски превземено од “Градителите во Македонија XVIII-XX ВEК”, Георги Константиновски; сл.49 - станбен објект, градител Лудјек Кубеш превземено од “Градителите во Македонија XVIII-XX ВEК”, Георги Константиновски; сл.50 - карактеристичен кат на станбена кула, градител Васка Ладинска превземено од “Станбени повеќекатници, Кули”, Јован В. Ранковиќ; сл.51 - станбен блок, градител Љубомир Томиќ превземено од “Градителите во Македонија XVIII-XX ВЕК”, Георги Константиновски; 
сл.52 - станбен блок, градител Драган Томовски

превземено од “Градителите во Македонија XVIII-XX ВEК”, Георги Константиновски;

сл.53 - основа на инд. сем. куќа, градител Сотир Томоски

превземено од “Градителите во Македонија XVIII-XX ВEК”, Георги Константиновски;

сл.54 - станбен блок, градител Имре Фаркаш

превземено од “Градителите во Македонија XVIII-XX ВEК”, Георги Константиновски;

сл.55 - мапирање на улици на документирани објекти

(од авторот);

сл.56 - мапа на улици на документирани објекти

(од авторот);

Табела 1- градежен фонд 1918-1944/ 1944-2000

(од авторот);

сл.57 - графички приказ на К.П на предметниот опфат

превземено од веб страна на Агенција за катастар на недвижности, достапно на:

http://gis.katastar.gov.mk/arec;

сл.58 - ДУП донесен 11.2012

превземено од веб страна на Општина Центар, достапно на: https://www.centar.gov.mk;

сл.59 - Приказ на изградена/ неизградена површина(полно/ празно)

(од авторот);

сл.60 - Приказ на неизградена/ изградена површина (полно/ празно) на локацијата

(од авторот);

Табела 2 - Табела со нумерички податоци за објектите и површината што ја зафаќаат

(од авторот);

сл. 61 - Шематски приказ на сообраќајното решение на опфатот

(од авторот);

сл.62 - Шематски приказ на употребена модуларна мрежа

(од авторот);

сл.63 - Шематски приказ на употребени типови и нивна местоположба во рамките на опфатот

(од авторот);

сл.64 - мапирање на социјалните содржини

(од авторот);

сл.65 - графички приказ на основа на подрум

(од авторот);

сл.66 - графички приказ на основа на приземје

(од авторот);

сл.67 - графички приказ на основа на прв кат

(од авторот);

сл.68 - графички приказ на основа на втор кат и петта фрасада

(од авторот); 


\section{ВОВЕД}

Предмет на истражувањето на овој магистерски труд претставува индивидуалното домување во типологијата на ниските станбени структури, како модели на домување кои овозможуваат истовремено поголеми социјални интеракции и кохезија кај корисниците и овозможува постигнување на висока урбана густина на населеност на градот.

Целта на ова истражување е да се нагласи потребата за постоење на архитектонска типологија на една витална просторна форма на домување, едносемејните куќи на ниво на градот Скопје; нагласување на социјалната структура која е поврзана со архитектурата на едносемејна куќа и човекомерноста на соодносот на изградените единици и неизградениот простор; да се овозможи синтезата на природата и архитектурата во текстурата на градот на ниво на единица на блокот Дебар Маало, преку архитектонски проект за домување проследен преку типологијата на ниската станбена структура и истовремено постигнување на висок степен на урбана густина.

Методологијата на истражување ја опфаќа теоретската подлошка на типологијата на ниската станбена структура како фрорма на домување во градот преку нејзините фризички, просторни и социјални карактеристики; анализа на референтни примери на домувањето кое ги поседува карактеристиките на живеење во типологијата на ниската станбена структура; типоморфолошка анализа на локалниот контекст на предметната локација и на крај истражување преку архитектонски проект, како тактика за генерирање на еден нов локален прототип на домување во Дебар Маало, станбена група, кластер од едносемејни куќи. 


\section{1. ТЕОРЕТСКО ИСТРАЖУВАЊЕ ВО ТИПОЛОГИЈАТА НА НИСКАТА СТАНБЕНА СТРУКТУРА КАКО ФОРМА НА ДОМУВАҢЕТО ВО ГРАДОТ}

\section{1 Поим на дом/домување}

Поаѓајќи од основната човечка потреба за засолниште, палеолитскиот човек (30000 год. пред н.е) ја наоѓa првобитната фризичка фрорма на домување во природата пештерата. Археолошките наоѓалишта сведочат дека овој прв простор-скривалиште е организиран и употребуван на повеќе начини за кое сведочат насликаните делови кои се интерпретирани како светилишта.

Од пронаоѓање на засолниште во природата, човековата еволуција води до создавање на структура- куќа.

Развојот и различната форма која ја завзема домувањето/ домот низ историјата се условени од географските, климатските, социјалните, ритуалните, економските фрактори.

Главните двигатели на континуираната трансформација на домот и домувањето денес се: социјалната интеракција и адаптација на индивидуалните социолошки побарувања низ сите фрази на животот; променливите услови за работа; проблемите на енергија, ресурси и еколошки баланс; промената на местото (topos) земајќи ги предвид вградувањата и адаптацијата на историскиот и урбаниот контекст; индивидуалната перцепција на феномените како: светлина, материјали и мемории.

Куќата, домот, престојувалиштето на човекот или неговото живеалиште се неделиви компоненти на домувањето и заедно претставуваат своевиден феномен во кој се одвива индивидуалниот и заедничкиот живот на човекот.

Домот е фризичка, просторна и социјална структура создадена од човекот. Физичката структура на домот ја дефинира неговата материјалност- интервенција во пејсаж, присвојување/ одбележување на одредена територија за употреба како простор за живеење со физичка видливост; просторната структура е дефинирана од системот на простори кои ја сочинуваат- внатрешни, надворешни, меѓу- простори и нивната големина, поставеност и начин на меѓусебно поврзување соодветствува со потребите на корисникот/ корисниците; социјалната структура на домот е создадена од културата и меѓусебните односи на корисниците.

Домувањето има двојно значење: домување како активност на живеење и домување како место или структура (културен и материјален аспект на живеењето). ${ }^{1}$

Поимот домување, според Богдан Несторовиќ, опфаќа различни манифестации на човечкиот живот, условени со фризиолошките, социолошките и психолошките потреби на човекот. Сите овие манифестации, помалку или повеќе, се појавуваат кај секое домување, но начинот на кој се манифестира, не е секогаш ист. ${ }^{2}$ Според М. Хајдегер (М. Heidegger) домувањето во најголем степен го одразува суштествувањето на човекот на земјата. Суштината на вака дефинираното домување Хајдегер го објаснува со првобитното значење на германскиот збор bauen, што се применува за градење, што значи домување. ${ }^{3}$ Оттука „домувањето

\footnotetext{
1 Oliver, P., Dwelings. The House across the World, Phaidon, Oxford, 1987

${ }^{2}$ Nestorović, B., Stambene zgrade. Naučna Knjiga, Beograd, 1952, str.1

${ }^{3}$ Стариот збор bauen, на кој му припаѓ bin, одговара дека ichbin du bist значи: јас живеам, ти живееш. Начинот на кој ти си и на кој јас сум (du bist und ich bin), начинот на кој ние луѓето сме на земјата.....домувањето (живеењето) е начин на кој смртниците (луѓето) постојат на земјата. Да бидеш човек, значи да живееш.
} 
е основно начело на постоењето“. ${ }^{4}$ Во согласност со ваквиот поим зборот домување значи повеќе од физичко засолниште. Во таа смисла според Кристијан Норберг Шулц (C. Norberg-Schulz), домувањето се одвива на четири нивои. ${ }^{5}$ Одредиштето што се формира со самиот чин на населување претставува одговор на исконската потреба на човекот да си обезбеди место на потпора во дадениот свет. Одредиштето дејствува пред се како место на состанувања каде човечките суштества можат да ги разменуваат своите производи, идеи и чувства. Потоа човекот домува во населбата и нејзиниот урбан простор во смисла да стекнува искуство за можностите што ги пружа светот, во чувствувањето на тој простор како амбиент на можности, како место на „колективно“ живеење. ${ }^{6}$ „Живеењето во смисла на домување го опфаќа она повлекување што е неопходно за одредување и одржување на сопствената самобитност, во поседувањето на мал издвоен свет, во куќата како приватно место и прибежиште на секој поединец“. ${ }^{7}$

Домувањето е процес и артефакт. Процес на живеење во дадена локација и негов фризички израз. Гледано од просторен аспект, општествата варираат, не само во типот на физичката конфигурација , туку и во нивото на кој се појавува редот во просторот како нагласен дел на културата. Некои општества инвестираат повеќе во физичко моделирање на просторот од други, додека едни имаат неформални, органски модели, други имаат чисто глобални, дури геометриски форми; некои општества вградуват социјално значење во просторните форми, други имаат препознатливи просторни форми, но со недостаток на некаква инвестиција во социјалното значење. ${ }^{8}$

Формата на домувањето не е директен резултат на фризички фрактори или еден единствен причинско-последичен фактор, но консеквенца на цела низа социо-културни (примарни) и фризички (секундарни модифицирачки) фрактори. ${ }^{9}$

Животната средина рефрлектира низа социо-културни сили: религиозни верувања, структура на домаќинство, социјална организација, социјални односи. Градбите и населбите се видлив израз на релативната важност дадена на различните аспекти на животот и различните начини да се гледа реалноста.

Значи домувањето на човекот како начин и избор на животот, може да се реализира во куќа како приватно прибежиште давајќи му индивидуален карактер на домувањето, или во куќа како заедничко прибежиште, дом за поголема група на луѓе давајќи му колективен карактер на домувањето. Во двата случаи доаѓа до полн израз фундаменталната функција на домувањето, суштествувањето на човекот на земјата. „Односот на човекот и просторот не е ништо друго освен живеење, сфратено во неговата суштина“. ${ }^{10}$

\footnotetext{
${ }^{4}$ Hajdeger, M., Misljenje i pevanje. Gradjevinska knjiga, Beograd, 1982. str.85-87

${ }^{5}$ Norberg-Schulz, C., Stanovanje. Gradjevinska knjiga, Beograd, 1990. str.13

6 Терминот „колективен“ Норберг-Шулц го користи во неговото изворно значење, што значи собирање.

7 Блажевска, 3., Повеќедворната станбена куќа во фрункција на хумано домување на старите луѓе во рамки на семејството, необјавен докторски труд, Универзитет Св. Кирил и Методиј, Архитектонски фракултет, Скопје, 1991. стр.83

8 Hillier, B., Hansenb, J., The Social Logic of Space, Cambridge University Presse, 1984

9 Rapoport, A., House form and Culture, Prentice-hall, Inc. Englewood Cliffs,N.J., 1969

10 Norberg-Schulz, C., Egzistencija, prostor i arhitektura. Gradjevinska knjiga, Beograd, 1975. str.98
} 


\section{2 Типологија на ниска станбена структура}

Типологијата е пристап која ги изолира атрибутите на архитектонсата разбирливост, ги идентификува како карактеристики, со цел да ги спореди со слични апстрахирани атрибути од други контексти и да ги десинира сличностите или разликите. ${ }^{11}$

Типот не е измислен, не е дизајниран, не е разработен. Типот се појавува, расте, кулминира, се распаѓа, се порамнува. Типовите се "органски" конкретни. Овие термини може да звучат дифузно, можат да одведат во погрешна насока, но прецизно ја потенцираат разликата помеѓу тип и објективен прототип. ${ }^{12}$

Типологиите во домувањето се класифицираат според различни аспекти, категории, својства. Материјалните аспекти на домувањето ја дефинираат физичката структура на домот, системот на простори кои го сочинуваат домот ја формираат неговата просторна структура; аспектот на меѓучовечките односи ја означуваат социјалната структура на домувањето.

\subsection{1 Физичка структура}

Домот (архитектурата) е фризички френомен (материјален артефакт). Во таа смисла може да се класифицира по различни фризички атрибути. Висината е еден од стандардните пристапи во класифицирање на архитектонската структура. Така, според фризичката карактеристика на домувањето се групираат: ниска, средна и висока станбена структура. Ниската станбена структура, која е предмет на истражување, подразбира градби со максимум 3 станбени единици.

Предностите на живеењето целосно на приземно ниво, ги придвижи некои од раните репрезентативци на Модернистичкото движење да ги испитаат формите на ниските станбени живеалишта како тие на кои е заснована идејата за град-градина. Валтер Гропиус ги критикуваше овие цели, тврдејќи дека тие се несоодветни за масовно домување, тргнувајќи од идејата дека приземната форма означува "негација и распаѓање на градот”. Спротивставувајќи се на овој аргумент, Лудвиг Хилбершајмер тврдеше дека секому треба да биде дозволено да го избира типот на живеалиште кој го преферира. Домувањето во ниска станбена структура со градини е подобра за фамилии со деца, додека за паровите без деца или самците, имаат тенденција да преферираат живеење во високи структури со заеднички простории. Затоа тој се повикува на мешовити високи и ниски станбени структури.

Ништо не е променливо како самата промена. Распонот на типологијата на станбените структури во иднината, на пример, ќе продолжат да бидат под влијание на условите кои ги формираат патерните на живеење. Итните цели на 21от век драстично ги менува енергетските парадигми во поглед на миграцијата и заканите од климатските промени секако ќе водат кон интересни нови варијации во фрормата на домувањето со висока станбена густина. ${ }^{13}$

\footnotetext{
${ }^{11}$ Lack, Peter, Bruno Reichlins gebaute Architecturkritik, VDG Verlag and database for humanities, Weimar 1955, стр. 93

12 Teut, Anna, "Von Typen und Normen, Maßreglern und Maßregelungen”, Architektur und technisches Denken, 1985, стр. 53 ${ }^{13}$ Detail, "Small- Scale housing", Low-Rise Housing Typology, Достапно на: [https://www.detail-online.com/article/low-risehousing-typology-14520/] , 2010
} 


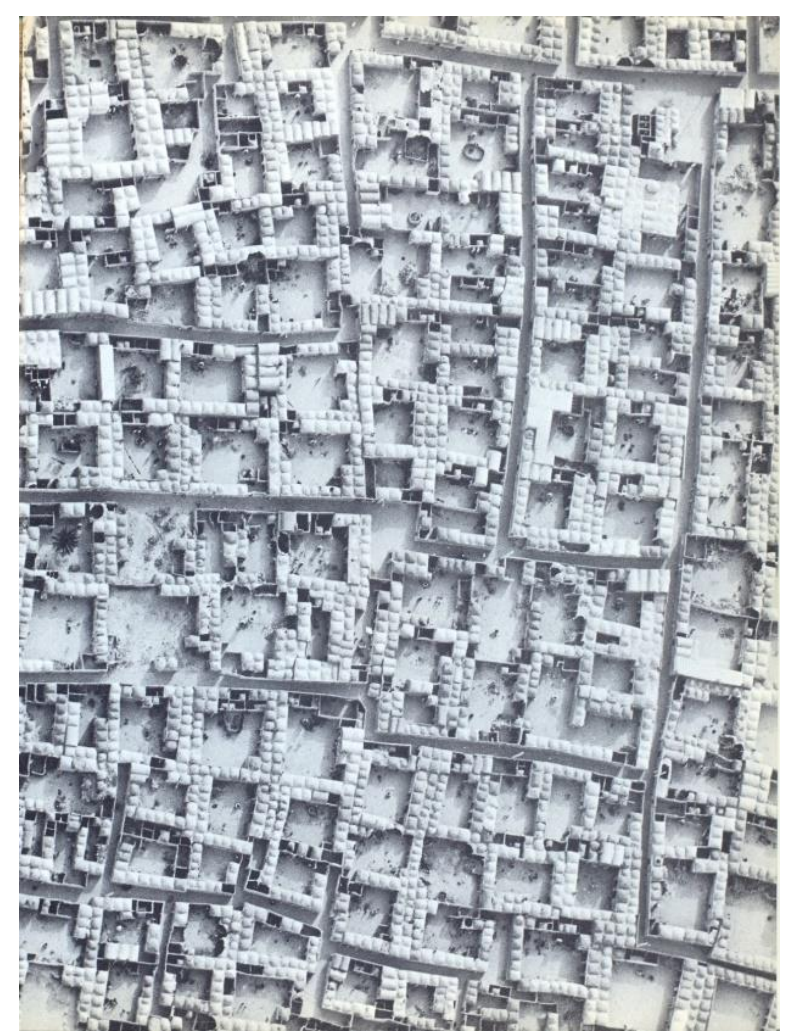

сл.1 - пример на физичка структура , ирегуларна морфолошка матрица на ниска станбена структура

\subsection{2 Просторна структура}

Архитектурата е просторен феномен, не е само физичка структура. Во себе дефинира просторна организација и употреба (со тоа се разликува од уметнички артефракт). Во однос на типологијата на домувањето на ниската станбена структура препознаваме: поединечна куќа (молекуларна структура/ архитектура-природа); двојна куќа- низа (линијска структура/ улична слика); атриумска куќа (површина/ урбана структура).

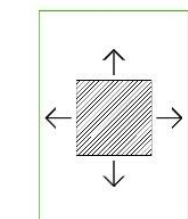

ПОЕДИНЕЧНА КУК̈А

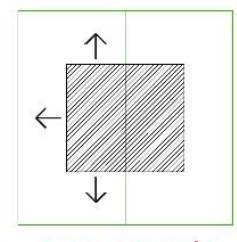

ДВОЈНА КУК̈А

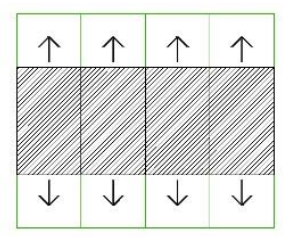

КУК์И ВО НИЗА

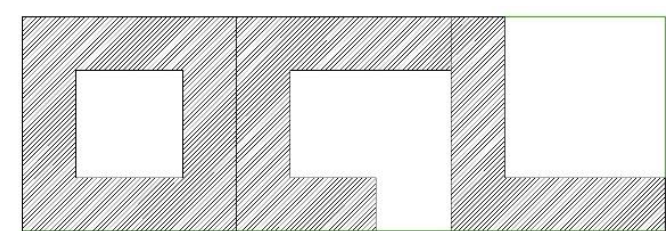

АТРИУМСКИ КУЌИ

сл.2 - типологија на ниската станбена структура

Поединечната куќа, строго кажано, не е типолошка категорија на домувањето. Поимот поединечна куќa или слободностоечка куќа се однесува на урбанистичка типолошка категорија. Поединечните куќи можат да бидат категоризирани според пристапот, ориентацијата или просторната организација, но сите овие категории се повторуваат во нови формации и можат да се разгледуваат како типолошки карактеристики. Прегледот на поединечните куќи помалку се однесува на типолошките карактеристики на организацијата на катот, а повеќе се фокусира на проблемот со структуралната интеграција на урбано ниво. Тука се среќаваме со нерешлив конфликт, бидејќи урбаните простори не се формирани само од поединечните куќи. Поединечната куќа се стреми да биде независна и остварува отпор да кон типолошкото класифицирање. Поставеноста на поединечната куќа овозможува поголем избор за природна осветленост, ориентација, просторна структура и додатни надворешни површини, 
внатрешна и надворешна цркулација, погледи... Бидејки поединечната куќа е слободностоечка, градбата е отворена кон сите насоки. Патот на светлината може да се проследи низ целата куќа: утринската светлина пробива за врема на појадокот, сончевата платформа е насочена кон југ, дневните простории се насочени кон запад, а ателјето и просториите за работа се обезбедени со северна дифузна сончева светлина. Нејзината ориентација овозможува врамување на различни глетки- ако не се обструирани од соседни згради- или, алтернативно, да ги блокираат несаканите глетки. Слободностоечката куќа му овозможува на дизајнерот неограничена слобода , како во дизајнот, така и во одговорот на условите на локацијата и нејзиниот контекст според желбите на идните резиденти. Ова можеби објаснува зошто поединечната/ слободностоечка куќа сѐ уште, од многумина е гледана како тип кој овозможува идеален начин на живот. Нејзината одвоена поставеност ја отелотворува желбата за максимална можна слобода и независност. Иако веќе долго време сме свесни дека ветувањето за автономија е повеќе илузија отколку реалност, од психолошка гледна точка, чувството за индивидуализам е можеби одлучувачки фрактор за поуларноста на “слободностоечката куќа".

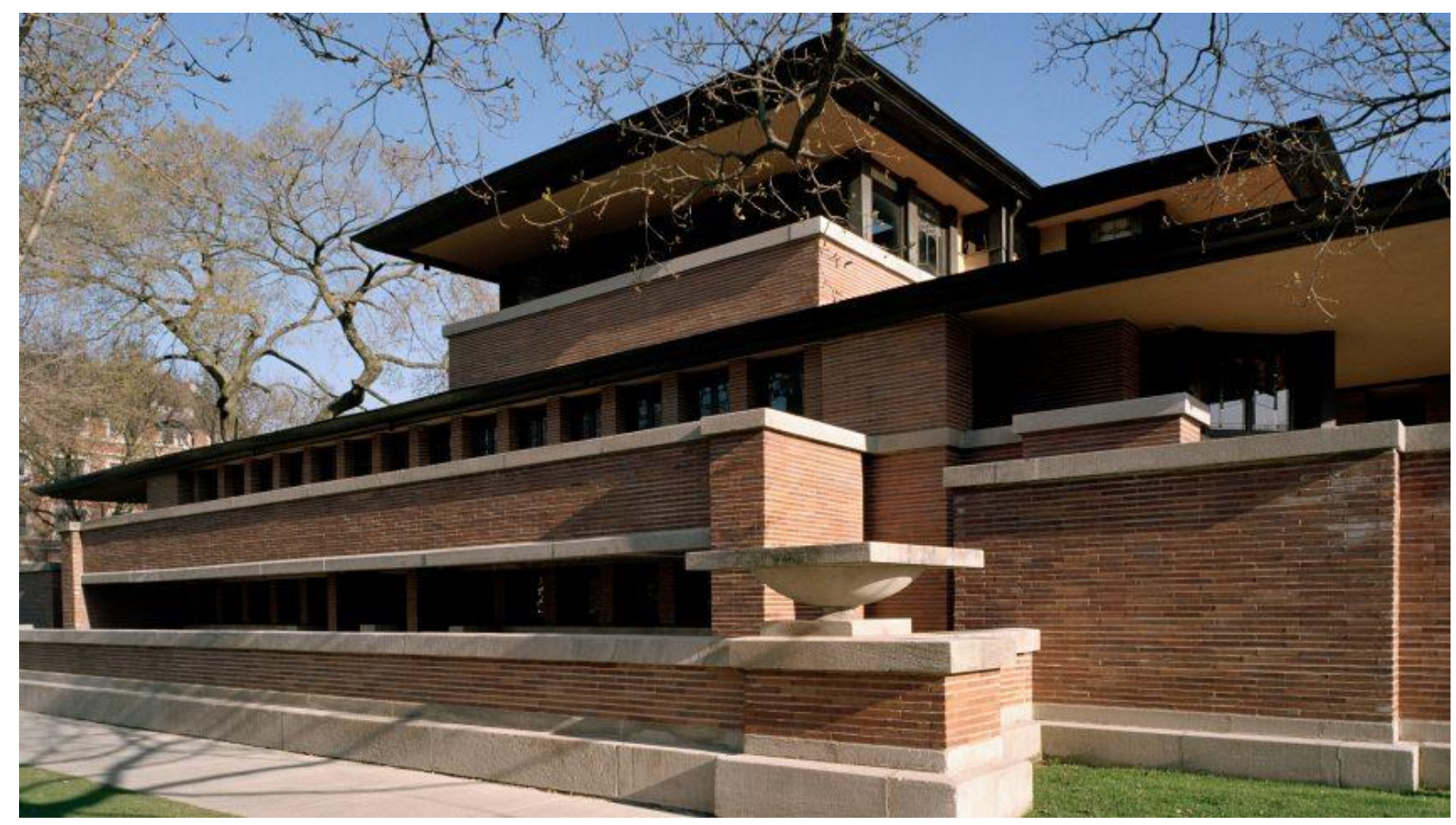

сл. 3 - Robie House, Frank Lloyd Wright, Chicago, 1910

Поимот повторување или репетиција може да има негативна конотација како синоним за монотонија, тага и здодевност.

Принципот на репетиција е секогаш присутен во и ја формира основата на живиот свет на нашата планета: пулс, дишење, циклусот на годишните времиња... Принципот на репетиција го претставува континуитетот, доверливоста, стабилноста и хомогеностаатрибути кои носат позитивна денотација.

Репетицијата е принцип својствен за секоја структура. Кога мислиме на музика, важноста на повторувањето станува очигледна кога ја откриваме разбирливоста. Ритамот и мелодијата ја носат композицијата, различните темпа и варијации го обојуваат делото. Само репетицијата на овие елементи ја откриваат разбирливоста на композицијата.

Така мултипликацијата на основниот тип на поединечната куќа и нејзиното спојување на една или две страни доведува до формирање на двојни куќи, куќи во низа, линијска 
структура, улична слика. Типологијата на куќите во низа е основана на принципот на повторување во нејзината најдобра смисла- под услов повторувачкиот елемент да е вреден за повторување, и доколку методот на повторување не е монотон.

Мултипликацијата на основниот тип на поединечната куќа и нејзиното спојување доведува до фрормирање на развој на густината која е соодветна за одржливи урбани структури на домување.

Куќите во низа не претставувале секогаш позитивна конотација. Куќите за работниците на почетокот на идустријализацијата повеќе служеле за зголемување на профитот на индустриите отколку да ги задоволат потребите на жителите- гледано од денешна перспектива. Нижење на апсолутно идентични единици може да доведе до банални линеарни структури, со недостиг на било каква урбана акцентираност.

Силната страна на низата лежи во нејзината економска исплатливост. Едноставниот и рационалниот принцип на додавање овозмозможува да се подигнат голем број на живеалишта во кратки временски рамки. Истовремено, способноста на спојување на единици едни со други води до избалансиран сооднос на простор за живеење, површина и волумен, што води до креирање на предност на карактеристиките на енергетска ефикасност. Кога деловите за циркулација се интелигентно дизајнирани, куќата во низа нуди повеќе можности за зголемување и намалување на големината на индивидуалната единица. Комбинациите полесно можат да се менаџираат отколку кај атриумските куќи, кои условуваат менаџирање во три насоки.

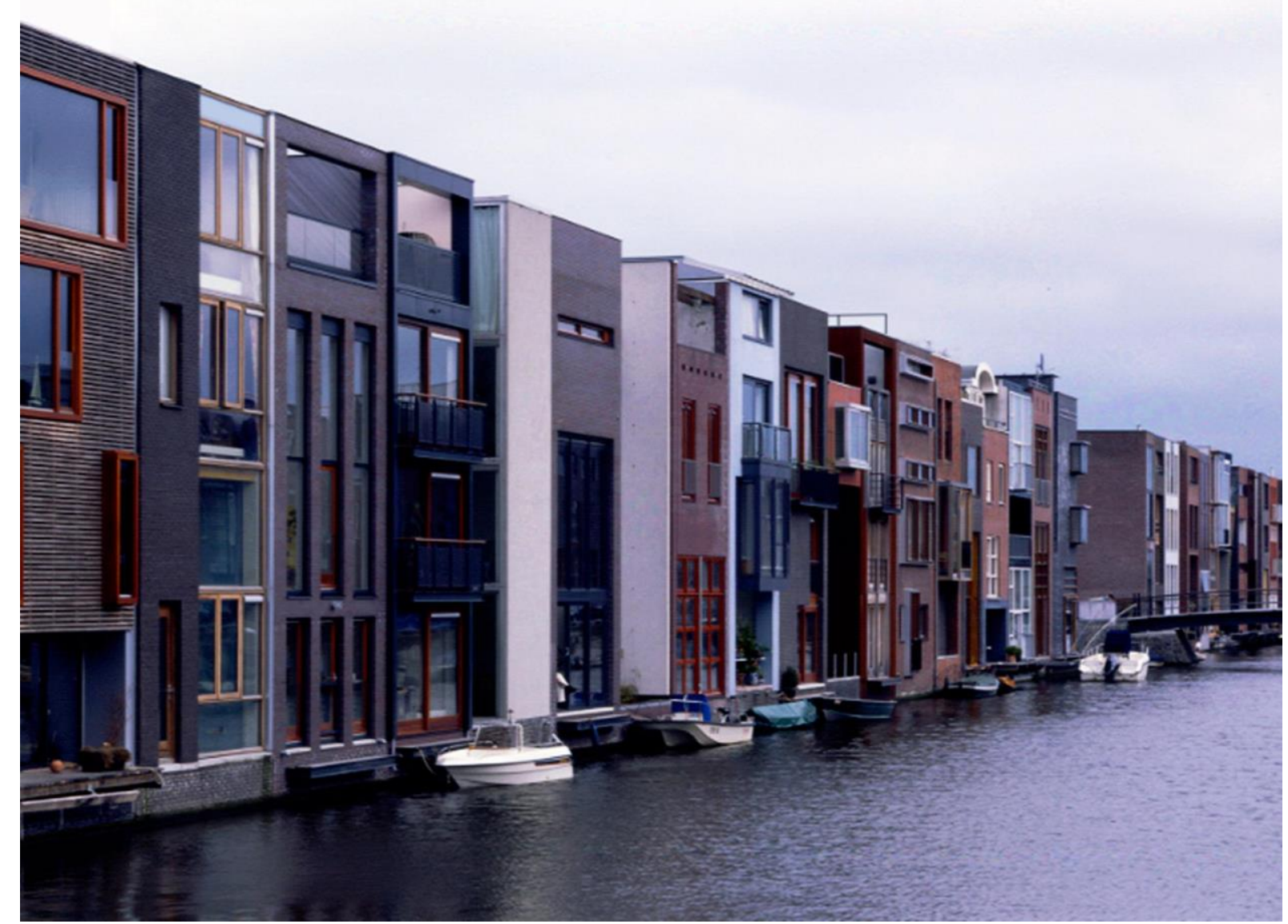

сл. 4 - Куќи во низа, Амстердам, Борнео и Споренбург

Атриумската куќа, со нејзината главна карактеристика- внатрешниот двор, се стреми кон автономија и приватност. Интровертната природа на атриумската куќа, со нејзиниот внатрешен двор како сокриен отворен простор е централен елемент кој исто така се користи за обезбедување на природна светлина и венилација. Атриумската 
куќa го носи потенцијалот за решавање на многу од проблемите врзани за домувањето. Просторната концепција на атриумската куќа со својата способност да се врзува со други куќи на три страни придонесува во развојот на високата урбана густина. Клучните фрактори кај атриумската куќа се употребата на на соодветни пропорции и ориентација на атриумот, бидејќи во екстремни случаи овој типолошки елемент е единствен извор на природна сончева светлина. Така, задолжително е да се испита дали доволно светлина е обезбедена за градбата. Ориентацијата и висината на градбата треба да бидат испитани во рамките на урбаниот контекст. Интимниот карактер на атриумот може да биде зголемен, а со тоа и да се задоволат зголемените барања на приватност. Можноста да се вклучат повеќе од еден атриум овозможува да се диференцираат на атриуми кои обезбедуваат сончева светлина, рекреативни атриуми со зелени површини, “енергетски атриуми”, пристапни атриуми и секој од нив да се карактеризираат со различен степен на приватност.

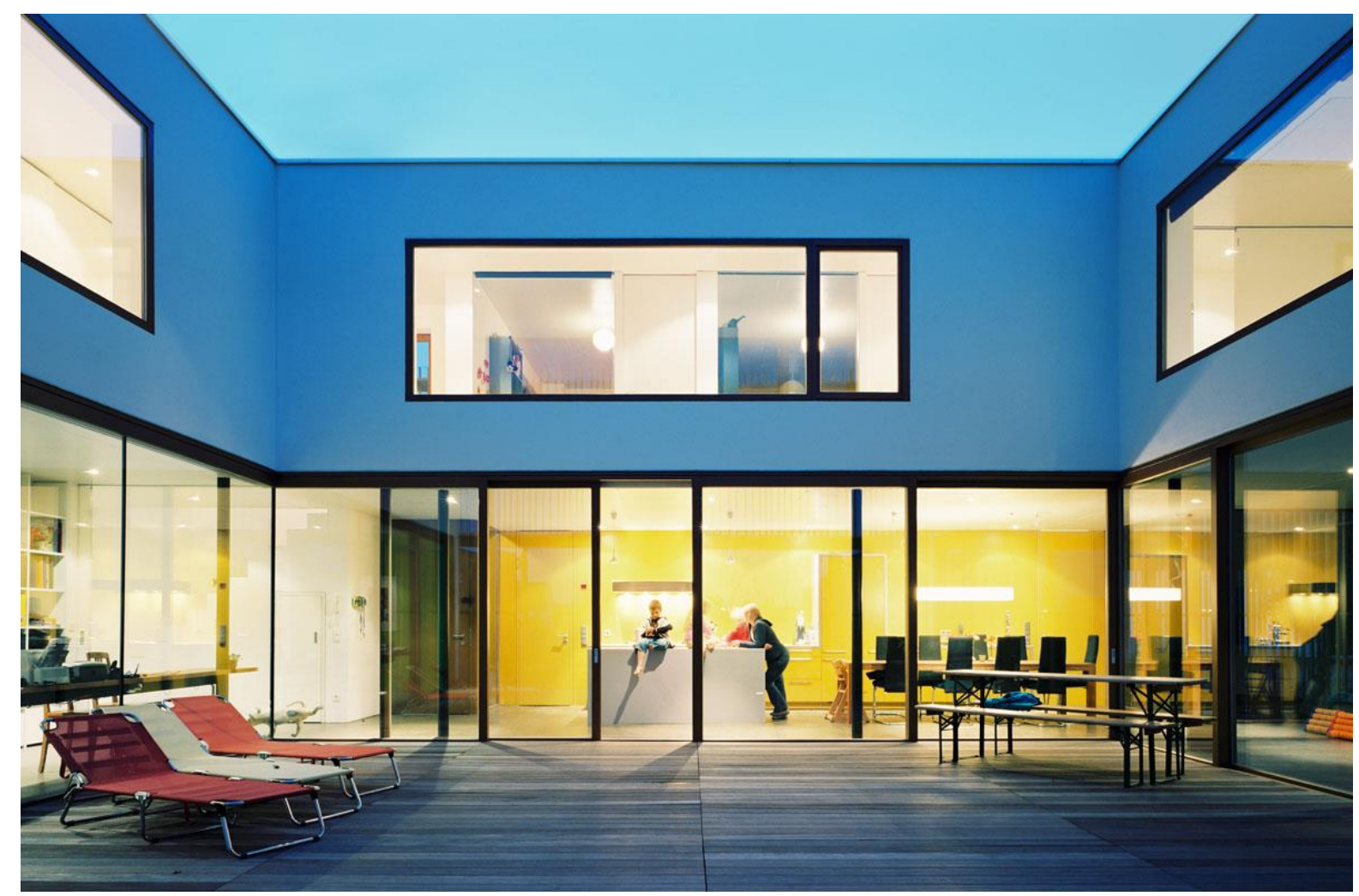

сл. 5 - House X, Nürnberg

\subsection{3 Социјална структура}

Домувањето е одраз и израз на комплексната социјална матрица. Во однос на социјалните системи се диференцираат и моделите на домувањето: индивидуално, колективно и мешовито.

Предмет на истражувањето е индивидуалното домување во типологијата на ниските станбени структури, како модели на домување кои овозможуваат истовремено поголеми социјални интеракции и кохезија кај корисниците и овозможува постигнување на висока урбана густина на населеност на градот.

Индивидуалното домување подразбира дека функциите на домувањето се диференцирани во однос на поединечни домаќинства/ станбени единици: едносемејни и повеќесемејни. 

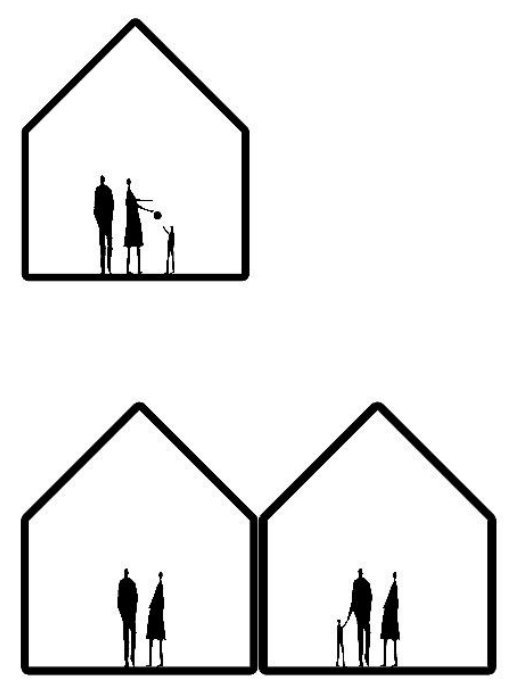

ЕДНОСЕМЕJHO

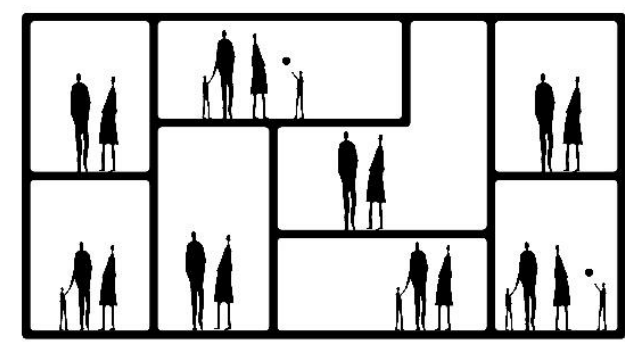

ПOBEḰECEMEJHO

сл.6 - индивидуално домување, социолошки пресек

Кристофрер Александер во својата книга “А pattern language”, создава јазик кој го нарекува "шематски јазик" кој произлегува од безвременските ентитети наречени шеми (патерни). Во делото се обработени теми од архитектурата, урбаниот дизајн и живоста на заедницата. Сите 253 патерни заедно формираат јазик. Патерните опишуваат проблем и потоа нудат решение за истиот.

Патерните се подредени почнувајќи од најголемиот, за региони и градови, потоа соседства, станбени кластери, градби, соби, финално завршувајќи со детали на конструкција. ${ }^{14}$ Секој од патерните е поврзан за одреден “поголем патерн” кој се наоѓa погоре во јазикот; и до одредени "помали" патерни кои се наоѓаат подолу во јазикот. На кратко, ниту еден патерн не е изолиран ентитет. Секој од патерните може да постои во светот, само до степенот до кој е поддржан од друг патерн: поголемите патерни во кои е вграден, патерните од истата големина кој го опкружуваат, и помалите патерни кои се состојат во нив. ${ }^{15}$

Станбениот пејсаж го формира социјалниот пејсаж составен од заедницата која е формирана од соседството, формирано од групите формирани од семејстватапоединечни патерни чија дефиниција е меѓузависна.

Патернот што го разгледуваме дава витални информации за социјалниот карактер на домаќинството.

Хипотеза: Нуклеарното семејство само по себе не е остварлива социјална фрорма. До пред неколку години, општеството се базирало на проширената фрамилија: фамилија од нејмалку три генерации, со родители, деца, баба и дедо, чичковци и

\footnotetext{
${ }^{14}$ Alexander, Christopher, "A Pattern Language, Towns, Buildings, Construction”, 1977, стр. хіi

${ }^{15}$ Alexander, Christopher, "A Pattern Language, Towns, Buildings, Construction”, 1977, стр. xiii
} 
тетки, братучеди, сите живеејќи заедно во едно домаќинство. Но, денес, луѓето се преселуваат стотици милји за да стапат во брак, во потрага по образование и работа. Под овие услови, единствените фамилијарни единици кои се останати се оние кои се нарекуваат нуклеарно семејство: родители и деца. И многу од овие се распаднати понатаму со развод или раделба.

За жал, изгледа како нуклеарното семејство да не е остварлива социјална форма. Премногу е мало. Секој од членовите на нуклеарното семејство е премногу тесно поврзано со другите членови на семејството; било која од овие односи да се тргне во погрешна насока, макар и за неколку часа, станува критично; членовите не можат да се осврнат кон чичковците, тетките, внуците, братучедитем браќата. Наместо тоа , секоја потешкотија ја носи кон потесна спирала на непријатност; децата стануваат плен на сите видови зависности и едиповски неврози; родителите се толку зависни едни од други што подоцна се приморани да се разделат. ${ }^{16}$

Физички, поставеноста за голема фамилија мора да го обезбеди балансот помеѓу приватноста и заедништвото. Секоја мала фрамилија, секој човек, секој пар, има потреба од приватен домен, скоро приватно домаќинство, соодветно со територијалните потреби. Во движењето на формирање комуни, во наше искуство е дека групите, оваа потреба за приватност ја немаат сфатено доволно сериозно. Одложено е како нешто што би требало да се надмине. Но тоа е длабока и основна потреба; и доколку поставеноста не дозволува секому и сечие мало домаќинство да се регулира себе во својата димензија, со сигурност се предизвикува невоља. Затоа, предлагаме, индивидуите, паровите, помладите и повозрасните- секоја подгрупа- да има свој легално независно домаќинство- во некои случаи, физички одвоено домаќинство, во најмала рака поединечни соби, апартмани и катови.

Приватните домени се поставени наспроти заедничките простори и заедничките фрункции. Највиталниот заеднички простор е кујната, местото за седење и јадење и градината. Заедничките оброци, најмалку неколку ноќи во неделата, изгледа дека ја имаат најголемата улога во врзувањето на групата. Оброците и времето поминато за готвење , овозможуват лежерно време на средба кога се́ друго може да се дискутира: начинот на грижа за децата, одржување, проекти. ${ }^{17}$

Овие погледи предлагаат дека покрај обезбедување на поединечни приватни домени, треба да се обезбедат и соодветно поставени заеднички простори каде членовите на семејството заедно ќе поминуваат лежерно време.

Заедничкото домакинство од 8 до 12 члена во хибридно колективно домување претпоставува морфологија на приватни домени за групи или индивидуи кои ја формираат пошироката фрамилија: домен на пар, приватни соби, под-домаќинства за мали фрамилии; заеднички простор за заеднички функции: готвење, работа, градинарство, грижа за децата; на важните крстосници на локацијата, место каде целата група ќе се сретнува и ќе поминува време заедно. ${ }^{18}$

\footnotetext{
${ }^{16}$ Alexander, Christopher, "A Pattern Language, Towns, Buildings, Construction”, 1977, стр. 377

${ }^{17}$ Alexander, Christopher, "A Pattern Language, Towns, Buildings, Construction”, 1977, стр. 379

${ }^{18}$ Alexander, Christopher, "A Pattern Language, Towns, Buildings, Construction”, 1977, стр. 380
} 


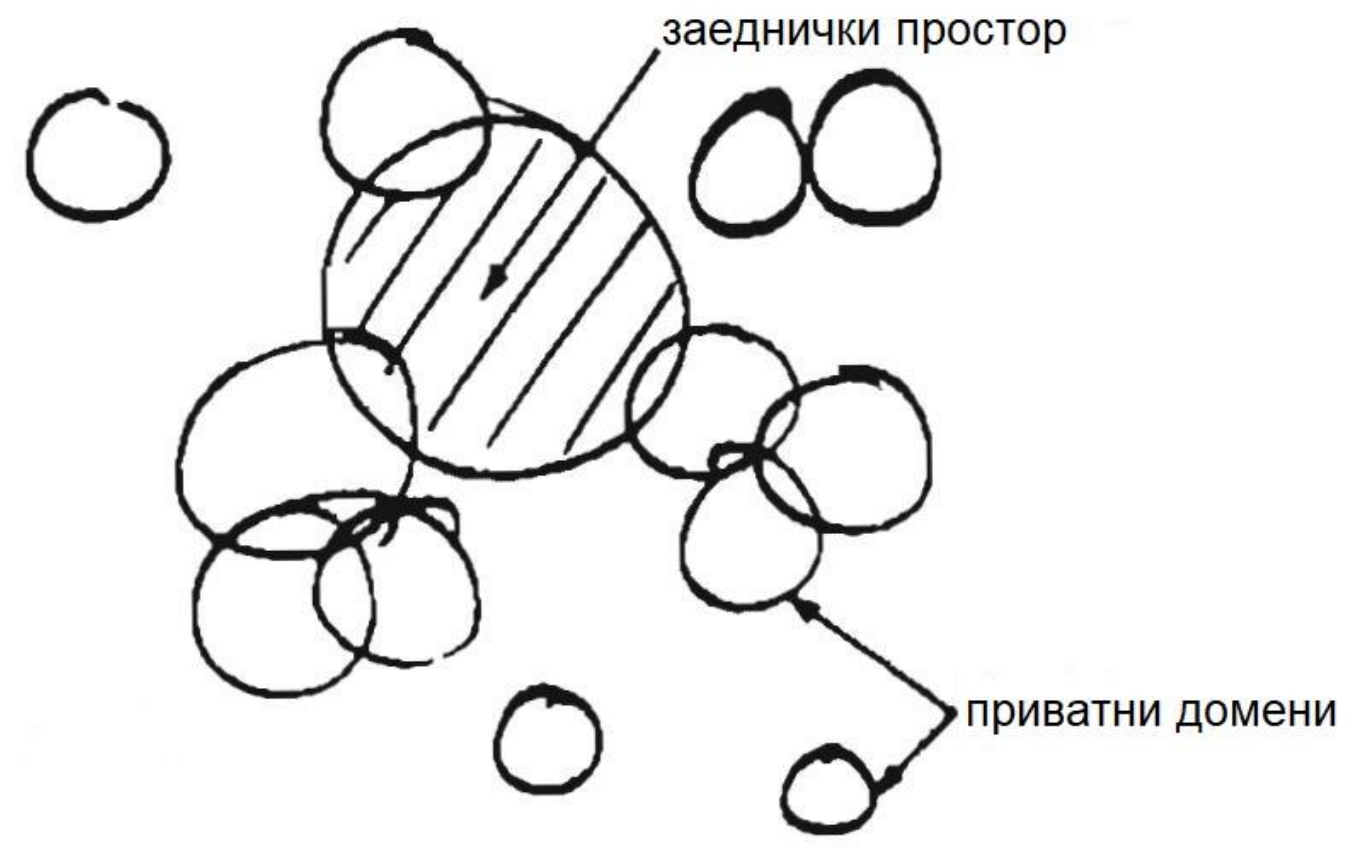

сл.7 - заеднички простор за социјализација на едно соседство

Во куќа за мало семејство, односите помеѓу децата и возрасните се најкритични. Затоа куќата треба да содржи дистинктивни делови: домен за родителите, домен за децата и заеднички простор. Овие домени треба да бидат слични во својата големина, со најголем дел за заедничкиот простор. ${ }^{19}$

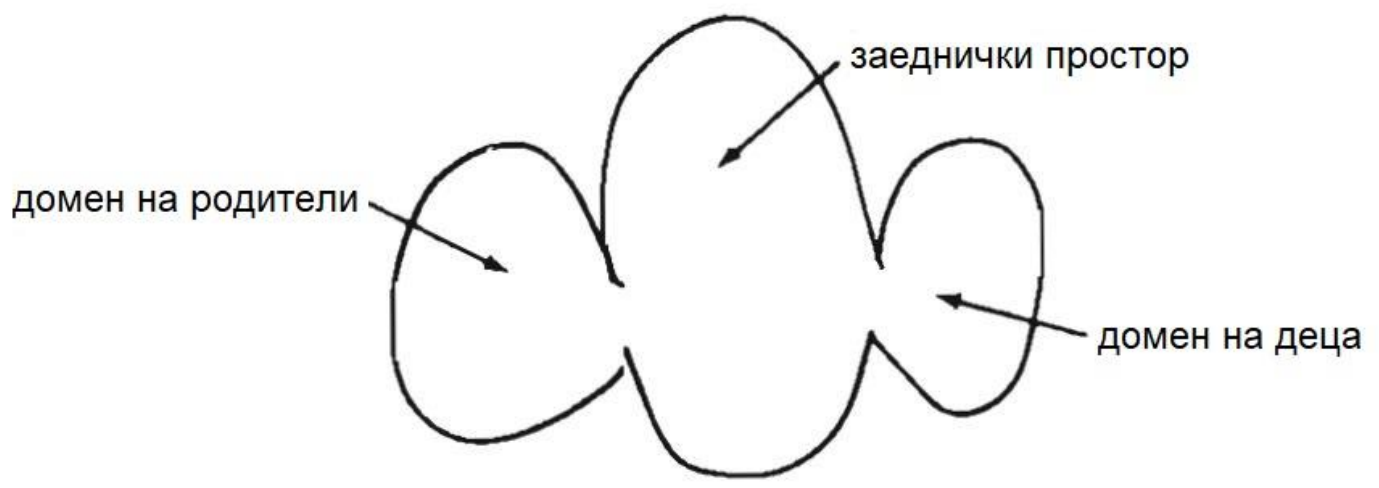

сл.8 - заеднички простор за споделување на ниво на семејство

Во мало домаќинство за двајца, најважниот предизвик кој се јавува е можноста дека секој од нив може да има мали можности за самотија и приватност. Куќата за пар треба да се осмисли како да е составена од два вида на простори- заеднички домен за парот и индивидуални приватни светови. Заедничкиот домен треба да биде замислен како полу-јавен и полу- интимен; и приватните светови како целосно индивидуални и приватни. ${ }^{20}$

\footnotetext{
${ }^{19}$ Alexander, Christopher, “A Pattern Language, Towns, Buildings, Construction”, 1977, стр. 384

${ }^{20}$ Alexander, Christopher, "A Pattern Language, Towns, Buildings, Construction”, 1977, стр. 387
} 


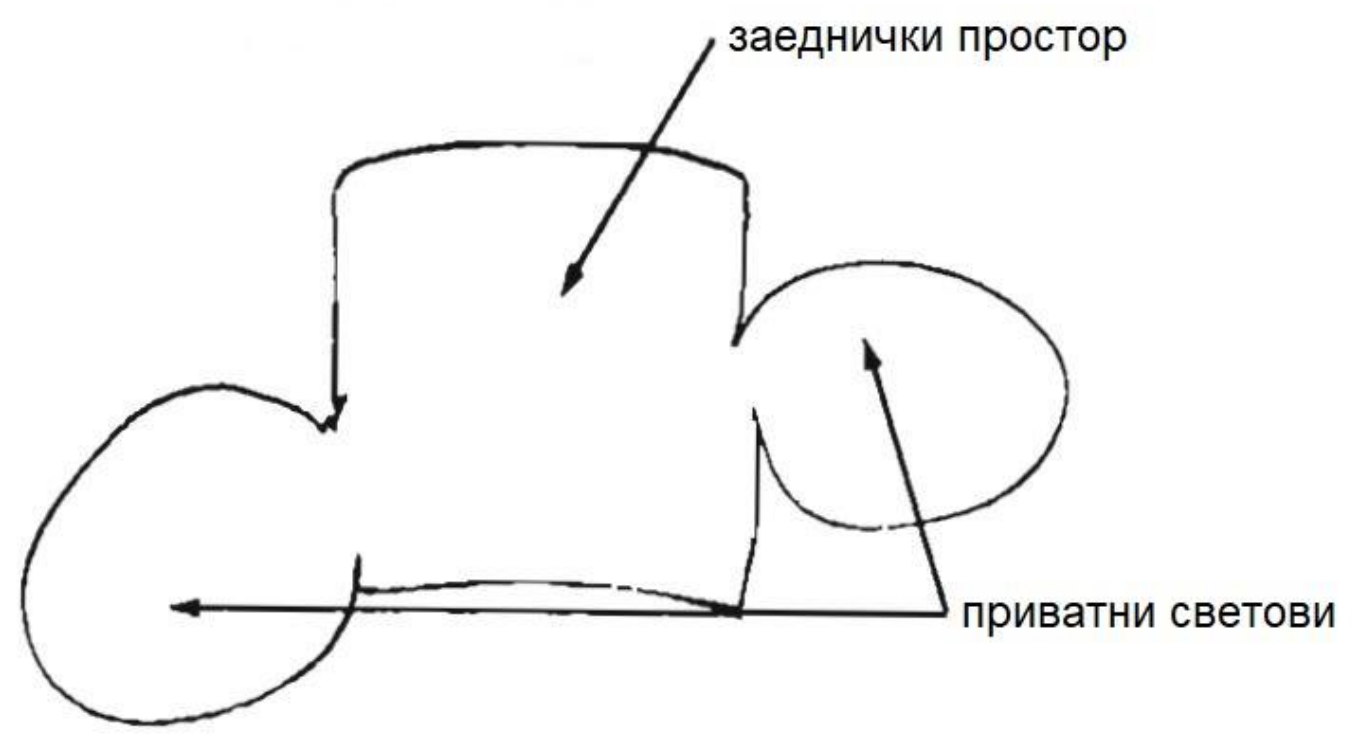

сл.9 - заеднички простор за споделување на ниво на пар

Кога домаќинство за еден човек е дел од поголема група, најкритичниот проблем кој се појавува е потребата за едноставност. Треба да се осмисли куќа за еден човек со најголема едноставност: всушност еднособна колиба или студио со големи и мали ниши околу неа. Целата куќа може да биде не повеќе од 27-37m². ${ }^{21}$

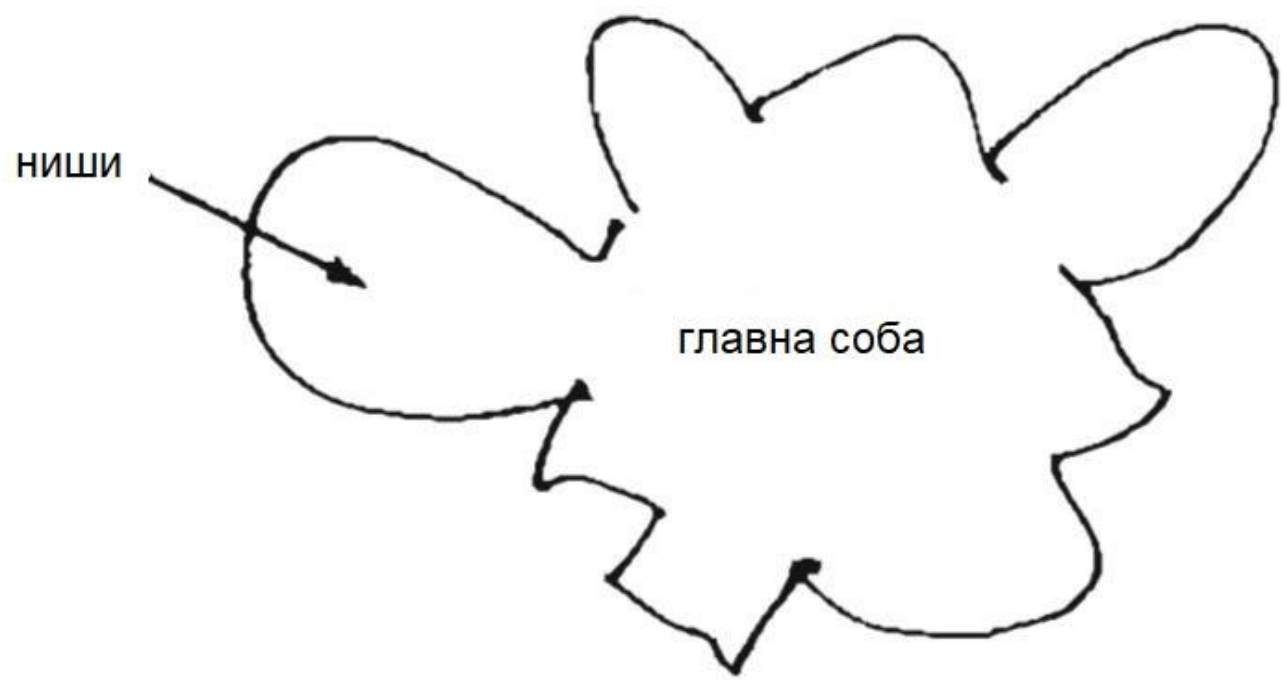

сл.10 - ниши- соби, ниво на приватен домен на домување на корисник

Станбениот пејсаж го формира социјалниот пејсаж составен од заедницата која е фрормирана од соседството, фрормирано од групите формирани од семејстватапоединечни патерни чија дефиниција е меѓузависна.

${ }^{21}$ Alexander, Christopher, "A Pattern Language, Towns, Buildings, Construction”, 1977, стр. 391 


\section{2. ИСТОРИСКИ И СОВРЕМЕНИ ПРИМЕРИ ДОМУВАЊЕ СО КАРАКТЕРИСТИКИ НА ГУСТО ИЗГРАДЕНА НИСКА СТАНБЕНА СТРУКТУРА}

\section{1. Историски увид во урбаното домување}

За да може да се зборува за квалитетот на домувањето во пооделни типови на станбени објекти потребно е да се познава генезата на престојувалиштето на човекот воопшто, неговиот развој и настанатите преобразби низ времето и просторот. Историјата на станбените форми всушност е комплексна историја на преобразбата на архитектонските идеи кои што треба да се адаптираат на општествените закони и стремежи, обичаите и начинот на живеење. Со самото истражување на развојот на формите, балансот меѓу куќата и градот, индивидуалното и заедничкото, семејството и општеството, овозможува да се осознае движењето и развитокот на станбената архитектура, потенцијал потребен за ревитализација на станбените форми или настанок на нови типови на урбано живеење.

Развојот на станбените форми е во целост поврзано со развојот на градот, а станбената архитектура претставува урбан, колективен феномен. Со сигурност може да се каже, дека основен модел на човековото живеалиште, врз кој што почиваат сите понатамошни настојувања во развојот на архитектонската мисла и градителство претставува рустикалната колиба. Борбата на човекот да го направи својот живот подобар и поудобен, следејќи ги хуманите и естетските настојувања, го навраќала кон природата барајќи ги мотивите во нејзините закони.

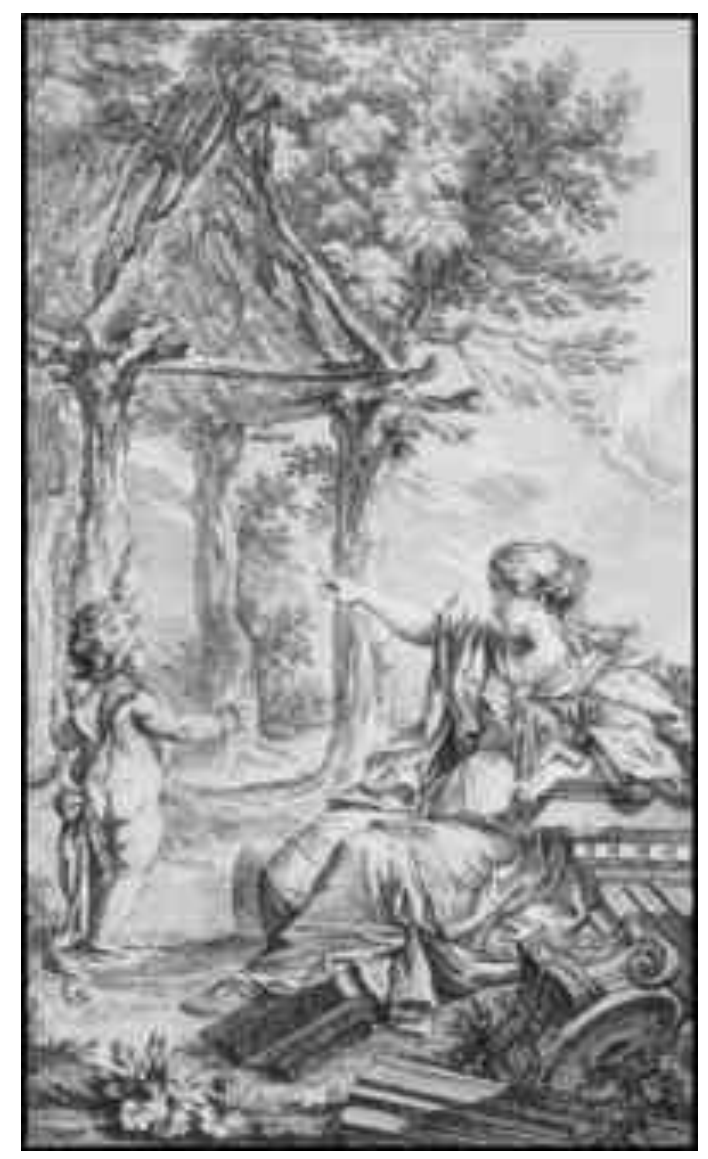

сл. 11 - Рустикална колиба, Laugier

Во грчките градови-држави делот на приватниот живот на граѓанинот е целосно поврзан со куќниот имот. Станбената куќа била надвор од интересите на 
архитектурата. Единствен примерок на домувањето во стара Грција претставува атриумското домување, водено од биолошките потреби за одржување и градено на законите за ефикасна природна организација на животот на имотот. За разлика од грчкиот град, римскиот претставува богатство на архитектонски идеи и станбени фрорми. Како врвен продукт на идеализмот на римската урбана култура, врз база на агрикултурната традиција на Италија и ехото на елинистичките палати се јавила вилата.

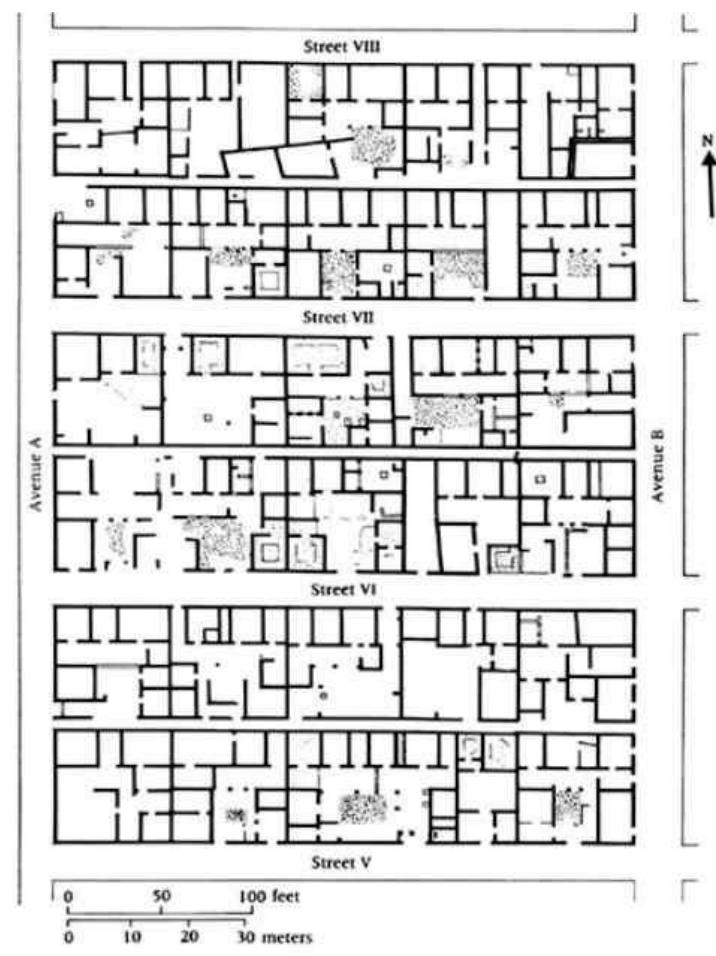

сл. 12 - Станбени атриумски низи, Olyntus

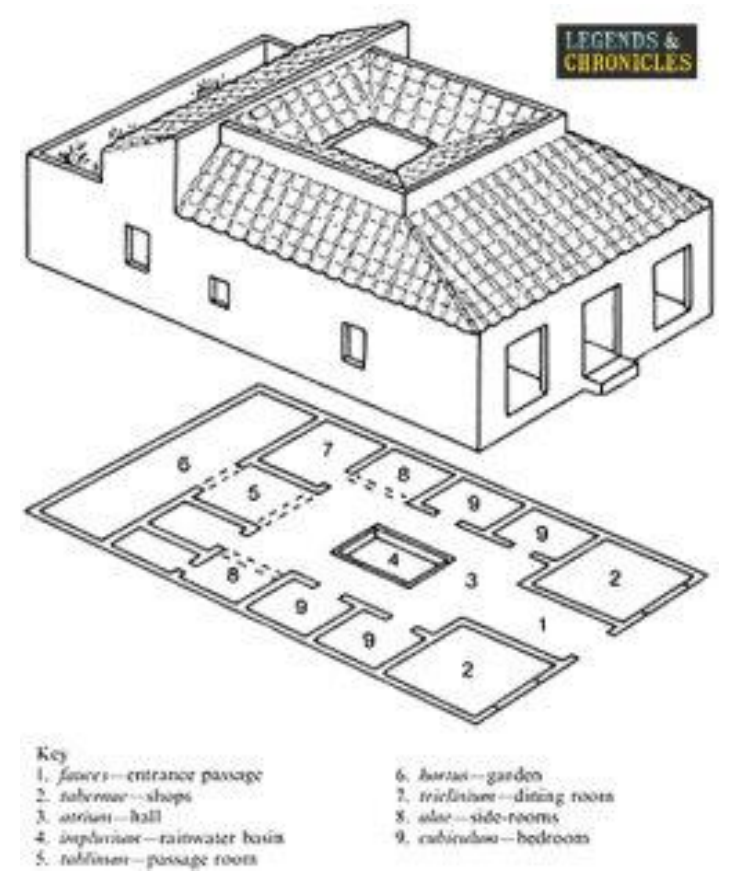

Сл. 13 - Атриумска куќa, Roman Domus

Во средновековниот град, парцелата ја изгубила дотогашната вредност во корист на куќата поради ограничената површина на градот. Приватното подрачје на куќата е 
целосно во служба на колективниот живот. Еднообразноста на индивидуалната куќа во својата целосно рационална внатрешна организација се јавува како спротивност на јавните репрезентативни простори на градот.

Ренесансниот град претставува центар на уметноста, науката и фрилозофијата. Во тој период кај човекот се јавил мит на природното домување, како последица од желбата за бегство од стегите на средновековното живеење и обичаи. Античката тема на фузија со природата добива вистинско значење на превласт на паркот над архитектурата. Вилата како намена, претставува идеално рурално прибежиште на богатите граѓани, но и архитектонски модел со неограничена примена.

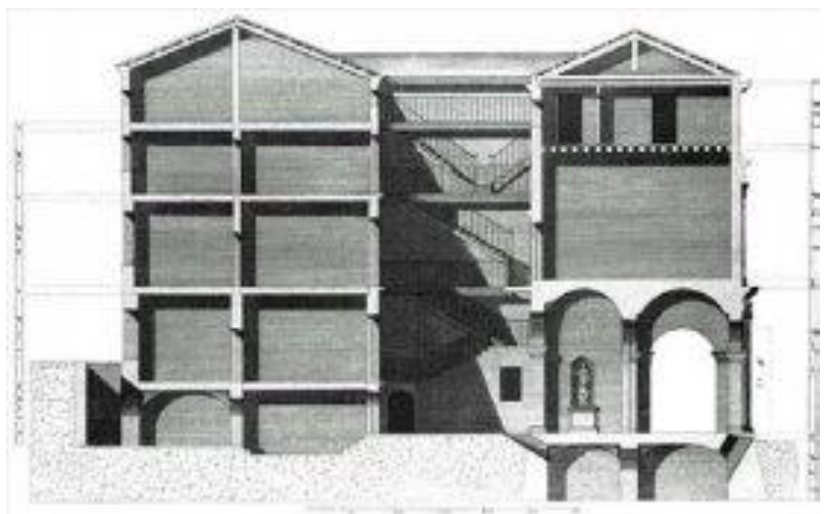

сл. 14 - Атриумска низа, Casa Cogolio, Vicenza, A. Paladio, 1776

Вилите во барокот и даваат нов статус на архитектурата изразен преку настојувањето, градот и околината да се потчинат на апсолутен, формален ред. Поради недостаток на простор ниските станбени објекти се развиле во височина.

Bo XVIII-тиот век се создава митот на природно домување, што ќе овозможи идеални услови за егзистенција на природниот човек одвоен од сите културни и социјални загадувања. Од една страна буржоаската вила развива нов станбен тип, користејќи го естетскиот аспект на природниот мит, додека комунитарната идеологија изградува утописки, социјални модели на домување врз силата на неговиот етички аргумент. И двете станбени фрорми својата легитимност ја наоѓаат во подрачјето на природата, далеку од урбаниот живот.

Во XIX-тиот век градот се проширува надвор од тврдините со што индивидуалното домување ги губи своите некогашни урбани белези и манифестира облици на социјално раслојување - буржоаска вила и наемна мала семејна куќа.

„Типот на малата семејна куќа станува архитектонска тема, посебно преку англиската "cottage" традиција и "Arts and Crafts", особено после возобновувањето на Ховардовиот Град градина 1902 година. Иако градовите- градини никогаш не биле замислени како населби на индивидуални слободни куќи, туку во прв ред алудирале на богатата континуирана англиска резиденцијална традиција row и terrace типови, сепак неговите планерски претпоставки многу добро ја асимилираат и конвенционалната станбена куќа“. Архитектонскиот пристап на семејната куќа е врзан за митската идеја на интимност, природност и сликовитост.

Во модерната архитектура проблемот на малата куќа е сведен на проблем на рационална основа во стеснети просторни услови и стандардизирање на индустриски произведените градежни елементи. Проектот на „новото домување“ бил централна тема на модерната архитектура. Павиљонот „De l'esprit Nouveau“ од Ле Корбизие го подигна овој нов интерес на ниво на монументален дидактички симбол. Станбените 
објекти добиваат нова монументална конотација.

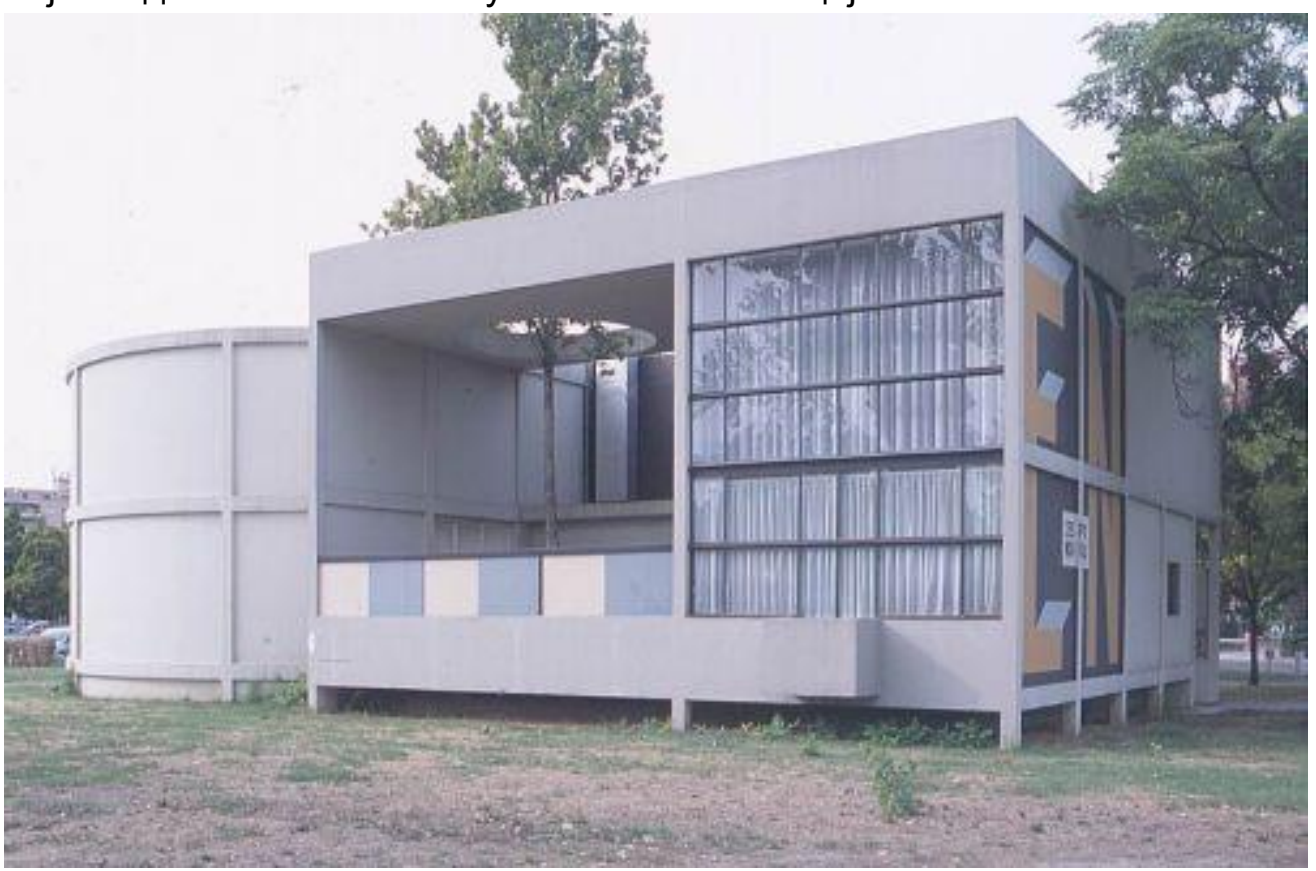

сл. 15 - Павиљон, De l'espirit Nouveau, Ле Корбизие, 1925

\section{2 Едносемејно домување на примерот на Скопје низ времето}

До крајот на XIX век концептот на живеалиштето во градските населби може да се проследи преку основните типови на едноделната наједноставна основа, дводелната и троделната основа и нивниот развој. Овие ограничени просторни единици не гарантираат удобно живеење на повеќегенерациско семејство. Меѓутоа еволуцијата на основата како и растењето на куќата во вертикален правец овозможуваат подобрување на условите за живеење на старите луѓе во семејството.

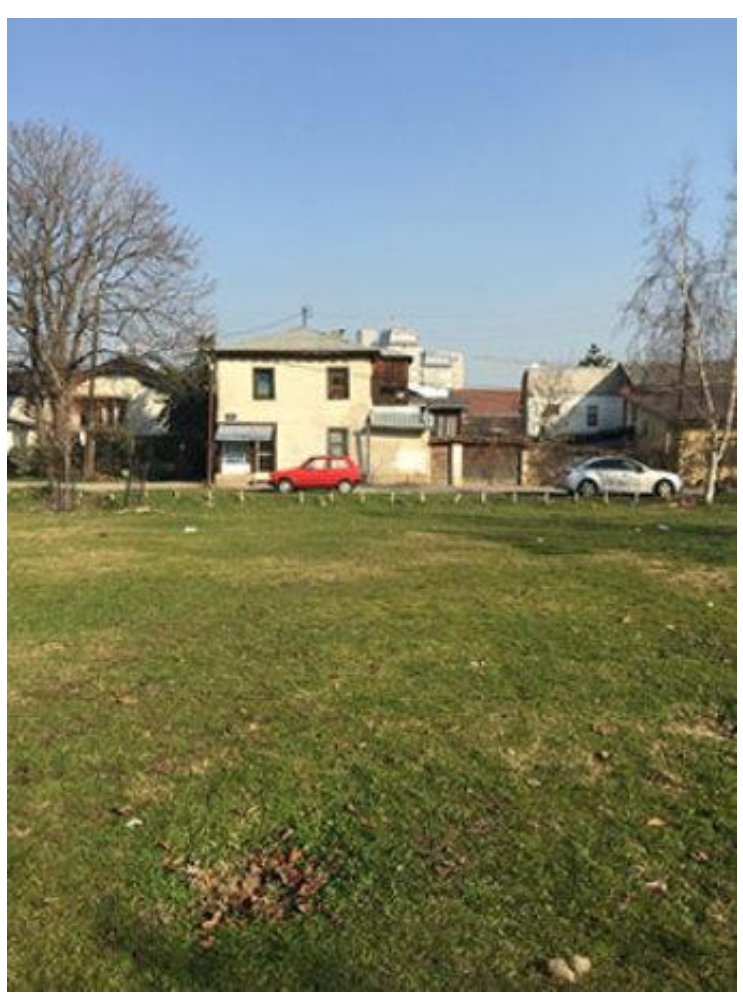

сл. 16 - Улична линија на едносемејни куќи, ул. “Истарска”, Ново Маало, Скопје 


\subsection{1 Период меѓу двете светски војни}

Борбата за опстанок на патријахалното семејство во традиционалното живеалиште е забележително во почетокот на XX век, кога во западна Европа градовите се задушени со проблемите на капитализмот, а во македонските градови сеуште се живее во феудални односи. Поседувањето на сопствена парцела кај семејната куќа е актуелна и во денешно време, иако концептот на традиционалното живеалиште се видоизменува во согласност со изменетите стопански и општествени прилики.

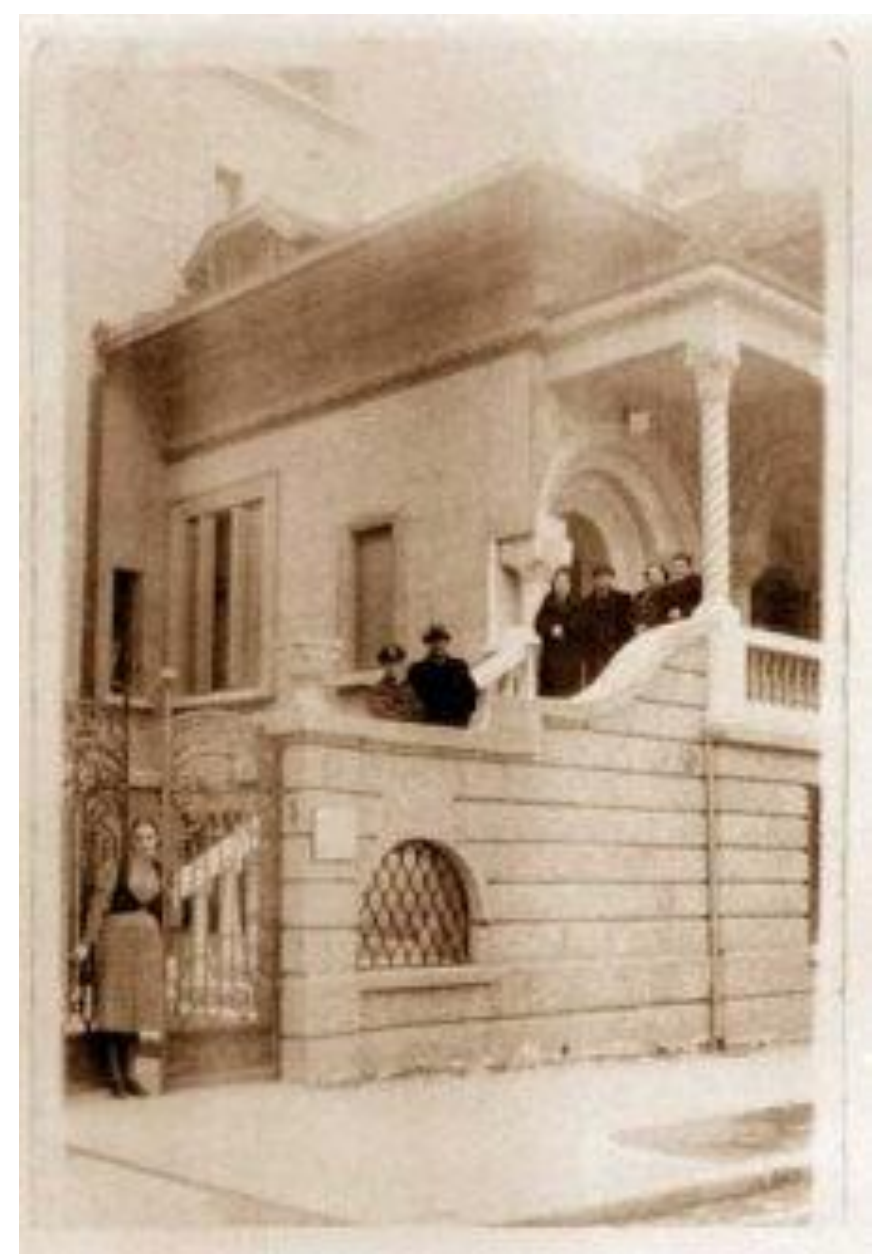

сл. 17 - Куќата на семејството Шкаперда, архитект Георги Симота, Скопје, 1939 год.

Пример на организирана изградба на станови за работници во Скопје е Железничката колонија од 1929 година. Семејните куќи во рамките на овој потфат претставуваат прва појава на современа станбена низа со правилна парцелација на локацијата. Секоја ламела од низата има преден и заден двор што претставува карактеристика на неурбаната типологија (периферија на град). Самиот објект со неговата скромна содржина зборува дека е наменет за работничко семејство. Овие станови обезбедуваат минимален просторен комфор збогатен со квалитетите на отворените дворни површини. 


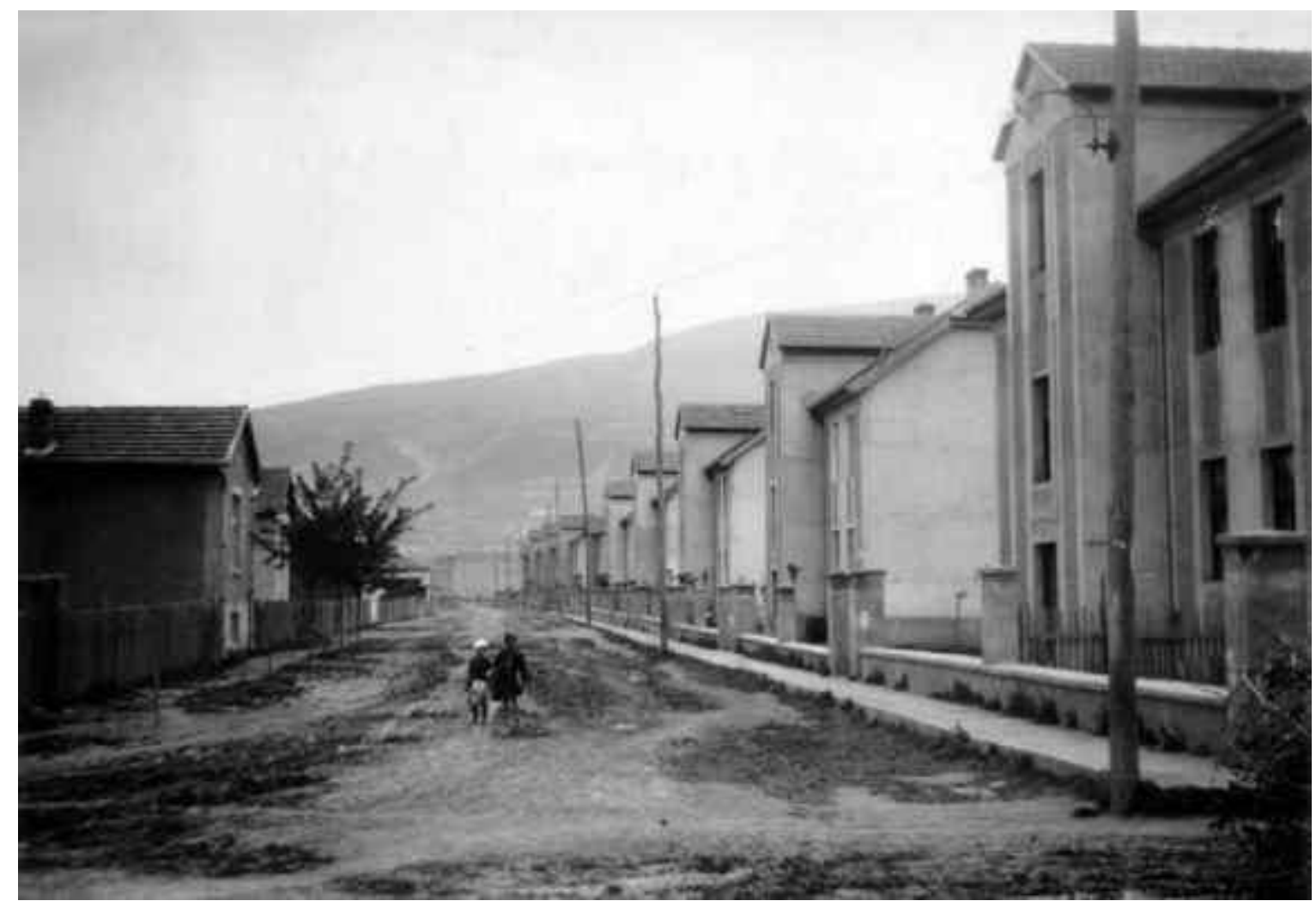

сл.18 - Железничка колонија, Скопје, 1929

Овој период од минатиот век се карактеризира и со изградба на куќи за рента, куќи од европски тип кај кои што се губи традиционалното живеалиште. Тоа се куќи со повеќе семејни станови. Во овој период се забележува интензивна станбена изградба на едносемејни куќи кои што биле градени со сутерен и високо приземје или приземје и кат. Урбаната типологија на куќите се одликувала со ивична изградба на улиците. Овој вид на поставување формирало приватен двор зад куќата. Земајќи го примерот за градење од европската куќа, концентрацијата на станот се базирал на централно поставена просторија - салон во еден тип на куќи или проширена комуникација во друг тип на куќи, директно поврзани со другите соби и економскиот дел на куќата. Во многу случаи поразвиената економска група на простории имала директна врска со дворот која во одредени случаи можела да служи како помошен влез (населба Буњаковец). Во зависност од големината на куќата и нејзината содржина, истата овозможувала живеење на тригенерациски семејства. Автономноста на делот за живеење на старите луѓе се сведувала во поседувањето на сопствена соба.

\subsection{2 Период после втората светска војна}

По втората светска војна со развојот на трговијата, индустријата и занаетчиството биле потикнати миграциите на селското население во градовите што го актуелизира решавањето на станбениот проблем. Истиот се решавал под терминот обезбедување „покрив над глава“ т.е. сместување на голем број урбани емигранти во претежно супстандардни станови - период на рурализација на градовите. И покрај овој процес во овој период се градат едносемејните куќи „градските вили“ кои можеме да ги сретнеме во централното подрачје на Скопје. Посебно се значајни ремек делата на повоениот модернизам, делата на чешкиот модернист Лудјек Кубеш, што можеме да ги сретнеме долж улицата „Орце Николов“. 


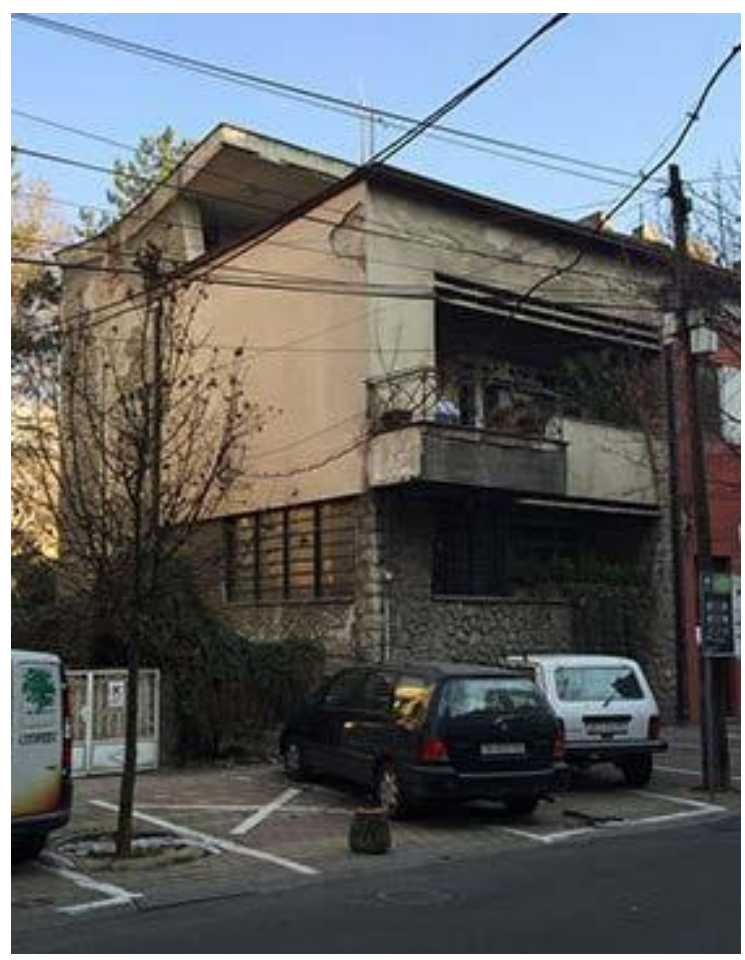

сл. 19 - Градска вила на ул. “Орце Николов”, архитект Лудјек Кубеш, Скопје, 1952 Фото: Минас Бакалчев

Слободностоечките поединечни куќи како предоминантни типови на современиот урбанизам не ја почитуваат основната претпоставка за постигнување на идентитетот на градските населби - историската повеќеслојност на фризичките и општествените структури. Современите населби ја губат урбаната атмосфера, амбиенталност и топлина, карактеристична за традиционалните населби. Во тоа време се случуваат промени настанати со разорувањето на патријахалното семејство и негово сведување на помал број на членови, кои што се одразуваат и на концептот на живеалиштето. Третата генерација ја губи повластената положба која ја имале во семејството, а со тоа и побарувачката на станови е со изменета структура, соодветна на изменетите потреби.

Од типот на семејните куќи во организираната станбена изградба по војната приоритетот е даден на изградба на двојни куќи. Овие куќи се наменети за сите социјални слоеви и рефлектирајќи го идеалот на семејниот живот на нив се гледа како радосни и комфорни места. Двојните куќи во овој период се речиси исти, типски, со вертикална диференцијација на на функциите за дневен и ноќен боравок. Дневната соба се ослободува целосно за одмор и разонода, ручањето се обавува во посебна просторија - трпезарија, а кујната е сместена во ниша (населба Пролет). Хигиенските услови за живеење се исто така подобрени со двоење на нужникот од бањата, која што сега е сместена со двете спални соби на катот. 


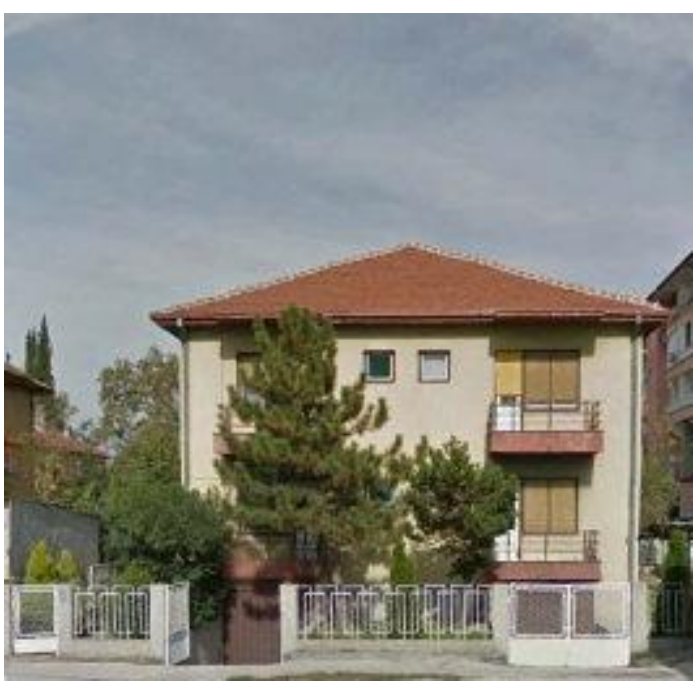

сл. 20 - Двојни куќи градени во периодот после втората светска војна, населба Мичурин, Скопје

Ваквите проектирани куќи овозможувале комфорно живеење на нуклеарно четиричлено семејство. Но, многу често, куќите од овој тип се населувани и од тригенерациски семејства. Во тој случај третата генерација обично спиеле во трпезаријата или дневната соба, каде што можело да се смести помошно легло, а некои уште при градењето вршеле адаптација на решението и ручањето го организирале во дневната соба, нишата за готвење заедно со обезбедениот влез од претсобјето преминувала во работна кујна, а трпезаријата ја пренаменувале во соба за старите родители. Куќите во овој период биле проектирани за новиот тип на семејство, кое што било на повидок, додека местото на старите родители во куќата не било ниту дефинирано ниту препознатливо. Секој пат кога во семејството имало и стари родители, организацијата на функциите како и комфорот на домувањето биле нарушени.

После земјотресот во 1963-тата година индивидуалното домување воглавно било застапено со изградба на монтажни семејни куќи, кои што немале битно влијание врз развојот на концепцијата на станот, но го забрзале решавањето на станбеното прашање, а воедно и значително го подобриле квалитетот на дотогашното домување во големиот број субстандардни станови, градени со слаб материјал и без основни санитарнохигиенски услови. Неурбаната типологија на изградба на приградските населби како и ограничениот век на траење на монтажните куќи (20-30 години) имале силно влијание врз денешниот развој и изглед на овие населби. Монтажните куќи биле претежно од типот на слободностоечки и двојни куќи, а по структура биле најразлични, од едноиполсобни до трисобни. Уривањето на живеалиштата на луѓето во земјотресот го потпомогна процесот на раслојување на повеќегенерациските семејства. Mеѓу тие што чекале решавање на станбеното прашање имало и голем број на старечки домаќинства. 


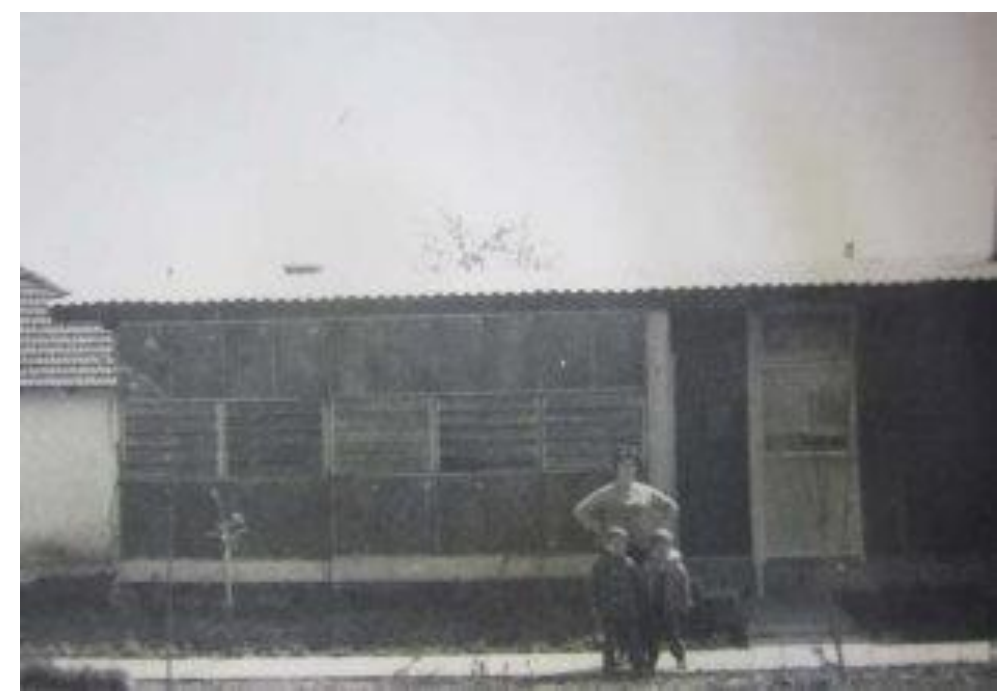

сл. 21 - Мексиканските бараки по проект на архитект Pedro Ramirez Vasquez, Тафталиџе, Скопје

Еден од типовите кои што биле соодветни за домаќинствата на третата генерација биле куќите од типот „Утва“ кои што биле според типот двојни и според структурата едноиполсобни. Непосредната поврзаност на терасите и влезовите на двата стана во овие куќи, позитивно се одразувале врз развивањето на добрососедските односии врз елеминирањето на чувството на осаменост и изолација, особено кај постарите лица. Поседувањето на сопствена слободна парцела (преден и заден двор) дава широки можности за корисно ангажирање на постарите лица и пријатно поминување на денот. Денес во овие домови живеат нови стари генерации, самечки или во проширени семејства, но во доста променети станбени услови.

Новиот концепт на живеалиштето беа поголемите површини на просториите за живеење, како и во подела на децата по полови во посебни простории (спални соби), со што на децата им се овозможува своите спални соби да ги третираат како сопствени простории за учење, игра и прием на пријатели. Од друга пак страна, во зависност од структурата на семејството едната од спалните соби секогаш може да се користи и од третата генерација. Во седумдесетите години, новите потреби на нараснатите семејства и изменетата структура, потикнаа проширување на просторот за живеење, во почетокот во вид на доградби, а во осумдесетите години и во вид на надградби се до целосно сменување на монтажните куќи со нови градби. Типот на семејните куќи и условите на локациите овозможуваа живеење на старите и младите во заедничка куќа, во посебни автономни станбени целини, што овозможува услови за развивање на пријатна семејна атмосфрера, блискост и сигурност. 


\section{3 Современи примери на едносемејно домување, групни форми}

\subsubsection{Adriaan Geuze, West 8, Borneo \& Sporenburg, Amsterdam 1993}

Локација: Амстердам

Архитект: Adrian Geuze, Wim Kloesterboer, Yusi Uehara, Sebastian Riquois

Изведувачи: New deal, Stichting B01, SFB, Smits Bouwbedrif, M.J. De Nijs, Private Проектирано: 1933

Изведено: 1955

Проектот е изработен како одговор на барањата на резиденцијалната акција со широк опфат - „Живеење на вода“, која што се однесувала на кејот на двата долги полуострови во големата амстердамска пристанишна област. Предлогот требало да покрие локација за 2500 станбени единици со густина од 100 претежно едносемејни објекти на еден хектар. Решението се состои од динамично повторување на еден апстрактен модел.

Во ова море од станбени единици издигани се три суперблокови: два со осум катови и еден наречен „стол“ од четиринаесет ката. Тие треба да обезбедат континуитет со опкружувањето создавајки визуелна врска и продолжение на „приказната“ почната уште од далеку.

90 метри широкиот Спорвег канал минува меѓу двата насипи. Два пешачки моста ги поврзуваат полуостровите на кои има две, централно поставени зелени површини, кои треба да го заменат отсуството на вода во средишниот дел со многу домови.

Становите во суперблоковите имаат стакленик и покриен балкон. Влезовите во останатите домови се од приземјата, што значи директен пристап од улица и од градината. Моделот кој е слободна интерпретација на традиционалната амстердамска куќа што излегува со еден фронт на каналот, внатрешен двор и додадени објекти во дворот, создава нова куќа со лентовидни дворови, кровни тераси и пред се е потфат со кој се истражуваат лавиринтите, како оние во касабите создадени од дворови и тераси.

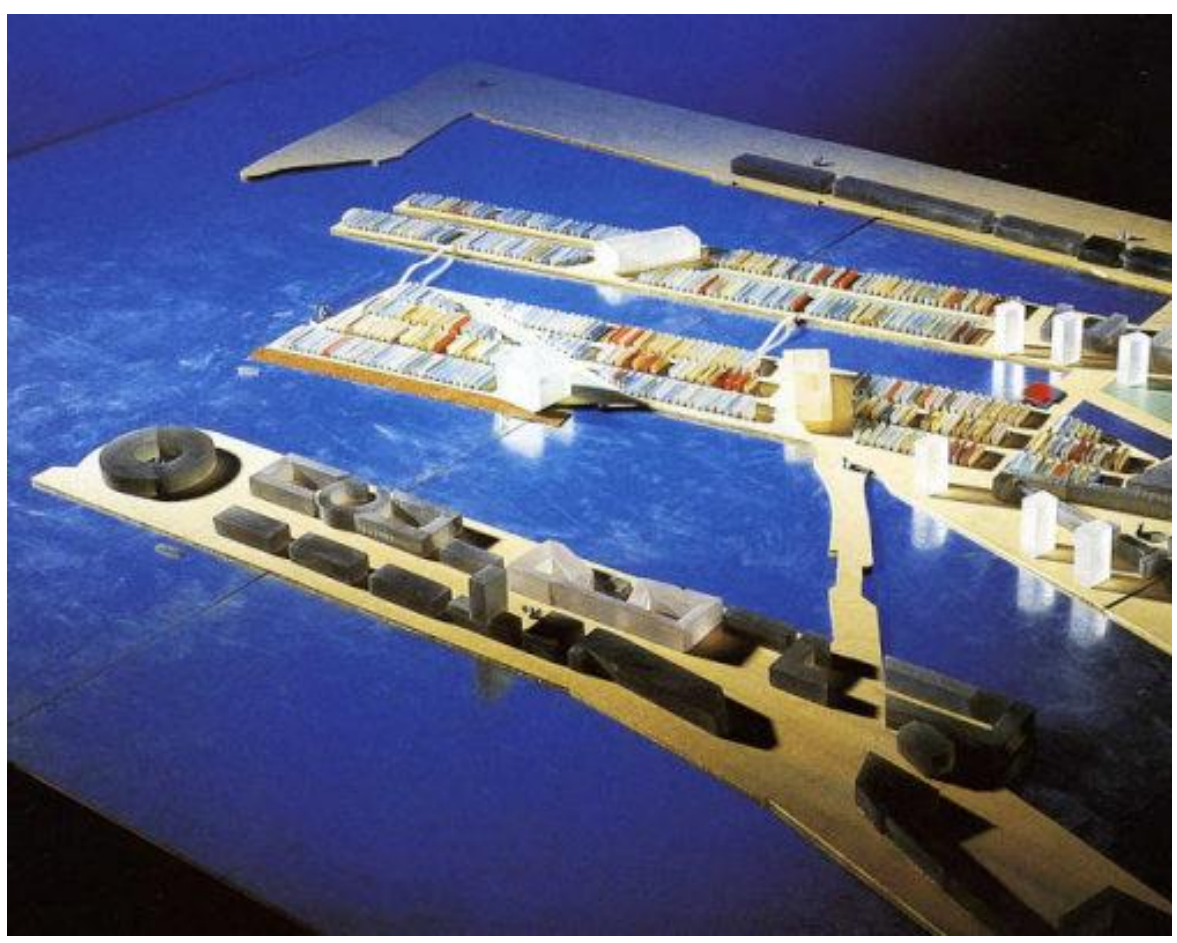

сл.22 - Просторен план на Borneo \& Sporenburg, Амстердам, 1933 


\subsubsection{Atelier 5, Halen Estate, Bern, Switzerland 1960}

Halen Estate, е каноничен прототип за ниска станбена структура со висока густина на домување во втората половина на XX век. Оваа заедница од 79 каскадни куќи изградени на ридест терен ориентиран кој југ во предградието на градот Берн ги инкорпорира многу од идеите на модерната од 1920 за заедницата и приватноста, идејата за градот- градина и здрав животен и ставови за материјали и стандардизација.

Halen е дизајниран од тим од 5 млади архитекти: Edwin Fritz, Rolf Hesterberg, Samuel Gerber, Hans Hostettler и Alfredo Pini.

Halen Estate ce карактеризира со отворени простори- централен плоштад, лонгитудинални пристапни улици, скалишни поврзувања, влезови на различни нивои и комуникации се ослободени од моторизиран сообраќај. Петте низи содржат 79 единици, главно засновани на два типа на тесни едносемејни куќи за индивидуално домување (4.2м /5.15м) на три нивои со двориште кон пристапниот пат, уреден како градина која е јужно ориентирана со наткриено седење на крајот. Делумно , двете куќи се со сончеви тераси на горниот спрат и имат поглед кон пејсажот. Куќите се конципирани со прогресија во просторот од јавен, до полу-јавен кон приватен простор. Широк опсег на заедничка опрема како базени, игралишта, простории за средби, продавница, перална, паркинг простори и греење се осмислени за колективен начин на живеење.

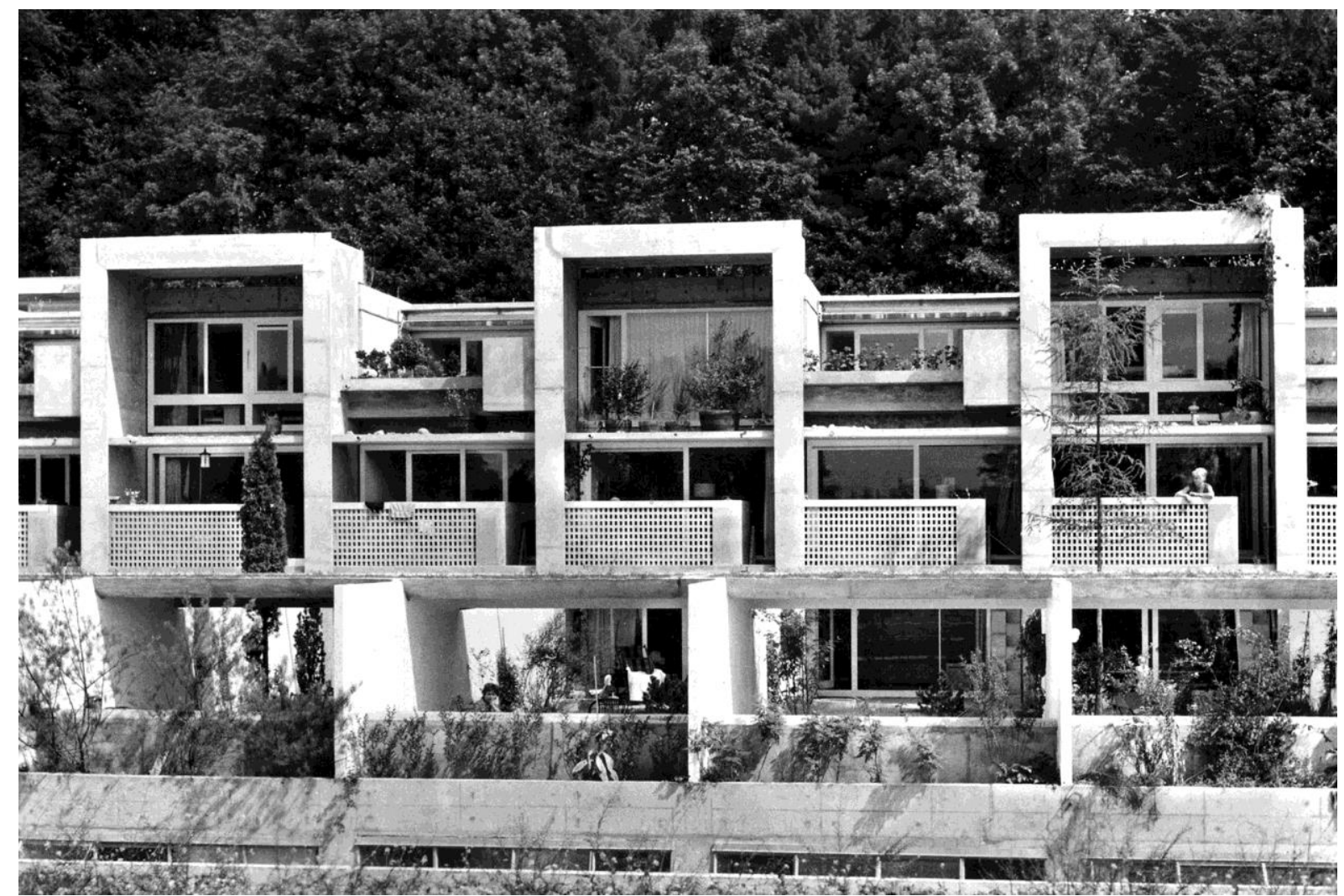

сл. 23 - Halen Estate, типологија на куќи во низа 


\section{3.ПРЕДЛОГ НА КОНЦЕПТ РЕШЕНИЕ НА НОВ СТАНБЕН КЛАСТЕР ОД ЕДНОСЕМЕЈНИ КУК์И ВО ДЕБАР МААЛО, СКОПЈЕ}

\section{1 Типоморфолошка анализа на просторниот контекст на локацијата}

Дебар Маало претставува скопска населба во состав на Општина Центар, од десната страна на реката Вардар. Дебар Маало се граничи со Центар, Тафталиџе I, Карпош I, Зоолошката градина и Градскиот парк.

Маалото настанало од прогонети Македонци од делови на Западна Македонија кои со сила биле раселени и своето ново место на живеење го нарекле според името на етнографрскиот предел од каде што потекнуваат.

Местото каде што било лоцирано ова маало било едно од поновите предградија на Скопје. Пред тоа, на ова место постоеле градини и ниви. Првите куќи биле подигнати во 1920 година од страната на Браќата Петар и Андреја Митровиќ и од Јован Поповиќ. Тие потекнувале од Голо Брдо, Дебарско, регион што по 1918 година припаднал на соседна Албанија. Спомнатите дебарчани во 1919 година се населиле во Скопје, каде што купиле плацеви и изградиле куќи на просторот на некогашното Дебар маало. Овој простор се́ уште не се сметал за градски, туку спаѓал во атарот на селото Долно Водно. Во 30-тите години на 20 век, по економската криза, во Дебар маало почнале да се доселуваат и жители од стариот дел на Скопје. Напуштањето на старите реони во Скопје било резултат на тешкиот економски живот.

Од Железничката колонија и Учителската школа, се́ до 1920 година, Дебар маало било одделено со празен простор што го населувале доселениците. Дебармаалците биле прочуени зидари. Овој занает се пренесувал од генерација на генерација. Ретко некој член од sидарска фрамилија се занимавал со друг занает. Жените во Дебар маало, освен вршењето на сите женски домашни работи, се занимавале со везење и на тој начин заработувале пари.

Дебар маало главно било населено со сиромашно население, но во него имало и „многу куќи на кат”, односно куќи на побогати семејства. Куќите во ова маало биле градени од тврд материјал и плитар, но со оглед дека биле градени според економските можности на секој доселеник, честопати биле дивоградби и без план. Внатрешното уредување на дебармаалските куќи било полуградско, а во некои фрамилии се спиело на под. Имале мебел кој со себе го донеле од старото место на живеење. Мебелот се состоел од кревети, ормани, маси, столови, отомани и слично.

Во Дебар Маало имало неколку дуќани од кои се снабдувало населението. Наброените дуќани, млекари, фурни и слично, служеле за задоволување на секојдневните потреби на дебармаалците, додека со сите други производи се снабдувале од градските пазари и дуќани во чаршијата и во градот. Со ваков начин на живот, жителите од ова маало постепено се вклопувале во градскиот живот.

Денес Дебар Маало претставува високоурбанизирана населба. Поради фрактот што се наоѓa во строгиот центар на јадрото на градот, населбата има доста високи цени на недвижнините. Дебар Маало е познато по боемскиот живот и денес тука се наоѓаат голем број на ресторани. ${ }^{22}$

\footnotetext{
${ }^{22}$ https://mk.wikipedia.org/wiki/Дебар-Маало
} 


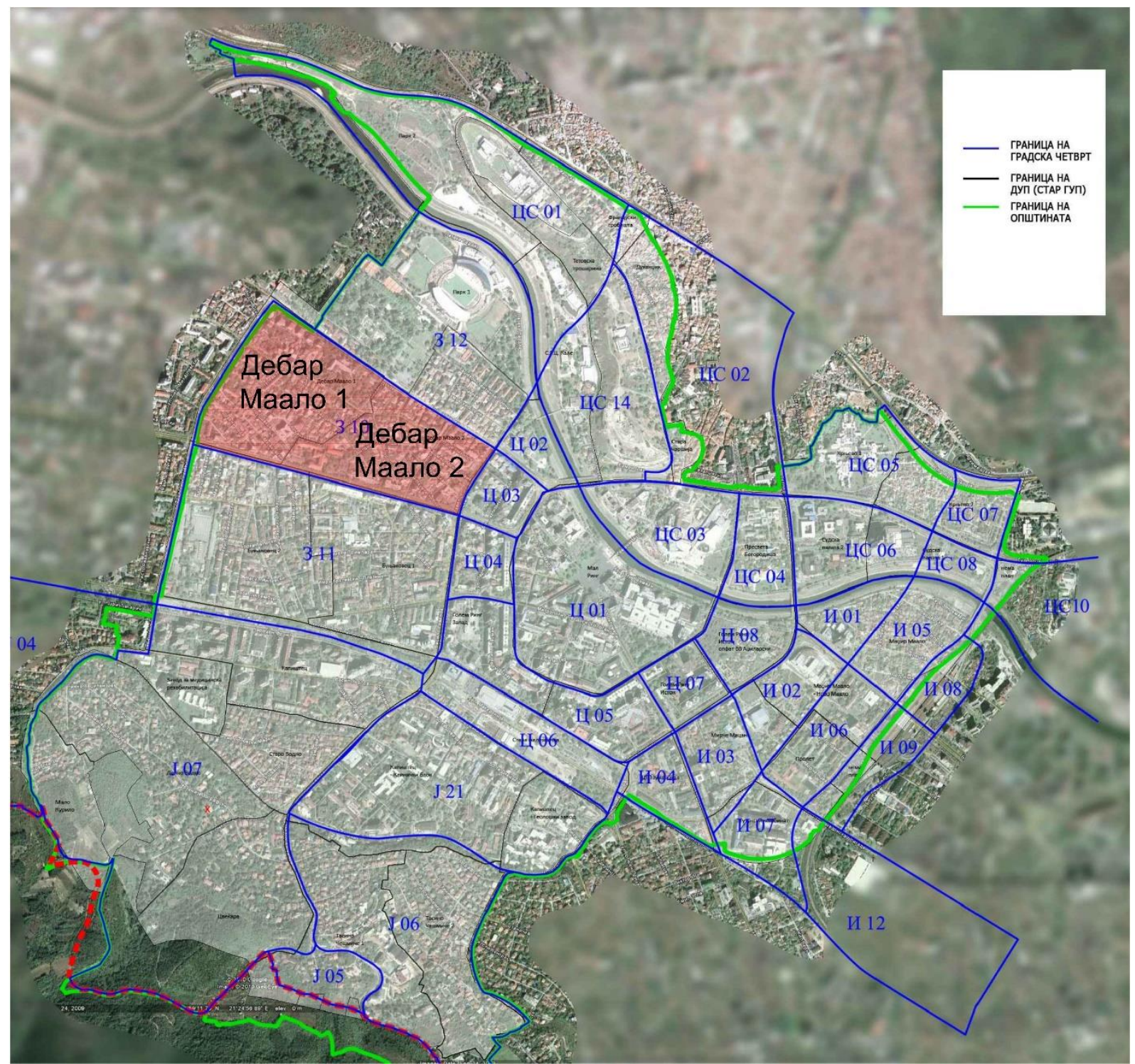

сл.24 - местоположба на Дебар Маало во Општина Центар, Скопје

Денес, градската четврт Дебар Маало претставува високоурбанизирана четврт и припаѓa на Општина Центар, јадрото на градот. Таа е поделена на западен дел- Дебар Маало 1 и источен дел- Дебар Маало 2. Дебар Маало граничи со: Општина Карпош на запад, Парк 1 (Градски парк) на север, Голем ринг запад на источната страна и со Градската четврт Буњаковец 1 и 2 на југ. Атрактивноста на оваа градска четврт е дефинирана од многубројните содржини во нејзината непосредна близина од различен тип. Покрај Градскиот парк, голема површина на зеленило која нуди рекреација и спортски активности (Градски Стадион) на граѓаните, до јавни институции (Министерство за одбрана, Град Скопје, Министерство за Култура, Општина Центар, Природнонаучен музеј), Архитектонски фракултет-Скопје, Библиотека Браќа Миладиновци, основни училишта (ОУ Јохан Хајнрих- Песталоци, ОУ Коле Неделковски), трговски центар Буњаковец, детска градинка 13ти Ноември, мали приватни галерии и угостителски објекти. 
Покрај сите овие содржини, во градската четврт Дебар Маало доминира типологијата домување во ниски (ендемска типологија) и средно- високи (доминантна типологија) станбени структури. Ноќната раздвиженост на оваа градска четврт се должи на многубројните угостителски објекти кои придаваат дополнителен квалитет во одос на начинот на живот на самите жители и сите посетители.

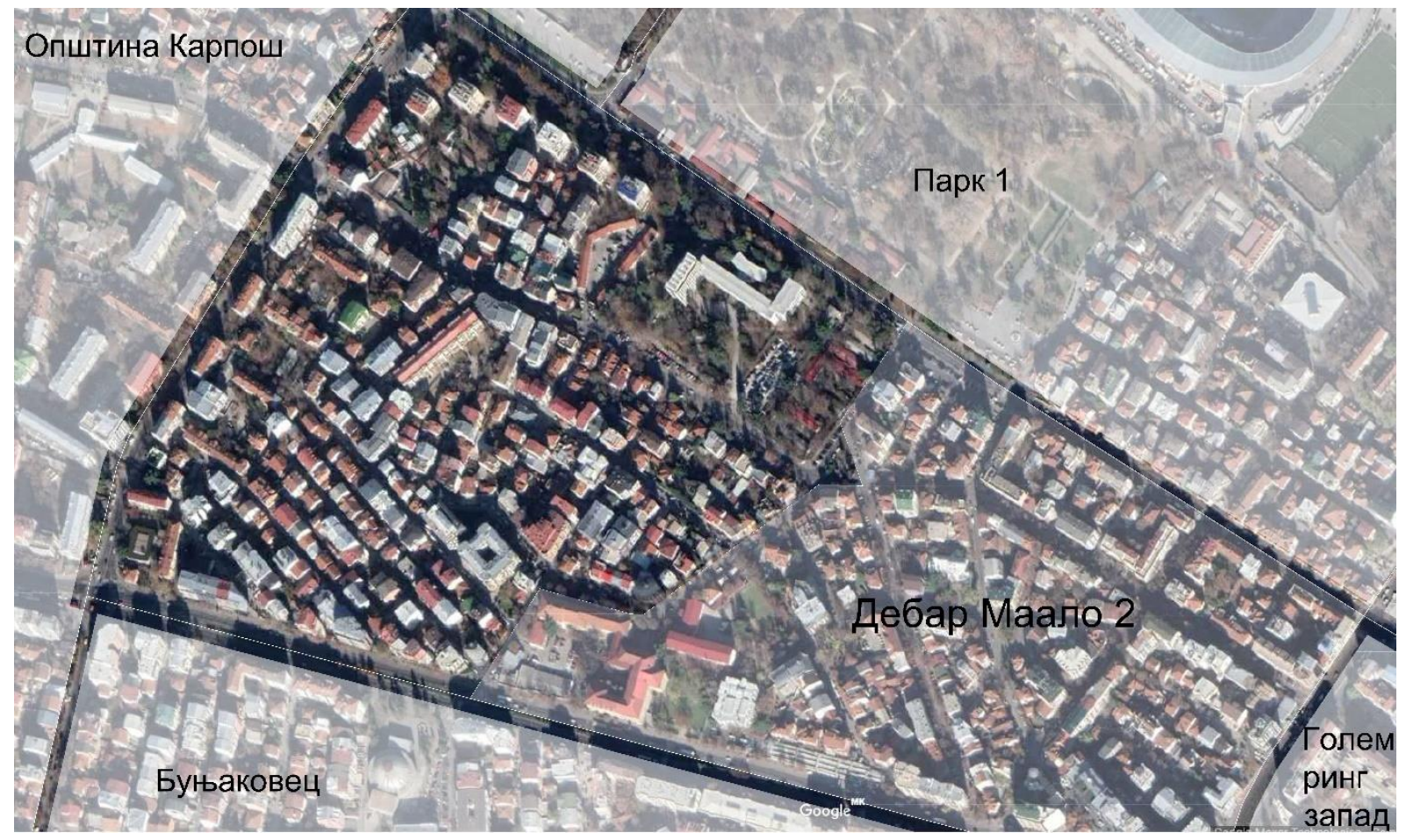

сл.25 - местоположба на Дебар Маало 1

Денес трендот на зголемување на градежната маса несоодветна на морфологијата на оваа градска четврт иницира оформување на граѓански иницијативи за зачувување на маргилизираната фрорма на индивидуално семејно домување и повеќесемејното домување во ниски станбени структури.

Граѓанската иницијатива „Во одбрана на Дебар Маало“ деновиве започна сликовито и детално да ја прикажува состојбата низ Дебар Маало и што ќе се случува доколку се реализираат предложените ДУП-ови за ова урбано градско јадро. Иницијатива дава информации за соодносот на густината на жителите, што би се случило доколку се изградат нови градби, како тие би функционирале во просторот, како сето ќе влијае врз сообраќајната структура, врз квалитетот на живот воопшто.

„Во одбрана на Дебар Маало“ ги поттикнуваат локалните жители да размислуваат и даваат свои ставови, аргументи и предлози за прашањата поврзани со урбанистичкото планирање, а кои се од заеднички интерес. Сметаат дека мора да заживеат урбаните заедници, сите како соседи заедно да се активираат и унапредат сите механизми за партиципативно планирање на ова маало. Сето со цел да се соберат заеднички забелешки и би се создал позитивен притисок врз општинарите од Центар за да направат похрабри чекори во интерес на живеењето на ова урбано јадро, за кое од иницијативата веќе рекоа дека се претвора во супстандардна населба.

Од „Во одбрана на Дебар Маало“ ги прашуваат локалните граѓани дали се согласуваат густината на жителите на Дебар Маало да порасне, па дури и двојно повеќе.

„Тековно, но непроверено заради неажурирани податоци, во Дебар Маало живеат 218 жители на 1 хектар. Новиот план предвидува 449 жители на 1 хектар. Дали се согласувате? Постојната состојба покажува дека доминираат објекти за домување со 
просечна висина Приземје + 1, но планираната не покажува никаде која ќе биде планираната просечна висина. Дали е ова планиран развој на населбата?“, прашуваат од граѓанската иницијатива.

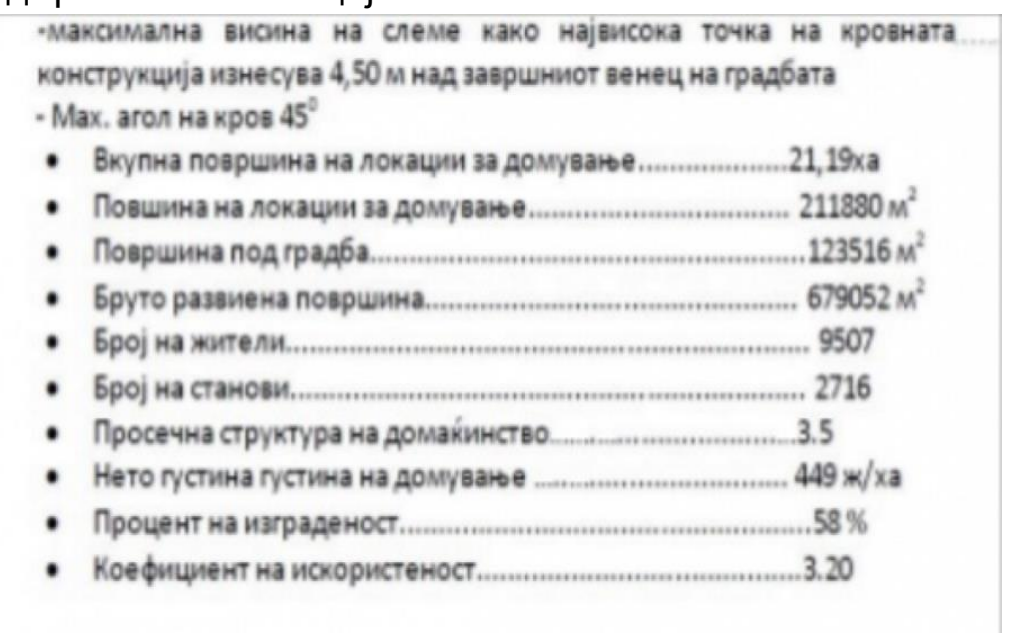

сл.26- Планиран развој на населба Дебар Маало

„Во одбрана на Дебар Маало“ даваат забелешки во однос на усогласеноста на ДУП Дебар Маало со Генералниот урганистички план (ГУП) на Град Скопје 2012-2022. Според сегашниот ГУП, велат од иницијативата, во градска четврт 310 Дебар Маало се предвидува вкупен број на жители - 9.500. Според документационата основа, сегашниот број на жители на истата територија е 10.151.

„Ова значи дека сегашната бројка на жители веќе ја надминува предвидената дозволена бројка според ГУП, и со самото тоа сите надградби/доградби/новоградби кои обезбедуваат место за нови жители се нелегални“, велат од иницијативата. Понатаму, ги прашуваат локалните жители дали се согласуваат во улицата „309“ каде се наоѓa градинката „13 Ноември - Парк“ да никнат станбени објекти во висина над 19 метри.

„Се согласувате ли дел од дворот на градинката да стане дел од улица?“, прашуваат од „Во одбрана на Дебар Маало“.

На државно земјиште, во слепата улица „Чедомир Миндеровиќ“ е предвивидено да никне хотелски комплекс видок над 21 метри. Она што поттикнува недоумници за овој дел е дали оваа улица, која е станбена, е анализирана да може да издржи хотелски комплекс ако постојната комуникална и сообраќајна инфраструктура веќе е недоволна. Исто така, се отвора и прашањето дали да се градат станбени згради над 21 метар до кои нема пристап на возилата. Односно, прашуваат од иницијативата, како се предвидува објект од над 21 метар со паркинг во парцелата, а нема пристапна улица до него?

Од оваа иницијатива пред неколку недели повторија дека, иако е ветено да се почитува законот за изработка на студии во сообраќајот, зеленилото и инфраструктурата, сепак и новиот план се подготвува без ажурирани податоци за реалната состојба без да се изработат овие стручни студии. Се намалуваат обврските за обезбедување паркинг-места, и тие се игнорираат на терен, па целиот крај е задушен со паркирани автомобили, а пешаците и децата се принудени да одат по улица.

„За жал, промените во законот се направени за овие решенија да поминат, а со тоа да се задоволат барањата само и исклучиво на инвеститорите. Доколку целата територија се изгради според можностите на овој ДУП, цело Дебар Маало ќе се претвори во 
нерешен паркинг простор, и сите слободни и отворени и зелени површини, пешачки и велосипедски патеки, барови и ресторани ќе мора да се пренаменат во паркинг места за да ги задоволат потребите на маалото“, рекоа од „Во одбрана на Дебар Маало“.

Од таму потенцираа дека планот овозможува градење според кое зградите ќе бидат премногу блиску една до друга, а со него ќе се направи невозможен пристапот на пожарни и амбулантни коли до зградите. Исто така, рекоа од иницијативата, се предвидува да се руши пазарчето Буњаковец и на негово место да се градат згради и трговски центар два пати повисок од стариот план. Со ова сметаат се овозможува пренамена на сегашното пазарче во парцела со други намени.

„Пазарчето ќе исчезне. Пазарџиите ќе бидат извисени, а нашиот џеб понатаму ќе страда заради трговски центри чиј животен стил е недостижен за сите. Исто така, планот овозможува изградба на објекти како кули, хотели, резиденцијални комплекси на парцелите во државна сопственост, и ако се реализира, се зголемуваат енормно висините, се дозволува приватизирање наместо користење на содржини од јавен интерес, а се губат возрасни, зрели и квалитетни дрвја од контактната зона помеѓу Дебар Маало и Градски парк. Наследните решенија од претходниот ДУП се вон јавниот интерес и бараме да се повлечат“, е цврстиот став на иницијативата.

Здружените граѓани и активисти алармираат дека со изработка и носење на ваков план е спротивно на граѓанскиот интерес, на општиот интерес и демократските принципи. Затоа, укажале пред градоначалникот, пред подготвувачот на планот „БИЛд“ и пред стручната комисија, дека бараат планот да се повлече од процедура и да се врати во нацрт фраза.

Согласно досегашни анализи, нагласија дека ваквите решенија уште повеќе ја деградираат животната средина, но тврдат и исклучително го намалуваат квалитетот на живеење - слаба струја и вода, непристапност за прва помош и пожарна, недостиг на јавни површини, на чист воздух, недостиг на паркинг простор и зголемена загрозеност на пешаците, децата, велосипедистите, недостиг на зелени површини и на игралишта за деца. ${ }^{23}$

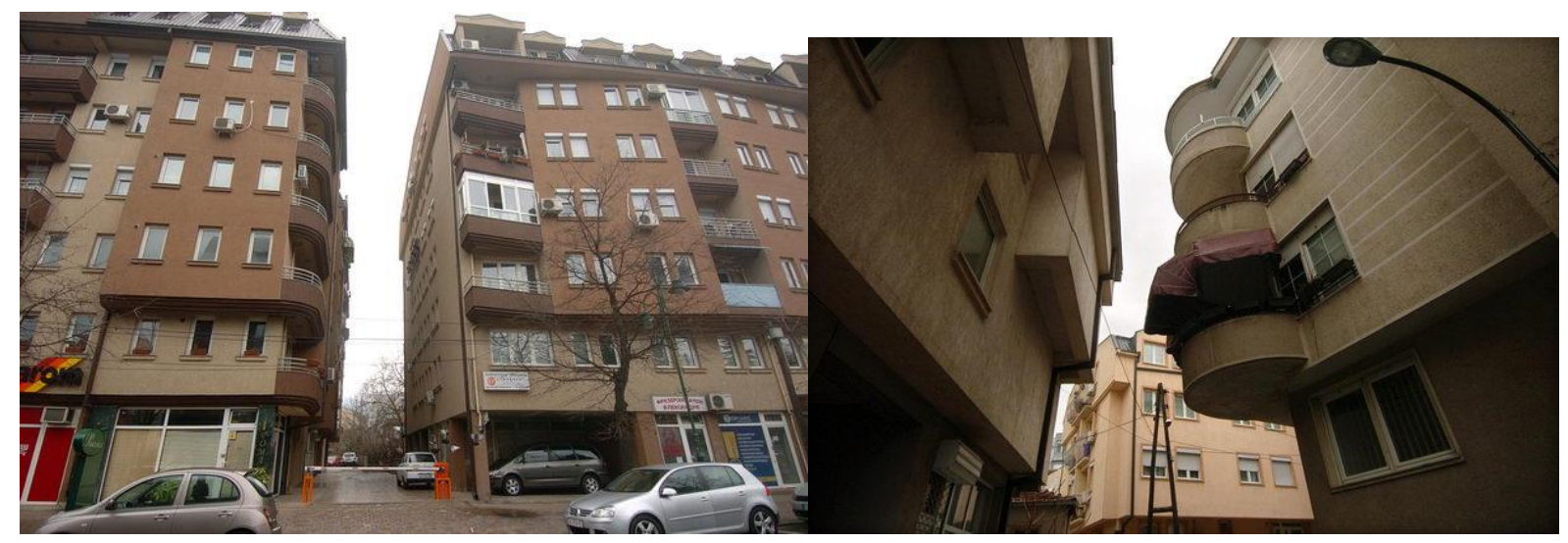

сл.27- денешна слика на Дебар Маало

сл.28- висока густина на градба

\subsection{1. Архитектонско документирање на референтни објекти во Дебар Маало}

Како што е напоменато во предходната точка, првите куќи во Дебар Маало се изградени во 1920 година, на почетокот на XX век. Како референтен извор за основата

\footnotetext{
${ }^{23}$ МКД, „Во одбрана на Дебар Маало“: Се согласувате ли да никнат хотели, згради, паркинзи?, Достапно на: [https://www.mkd.mk/makedonija/skopje/vo-odbrana-na-debar-maalo-se-soglasuvate-li-da-niknat-hotelskikompleks-stanbeni/] , 2019
} 
на оваа анализа се служам со книгата "Градителите во Македонија XVIII-XX BEК” на Георги Константиновски. Во книгата градителите се класифицирани на надворешни и домашни, соодветно вметнати во периодот во кој твореле, нивните дела и местоположбата на нивните дела. За документирање на референтните објекти се земени периодите 1918-1944 и 1944-2000 како периоди во кои во Дебар Маало домувањето во ниска станбена структура било доминантно.

Во поглавјето 1918-1944, се претставени градителите што живееле и твореле во Македонија во периодот меѓу двете светски војни. Непосредно по завршувањето на Првата светска војна, градителството во нашата земја беше насочено кон возобновувањето на урнатините од војната. ${ }^{24}$

Модерната архитектура во Македонија во периодот од 1944-2000 година зафаќа две етапи во својот развој. Првата етапа се одвива во периодот од 1944- 1962 кога најголемо влијание беше посветено на изградбата на земјата по завршетокот на Втората светска војна. Во овој период не со помал интензитет се градат станбени објекти и станбени комплекси чија што изградба подлежи, речиси на истите критериуми како и изгрдбата на индустриските објекти.

Втората градителска етапа започнува по 1963 кога главниот град на Републиката беше разурнат од катастрофралниот земјотрес. ${ }^{25}$

Надворешни градители, 1918-1944

Милан М. Николиќ:

1932 - Индивидуална семејна куќа (П+1) на Лефтерија Поповиќ на аголот на улиците “Генерал Ковачевиќ” (“Антоние Грубишиќ”) и “Облиќев Венец” (“Ленинова”/ “Аминта Трети");

Домашни градители, 1918-1944

Иван Артемушкин

$1927^{*}$ - Повеќесемејна станбена зграда на д-р. Рубен (Сут+П+2+По) на аголот на бул. “Илинден” и ул. "Наум Наумовски- Борче";

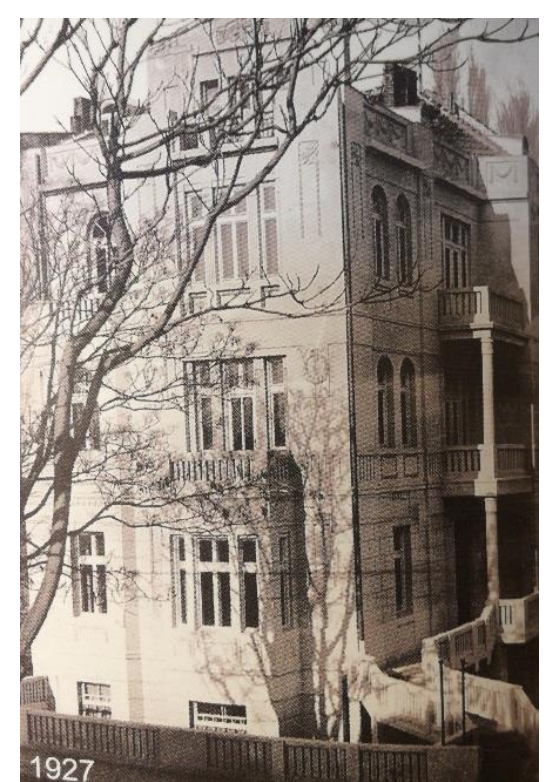

сл.29 - станбена зграда на д-р. Рубен, градител Иван Артемушкин

\footnotetext{
${ }^{24}$ Константиновски, Георги, “Градителите во Македонија, XVIII- XX ВЕК”, 2001, стр. 57

${ }^{25}$ Константиновски, Георги, “Градителите во Македонија, XVIII- XX ВEК”, 2001, стр. 122
} 
1930 - Индивидуална семејна куќа (Сут+П+2) на Соломон Манахем на улица бул. “Илинден”;

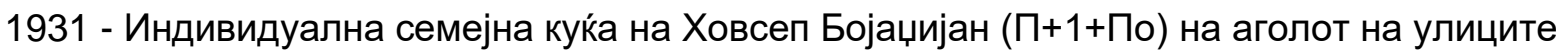
"Орце Николов" и "Раде Кончар" ;

Николај Бурхановски

1938 - Индивидуална семејна куќа (П) на Јово Видовиќ на аголот на ул."Наум Наумовски- Борче"

Вајчеслав Бујко 1938*- Индивидуална семејна куќа (Сут+П) на Надежда Јеремиќ на ул. “Михајло Церовиќ” (“Алберт Ајнштајн”);

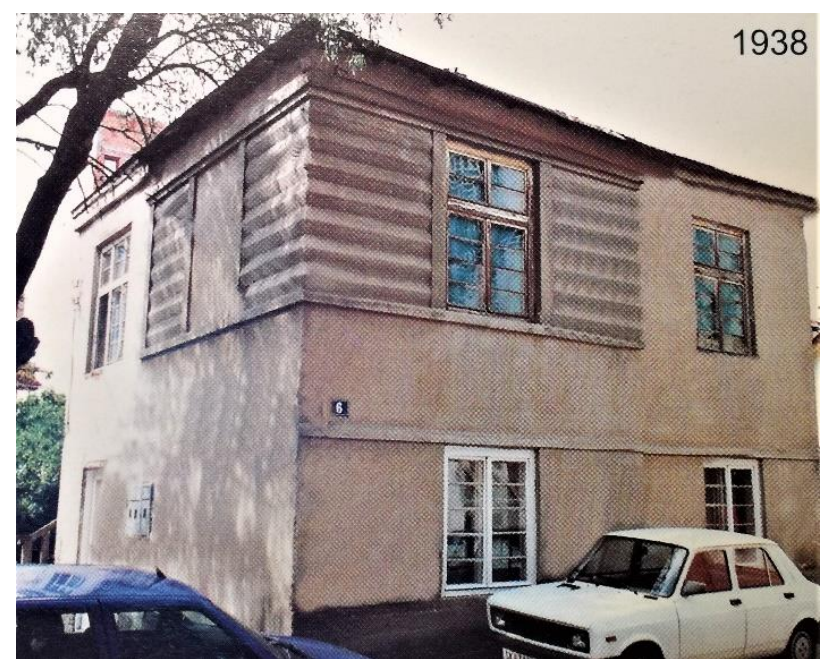

сл.30- индивидуална семејна куќа, градител Вајчеслав Бујко

\section{Рудолф Вошта}

1925 - Куќата на Милош Благојевиќ (Сут+П) на ул. “Ѓуро Ѓаковиќ”;

-Куќата на Добривое Дициќ (Сут+П) на аголот на улиците “Ѓуро Гаковиќ” и “Антоние Грубишиќ"

1930 - Куќата на Велко Трајковиќ (П) на ул. “Дебарца”

Јан Дубови

1936* - Индивидуална семејна куќa (Сут+П+1) на Зденка Буста на ул. "Орце Николов"

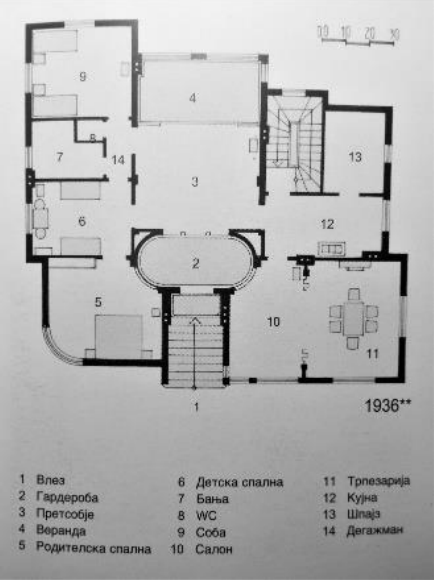

сл. 31- основа на индивидуална семејна куќа, градител Јан Дубови 
1938 - Станбен објект (П+1) на Стархиња Јовановиќ на ул. “Ѓуро Ѓаковиќ” бр.74

Борис Дутов

1925 - Индивидуална семејна куќа $(П+1)$ на Трајко Анчевиќ на ул."Ленинова"

- Индивидуална семејна куќа (Сут+П) на Мирослав Живиќ на ул."Ленинова"

$1931^{*}$ - Индивидуална семејна куќа $(П+2)$ на Богое Армагањан на аголот на ул. "Наум Наумовски- Борче" и "27-ми Март";

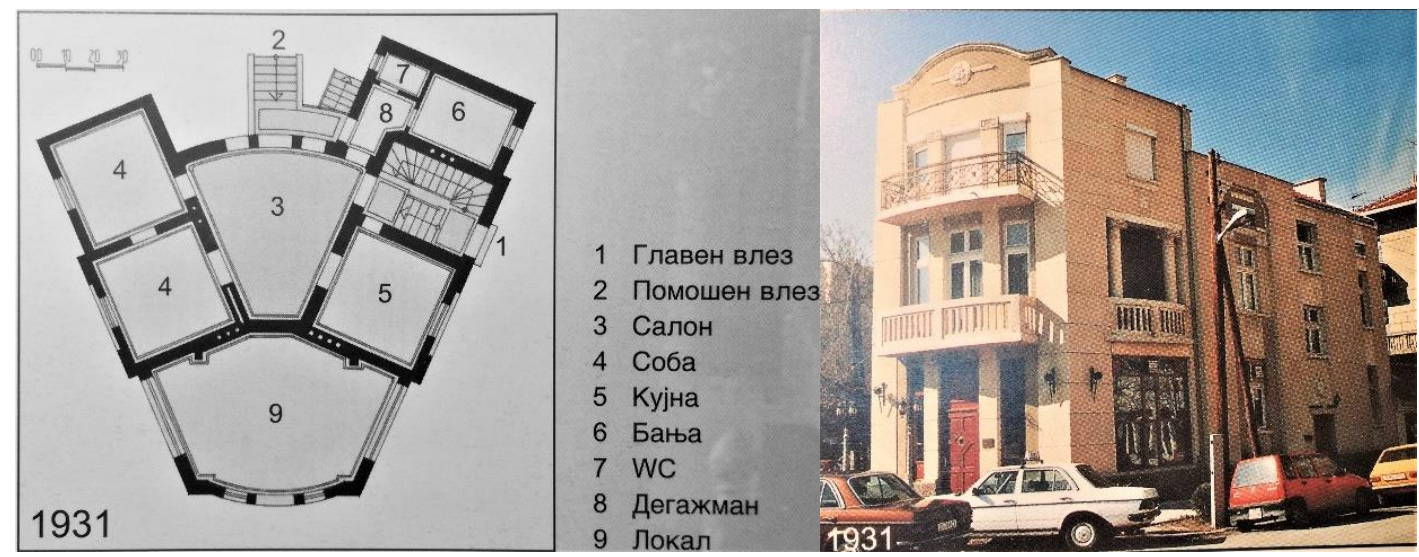

сл.32- основа на инд. сем. Куќа, градител Борис Дутов сл.33- градител Борис Дутов

\section{Кирил Жерновски}

1927 - Индивидуална семејна куќа (Сут+П) на Илија Јовановиќ на ул. "Орце Николов" ; 1932 - Станбен објект (Сут+П+3) на Јаков Талви на ул.”Наум Наумовски- Борче”; $1938^{*}$ - Индивидуална семејна куќа (Сут+П) на Бошко Буњак на ул."Ѓуро Гаковиќ”

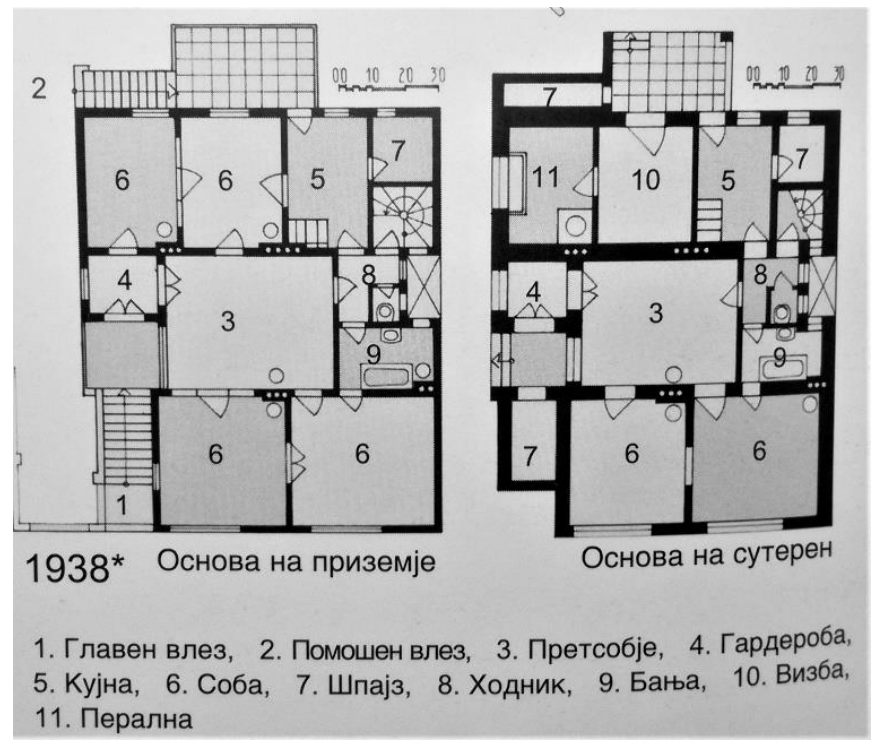

сл.34- инд. сем. Куќа, градител Кирил Жерновски

1940 - Индивидуална семејна куќа (Сут+П) на Јован Ѓорѓевиќ на ул. “Ѓуро Ѓаковиќ” 1940* - Станбен објект (П+2) на аголот на ул. “Ленинова" и “Димитрие Туцовиќ" 


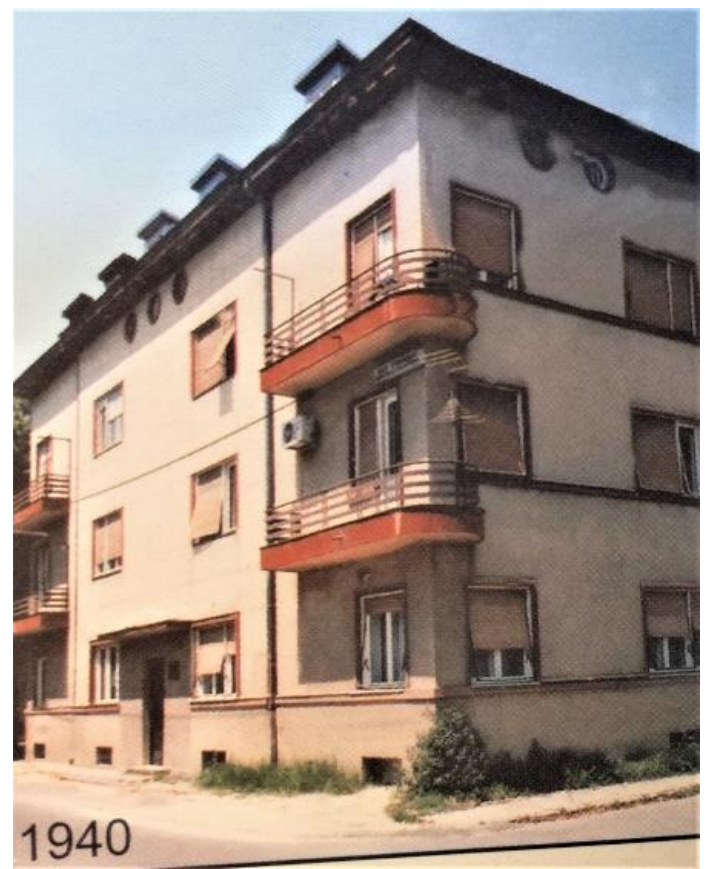

сл.35- станбен објект, градител Кирил Жерновски

\section{Драгутин Илиќ}

1936 - Индивидуална семејна куќа (П+1) на Ружа Видовиќ на ул."Наум Наумовски-

Борче"

$1937^{*}$ - Станбен објект (Сут+П+1) на Драгољуб Аврамовиќ на ул."Ѓуро Ѓаковиќ” бр.67а

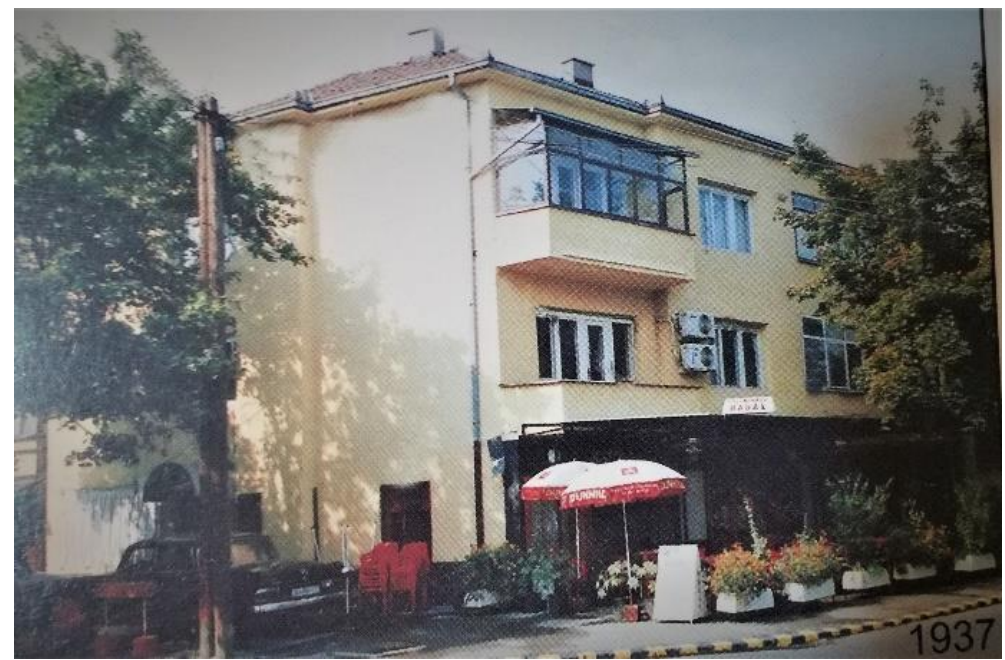

сл.36- станбен објект, градител Драгутин Илиќ

Петар Јанковиќ

1926* - Индивидуална семејна куќа (Сут+П) на Милорад Бранковиќ на ул. "Ленинова" 1926 - Индивидуална семејна куќа на Јован Котевиќ на ул. "Ѓуро Ѓаковиќ”

\section{И. Кавтиќ}

1924* - Индивидуална семејна куќа $(П+1)$ на Иван Глигоревиќ на аголот на ул."Илинденска" и ул. "Ленинова" 


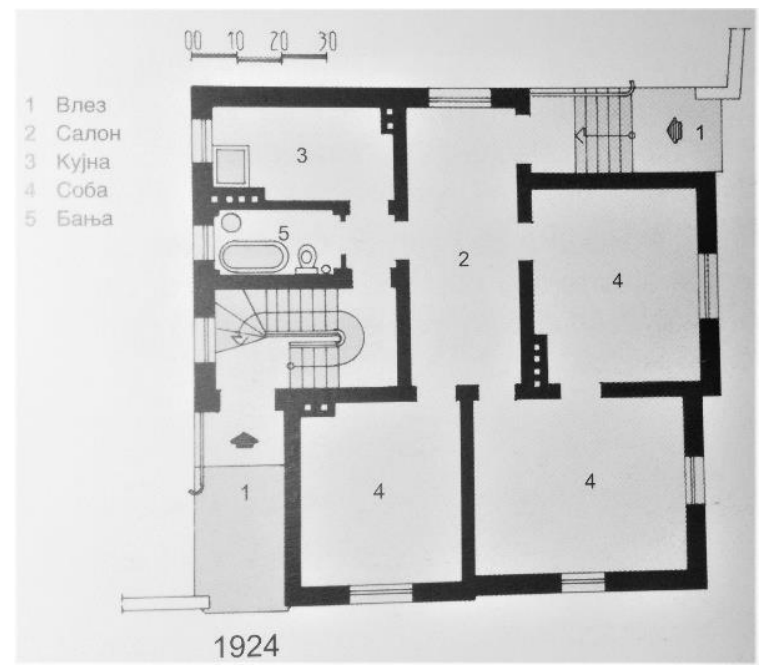

сл.37- основа на инд. сем. куќа, градител И. Кавтиќ

Милан Карло Котек

1925* - Индивидуална семејна куќа (Сут+П) на Властимир Милкиќ на ул. "Илинденска”;

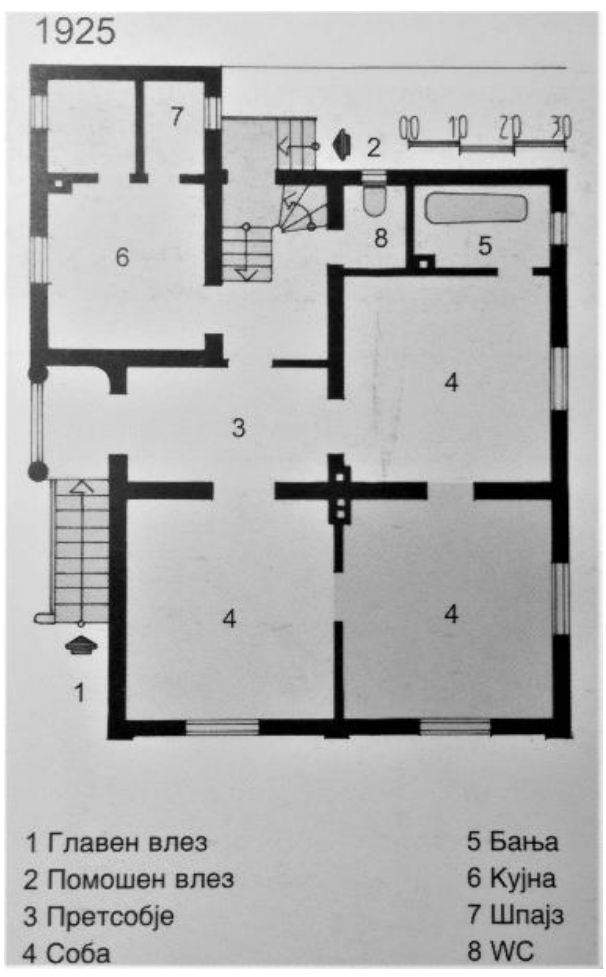

сл.38- основа на инд. сем. куќа, градител Милан Карло Котек

\section{Фердо Краус}

1933 - Индивидуална семејна куќа (П) на Лука Ѓорѓевиќ на аголот на ул. "Раде Кончар" и "Антоние Грубишиќ"

-Индивидуална семејна куќа на Спасенија Кузнецова на ул. “Дебарца”

$1935^{\star}$ - Индивидуална семејна куќа (П+2) на Тома Ничота на ул. “Орце Николов”, бр.88 


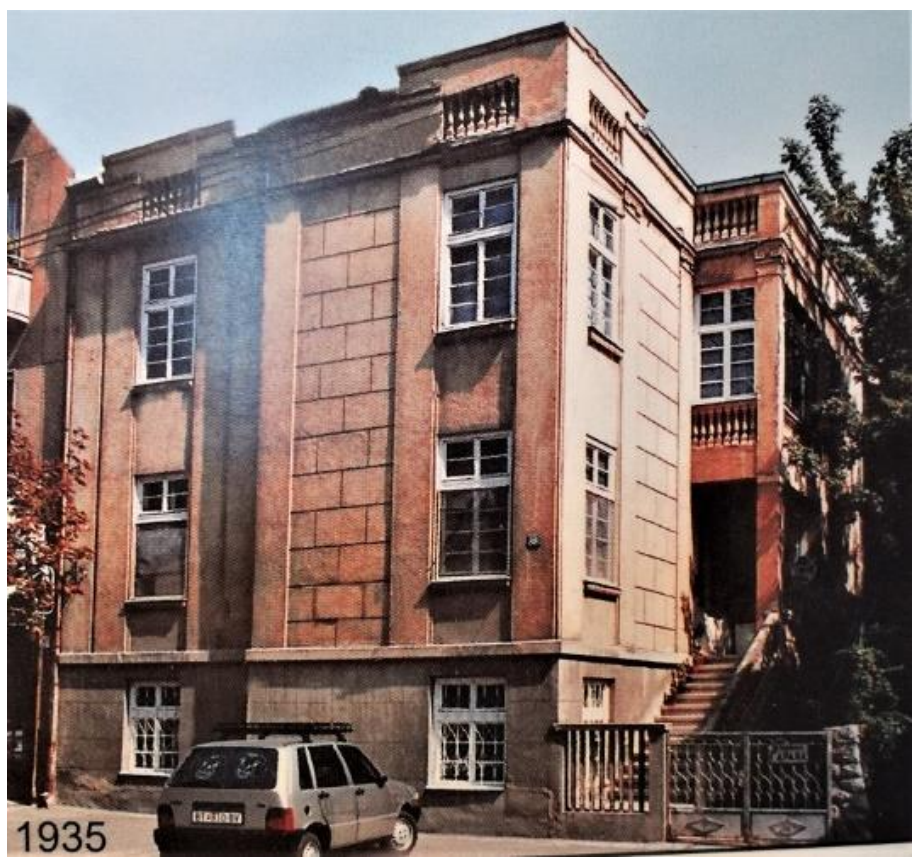

сл.39- инд. сем. куќа, градител Фердо Краус

\section{Михаил Матвеев}

1937 - Индивидуална семејна куќа (П) на Стојан Ацевиќ на ул. “Орце Николов” бр.160 $1939 *$ - Индивидуална семејна куќа $($ Сут+П+1) на Ристо Јорданов Лазов, на аголот на ул. “Антонио Грубишиќ” и “Дебарца” бр.43

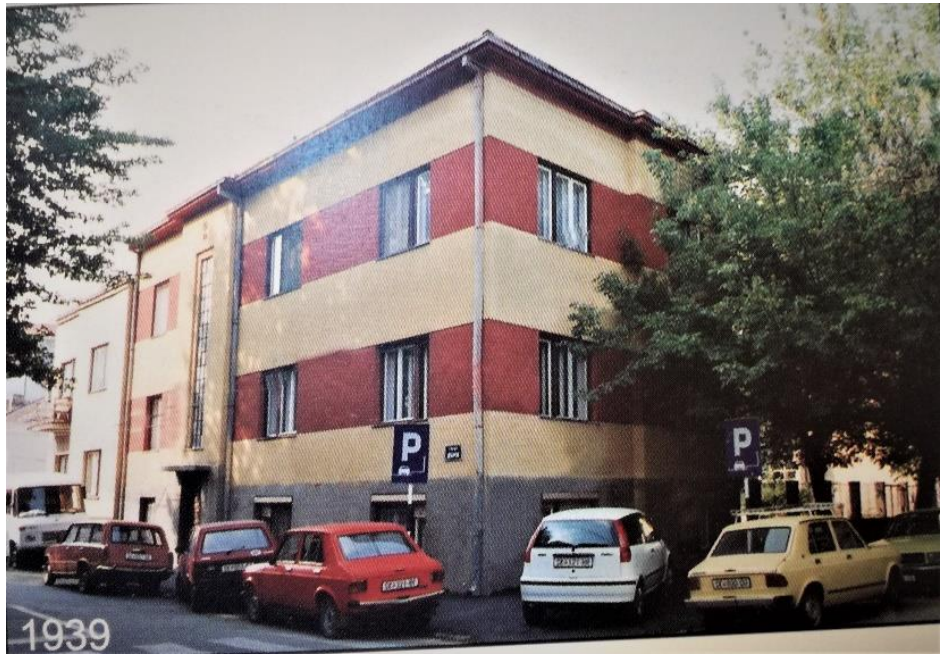

сл.40- инд. сем. Куќа, градител Михаил Матвеев

Божидар Нешовиќ

1931 - Индивидуална семејна куќа (Сут+П) на Милан Анастасиевиќ на ул. Наум Наумовски- Борче;

1933 - Индивидуална семејна куќа (Сут+П) на Стеван Газикаловиќ на ул. “Ѓуро Ѓаковиќ”

Исајло Јованов Николовски

$1934^{*}$ - Индивидуалната семејна куќа $(П+1)$ на Илија Смилјановски на ул." Дане

Крапчев", бр.19 


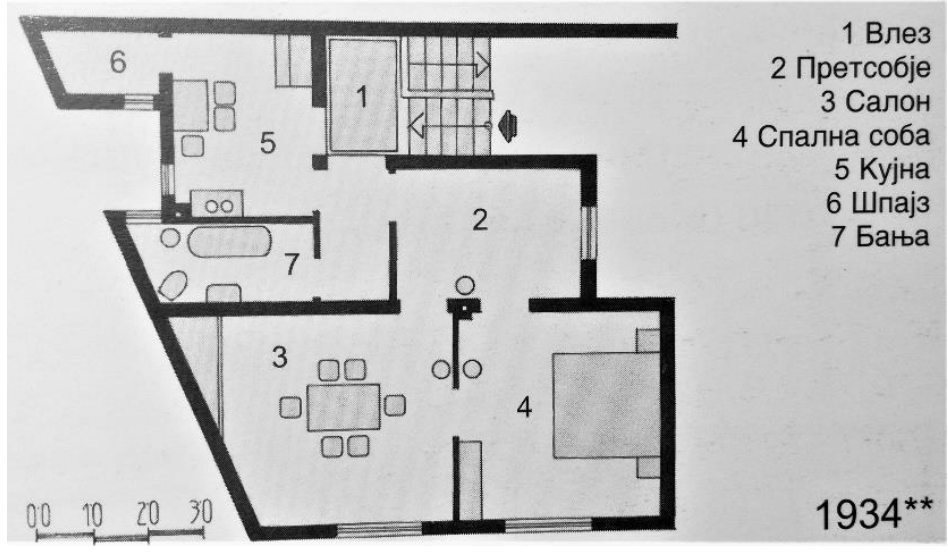

сл.41- основа на инд. сем. Куќа, градител Исајло Јованов Николовски

1936* - Индивидуална семејна куќа (П) на Јосип Пулизевиќ на ул. “Орце Николов” бр.4 -Индивидуална семејна куќa (П+1) на Јордан Гагуловиќ на ул. “Антоние Грубишиќ” бр.2

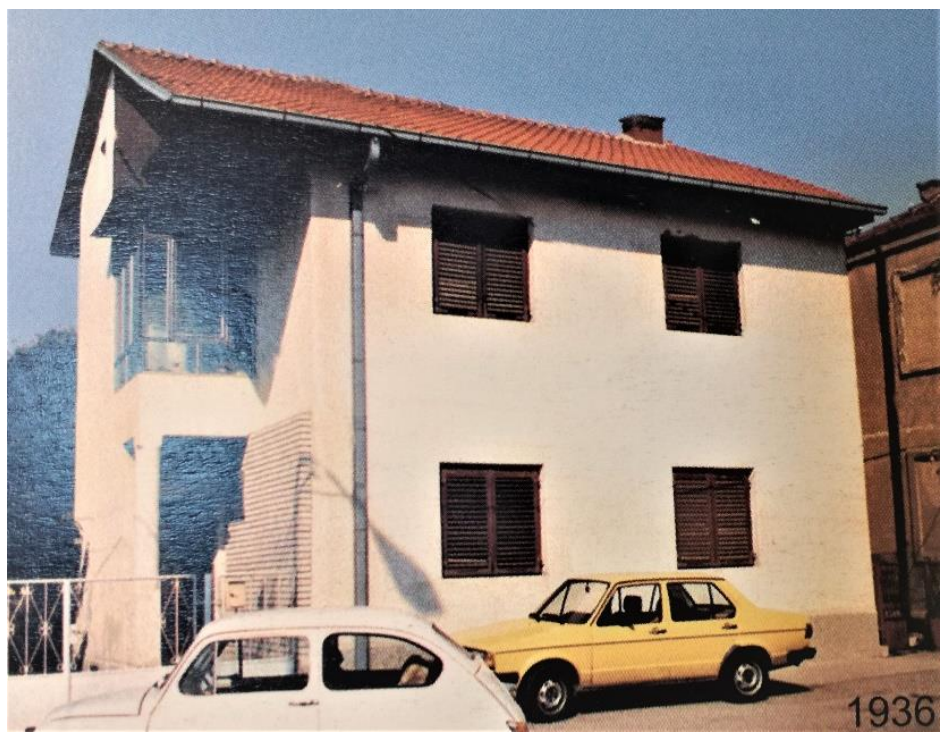

сл.42- инд. сем. Куќа, градител Исајло Јованов Николовски

Бранислав Протиќ

1928 - Индивидуална семејна куќа (П+2) на Владимир Исаков на ул. “Црвена Вода” бр.17

1936 - Станбен објект (Сут+П+2) на Димитар Кузмановиќ на аголот на улиците "Орце Николов" и "Раде Кончар"

Хранислав Спасиќ

1925 - Индивидуална семејна куќа (П) на Васил Лепчевиќ на аголот на ул. "Ѓуро Гаковиќ" и "Св. Климент Охридски"

1925* - Индивидуална семејна куќа $(П+1)$ на Хранислав Спасиќ на ул. “Пиринска”

М.Тасиќ

1924* - Индивидуална семејна куќа (П) на Пане Мухетовиќ на ул. “Кариќева” на ул. “Дебарца" 


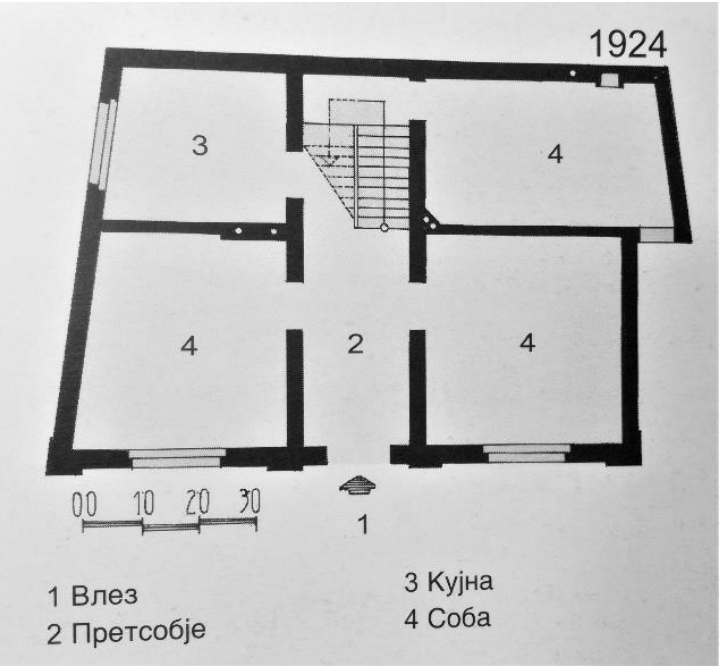

сл.43- основа на инд. сем. Куќа, градител М. Тасиќ

\section{Ѓорѓе Ристиќ}

1939 - Станбен објект (П+2) на Катерина Папатеодоси на ул."Ленинова" бр.17

-Индивидуална семејна куќа (П) на Ристо Миленковиќ на ул. “Антоние Грубишиќ” бр.57

Глигорие Ташковиќ

1940* - Станбениот објект (П+3+По) на Гигорие Ташковиќ на аголот од улиците “Орце Николов" и “Ленинова"

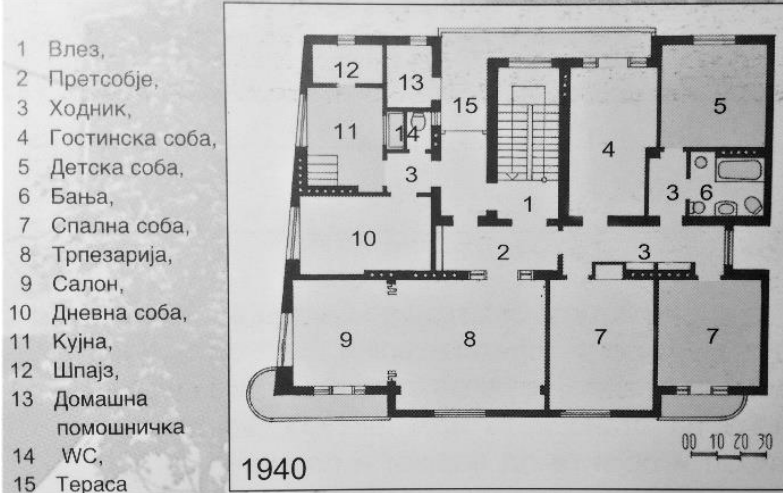

сл.44- основа, Глигорие Ташковиќ

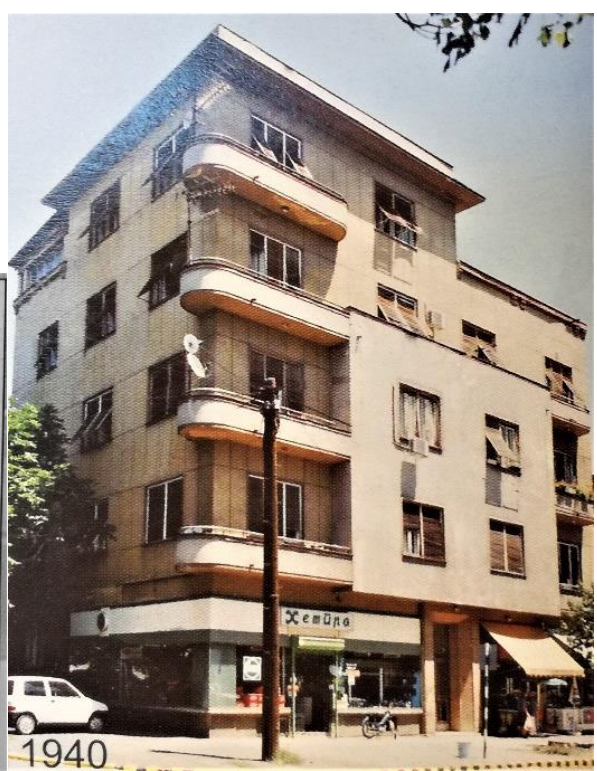

сл.45- станбен објект, Глигорие Ташковиќ

\section{Константин Хоменко}

1924* - Индивидуална семејна куќа (Сут+П+1) на Стефан Коцес на ул."Илинденска"

Кирило Хаџи Наковиќ

1925 - Индивидулната семејна куќa (Сут+П) на Никола Лазаревиќ на аголот на улиците "Илинденска" и "234"

1926 - Индивидуална семејна куќа (П) на Русе Блажевиќ на ул. “Илинденска”

\section{Глигорие Томиќ}

1926 - Индивидуалната семејна куќа (П) на Тасе Антиќ на улица "Антоние Грубишиќ" 1927 - Индивидуална семејна куќа $(П+1)$ на Елена Атансиевиќ на ул. "Ленинова" 
Пајо Шулентиќ

1938* - Индивидуална семејна куќа $(П+1)$ на Јован Николиќ на аголот од улиците "29-ти Ноември" и “Дебарца"

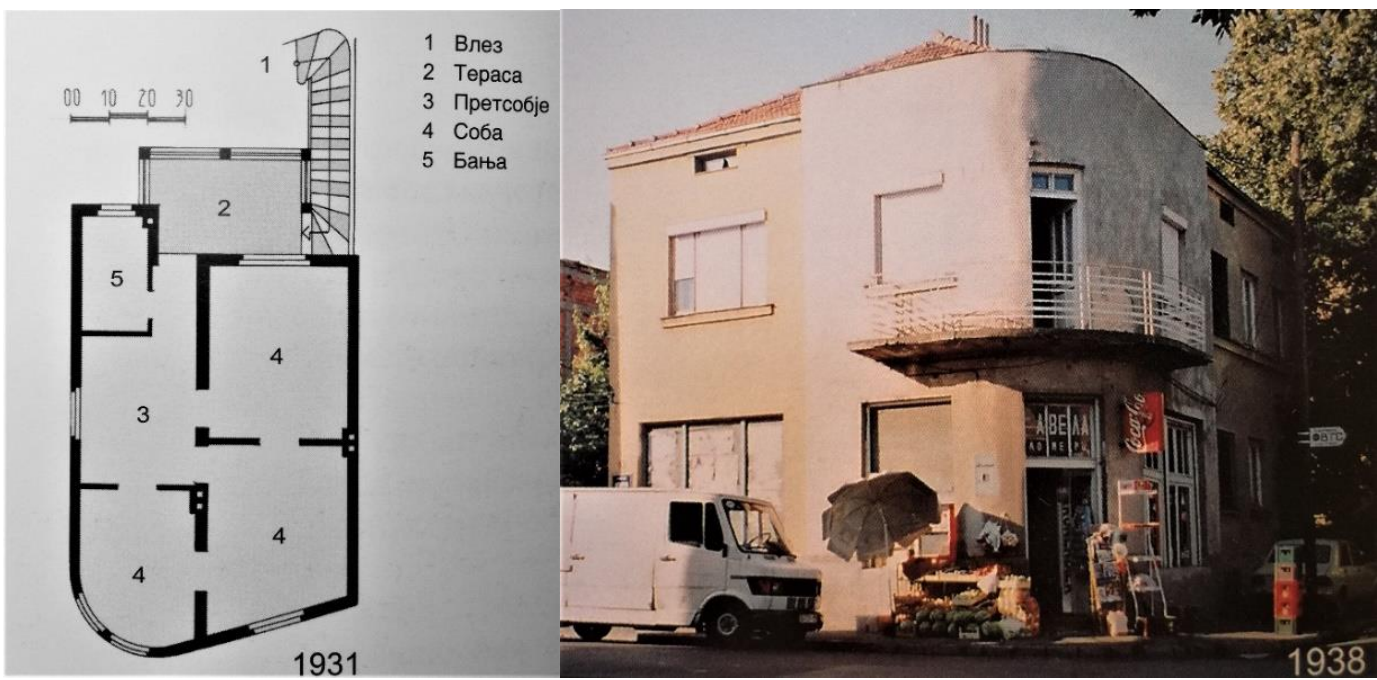

сл.46- основа, Пајо Шулентиќ

сл.47- инд. сем. Куќа, градител Пајо Шулентиќ

-Индивидуална семејна куќа (Сут+П) на Пајо Шулентиќ на аголот на улиците "29-ти Ноември" и "Дебарца"

Домашни градители, 1944 - 2000

Славко Брезовски

1954 -Станбен блок на аголот на бул. “Св. Климент Охридски” и ул. “Орце Николов”

Петко Јосифовски

1952* - Станбен блок на ул. “29-ти Ноември” (П+4)

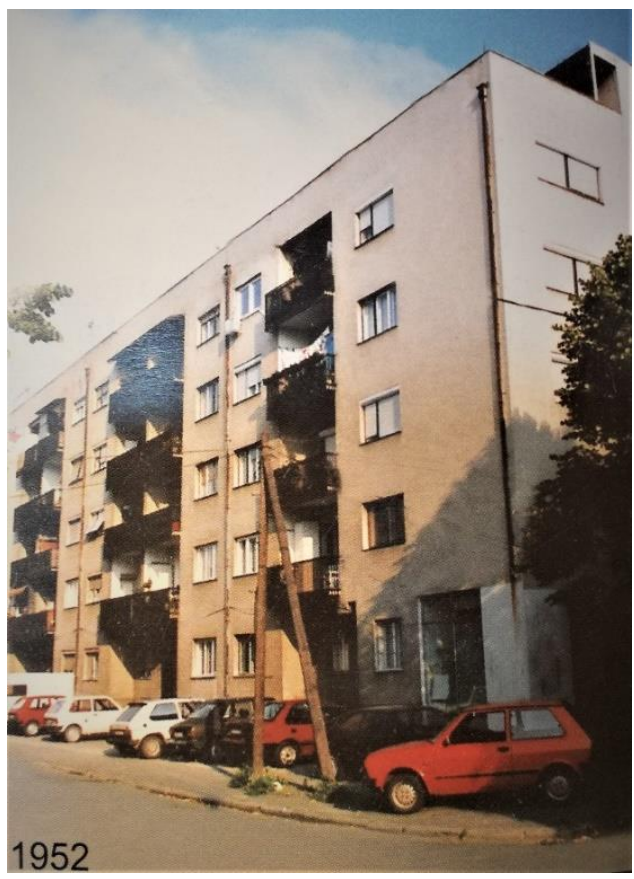

сл.48- станбен блок, градител Петко Јосифовски

Лудјек Кубеш

1952* - Станбените објекти на ул. “Орце Николов” (П+1 и П+3) 


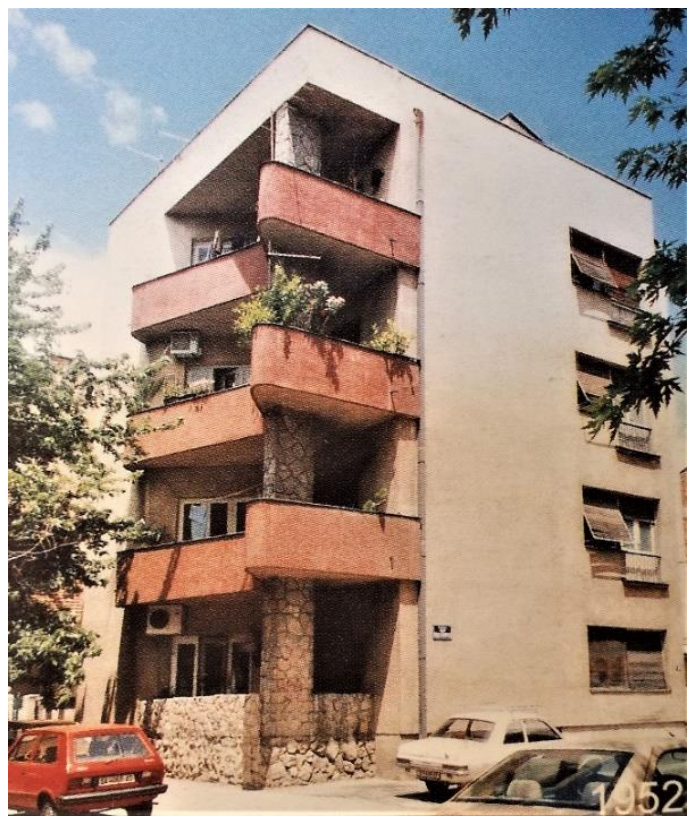

сл.49- станбен објект, градител Лудјек Кубеш

\section{Василка Ладинска}

$1958 *$ - Петте станбени кули (П+6) на бул. "Илинден”

1986* - Станбен објект (П+2) на бул. “Илинден” бр.70

$1987^{*}$ - Станбен објект (П+3) на бул. “Илинден” бр. 46/48

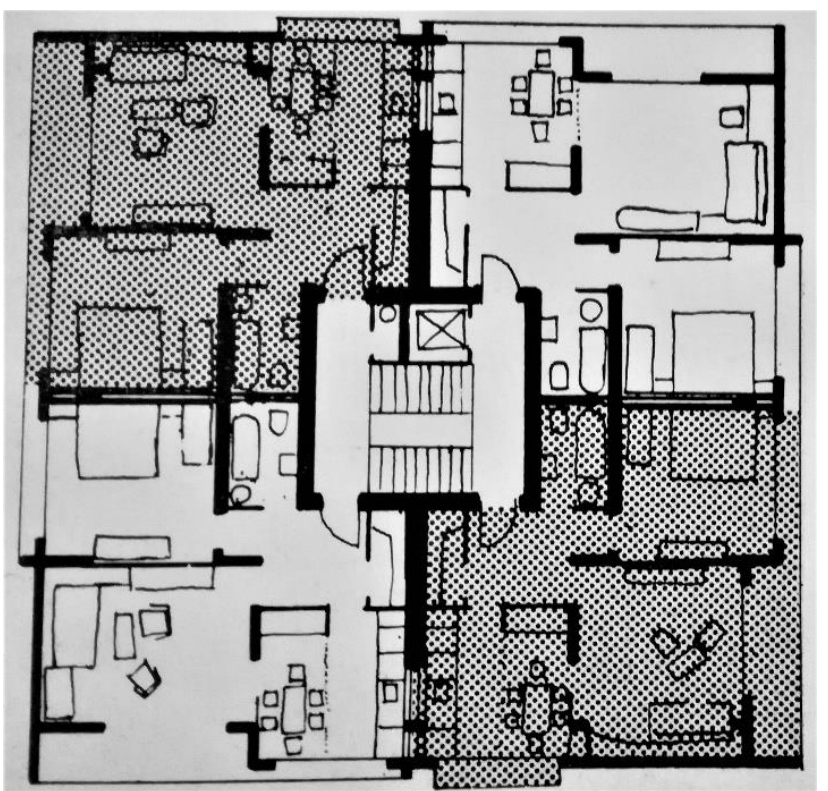

сл.50- карактеристичен кат на станбена кула, градител Васка Ладинска

Душан Пецовски

1959 - Станбен објект (П+3) на ул. “Орце Николов"

Глигорие Савовиќ

1952/53 - Станбен Блок (П+3) на аголот на бул. “Илинден” и ул. “Ленинова”

Љубомир Томиќ

1960* - Станбен блок (П+3) на ул. “Алберт Ајнштајн”, бр.1 


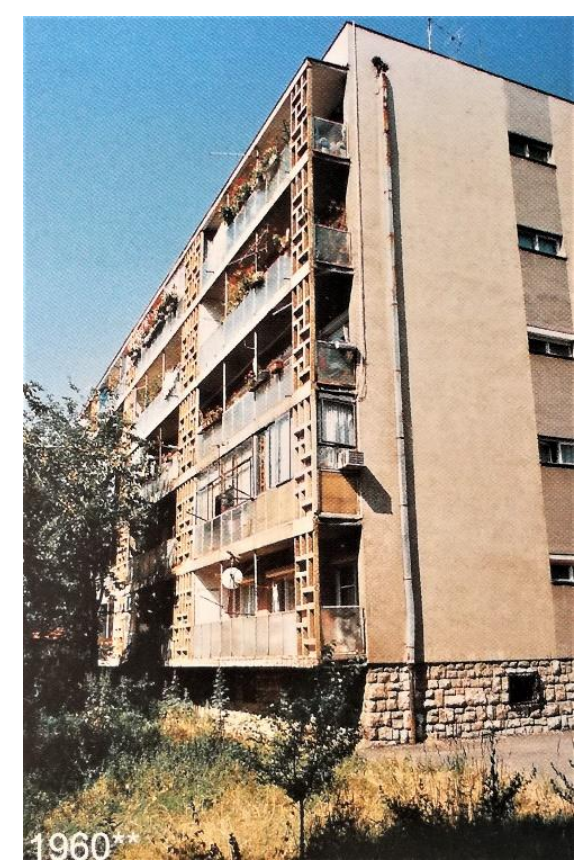

сл.51- станбен блок, градител Љубомир Томиќ

\section{Драган Томовски}

$1947^{\star}$ - Станбените блокови (П+1) во Дебар Маало

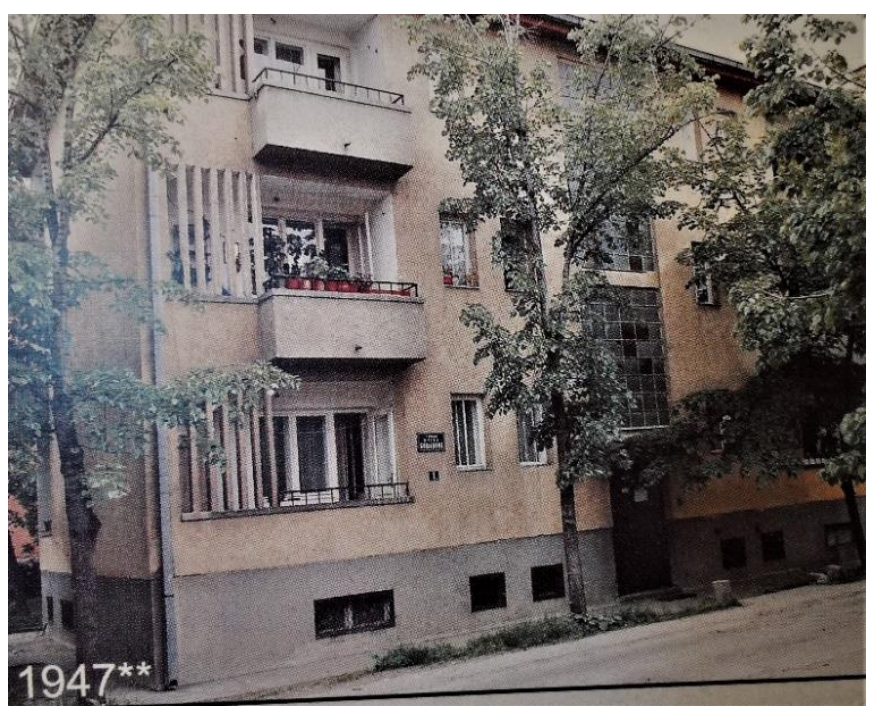

сл.52- станбен блок, градител Драган Томовски

\section{Сотир Томоски}

1953* - Станбен објект на бул. “Илинден” бр.61

1954 - Индивидуална семејна куќа на ул. “Орце Николов”, 113 во Скопје 


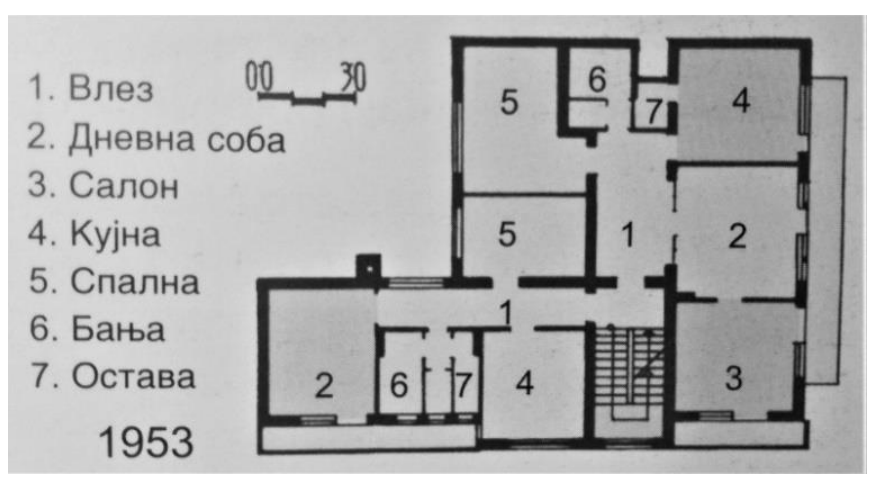

сл.53- основа на инд. сем. куќа, градител Сотир Томоски

Вера Ушинска- Жежова

1958 - Станбени кули на бул. "Илинден"

Имре Фаркаш

1955* - Станбен блок на универзитетските наставници (П+3) на улиците "Орце Николов”, “Ленинова" и "Илинденска” во Скопје (со архитектот Ристо Шеќерински)

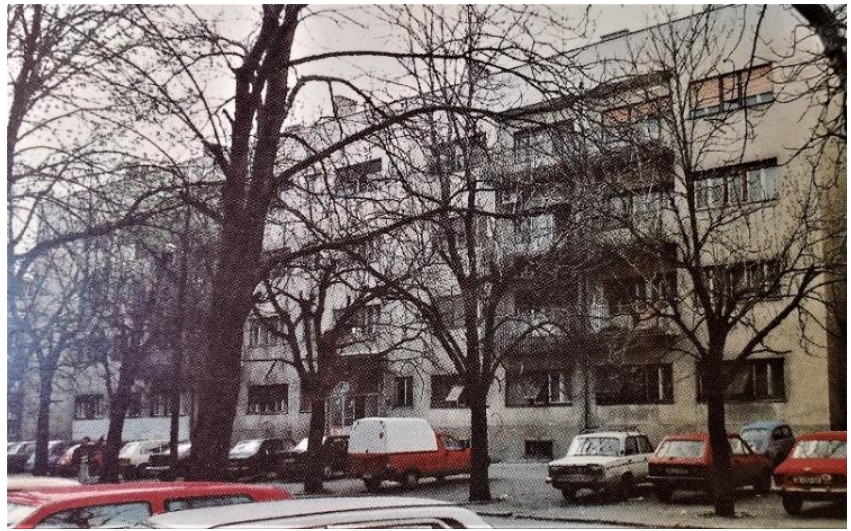

сл.54- станбен блок, градител Имре Фаркаш

Архитектонското документирање на референтните објекти во Дебар Маало се одвива на неколку карактеристични улици: бул. "Илинден" (во непосредна близина на предметната локација), ул. “Орце Николов” (во непосредна близина на предметната локација),, ул. “Аминта Трети”, ул. "Алберт Ајнштајн” (во непосредна близина на предметната локација),, ул. “Дебарца”, ул. “Дане Крапчев”, ул. “29ти Ноември”, ул. “Антоние Грубишиќ”, ул. “Ѓуро Ѓаковиќ”, ул. "Наум Наумовски- Борче”, ул. “Пиринска”, кои се мапирани во приложениот графички приказ: 


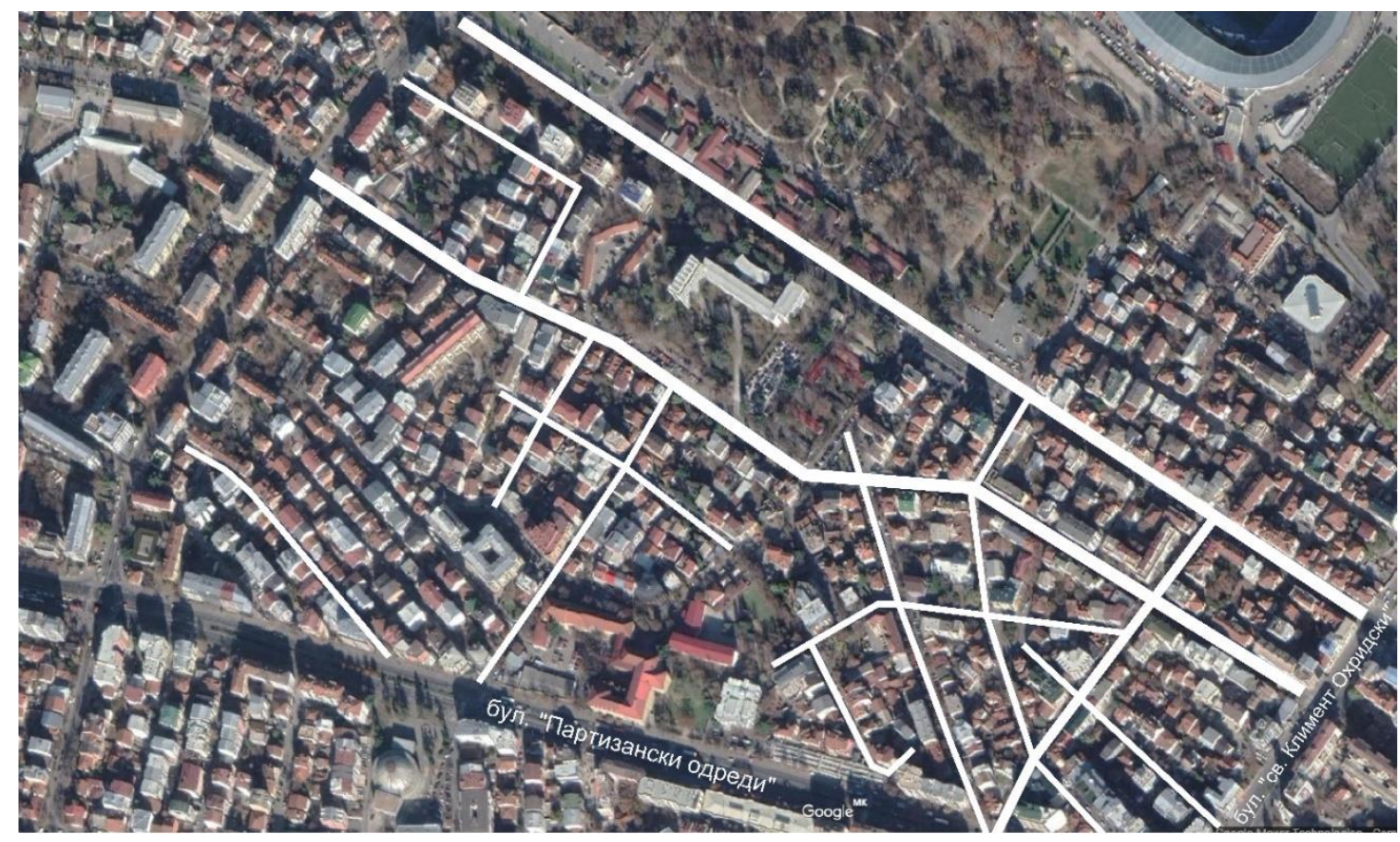

сл.55- мапирање на улици на документирани објекти

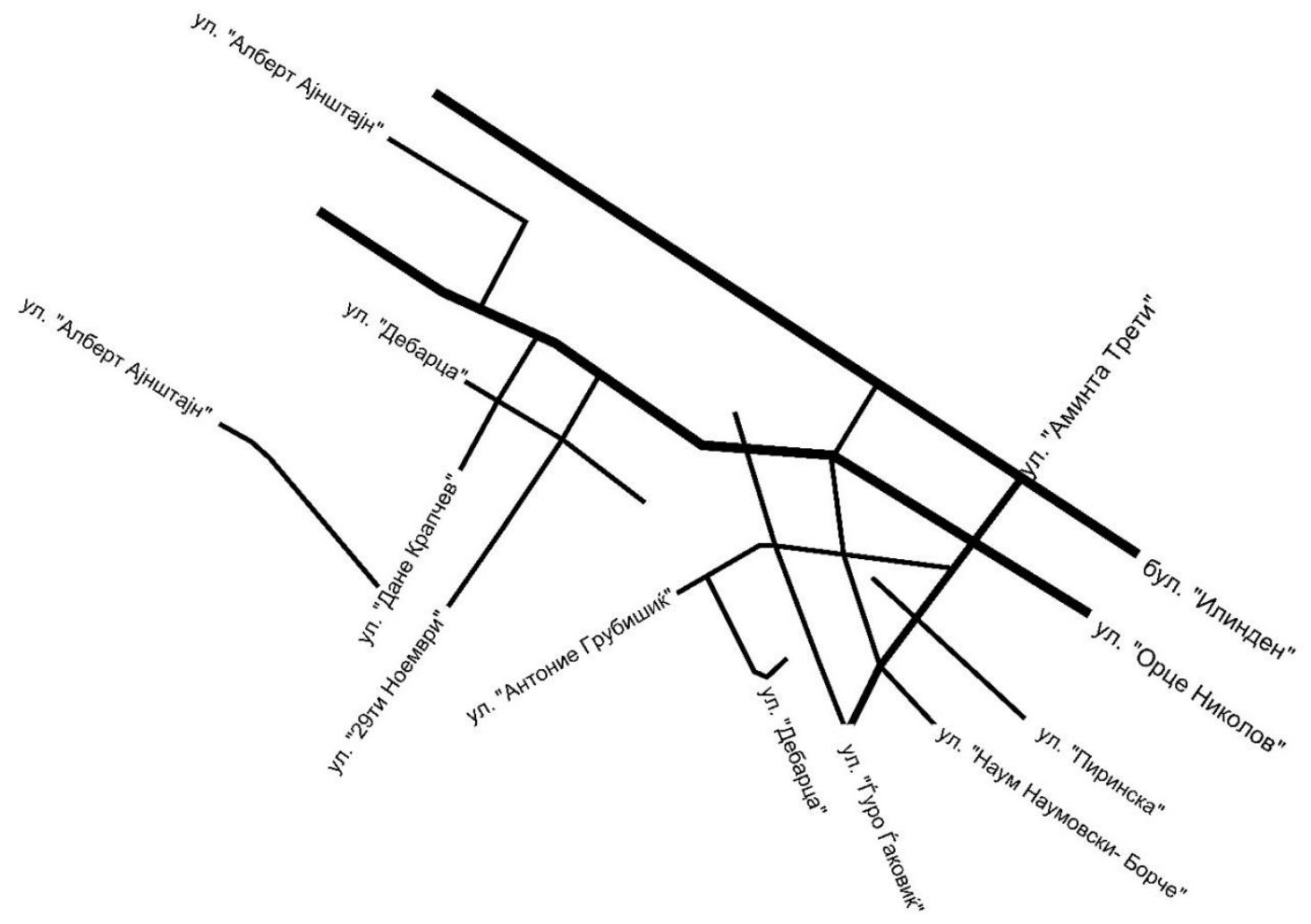

сл.56- мапа на улици на документирани објекти

Во табелата се сублимирани податоци за градителската дејност во Дебар Маало, документирани во кингата "Градителите во Македонија XVIII-XX ВEК" на Георги Константиновски, поделена во два периоди (1918-1944 и 1944-2000) и типологијата на објектите кои се изградени. Типологијата на индивидуална семејна куќа е доминантна во периодот 1918-1944, каде се изградени 42 објекти од 63 документирани. Станбените објекти или повеќесемејни згради еднакво се застапени во двата периоди, додека станбените блокови и станбените кули се градат во периодот од 1944-2000 година каде 
се зголемува капацитетот на градот Скопје и соодветно се појавува потреба од зголемување на градежниот фонд.

\begin{tabular}{|c|c|c|}
\hline & 1918-1944 & $1944-2000$ \\
\hline $\begin{array}{c}\text { Индивидуална семејна куќa } \\
(П / \text { Сут+П/ П+1) }\end{array}$ & 42 & 2 \\
\hline $\begin{array}{c}\text { Станбен објект/ } \\
\text { повеќесемејна зграда } \\
(П+2)\end{array}$ & 6 & 5 \\
\hline $\begin{array}{c}\text { Станбен блок } \\
(П+1 / \Pi+3)\end{array}$ & 1 & 6 \\
\hline $\begin{array}{c}\text { Станбена кула } \\
(П+6)\end{array}$ & / & 2 \\
\hline
\end{tabular}

Табела 1- градежен фонд 1918-1944/ 1944-2000

\section{2. Архитектонско образложение на проектот}

\subsection{1.Анализа на урбан опфат}

Урбаниот опфат кој е предмет на анализа е лоциран во западниот дел на градската четврт Дебар Маало во Скопје- Дебар Маало 1. Поточно завзема 8 катастарски парцели (5178/1, 5178/9, 5178/12, 5175/3, 5177, 5175/2, 5179/2, 5178/8) со намени "А1домување во станбени куќи", "општински органи" и "згради во останато стопанство”, на кои има постојни дотрајани приземни бараки кои служат како деловни простории на "Акционерско друштво за изградба и стопанисување со станбен простор и со деловен простор од значење на Републиката- Скопје” чиј опфат се граничи со ул.“Орце Николов" југозапад, со ул. "Алберт Ајнштајн” на североисток и со ниски и средно високи станбени структури на југоисточната и северозападната страна.

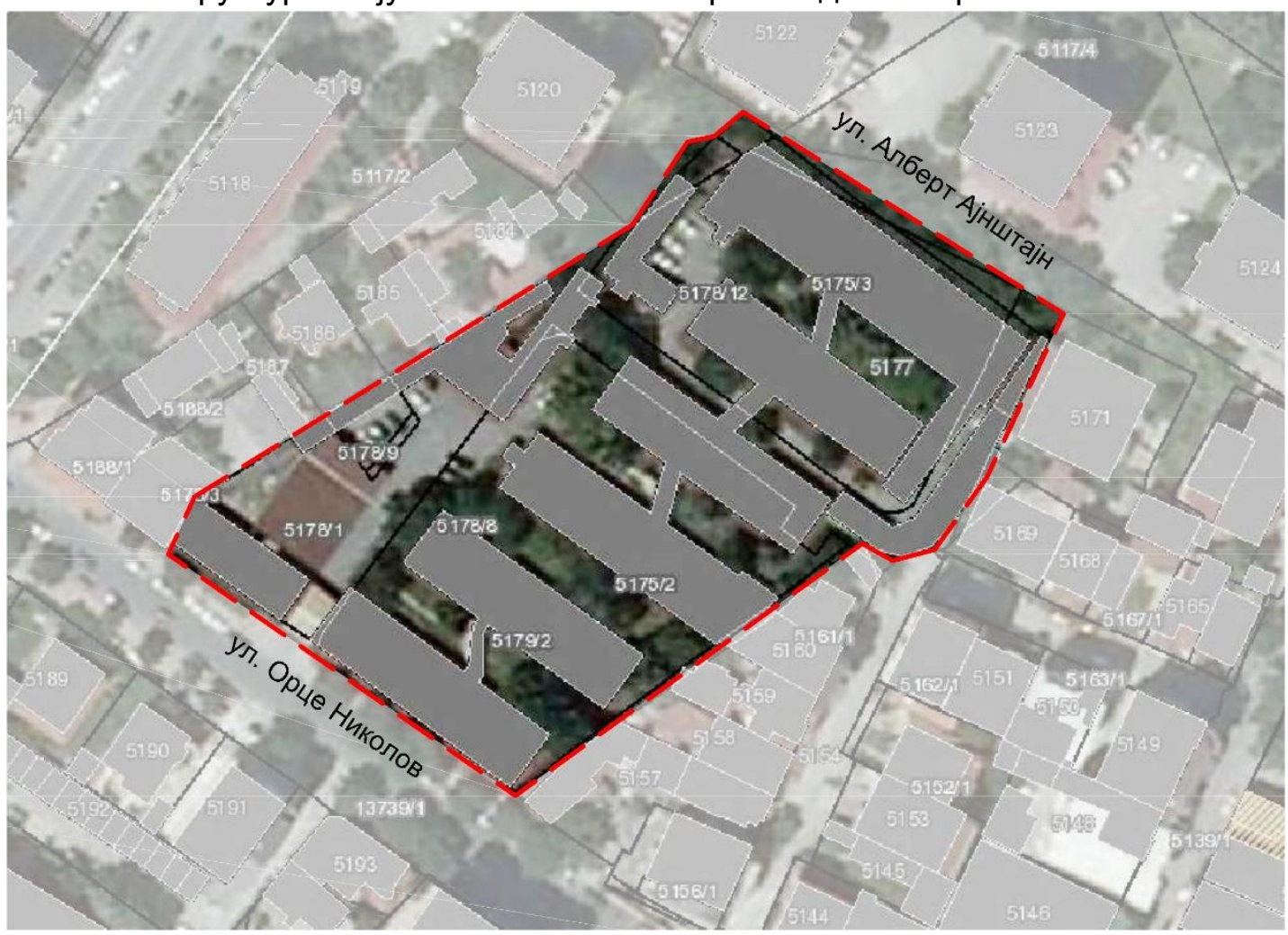

сл.57- графички приказ на К.П на предметниот опфат

Изменувањето и надополнувањето на Деталниот урбанистички план за Дебар Маало 1 , Општина Центар, од ноември 2012 година, на предметната локација, предвидува 2 
објекти од класата на намени Б- комерцијални и деловни намени, со максимална висина на венец 18м и подземен паркинг простор со капацитет од 234 и 164 возила соодветно. На предметниот опфат се предвидени две нови улици (продолжение на ул. "Донбас" и новопроектирана улица која ги врзува ул. “Орце Николов" и ул. "Алберт Ајнштајн”) како дополнителни пристапи и подобрена циркулација околу планираните објекти.

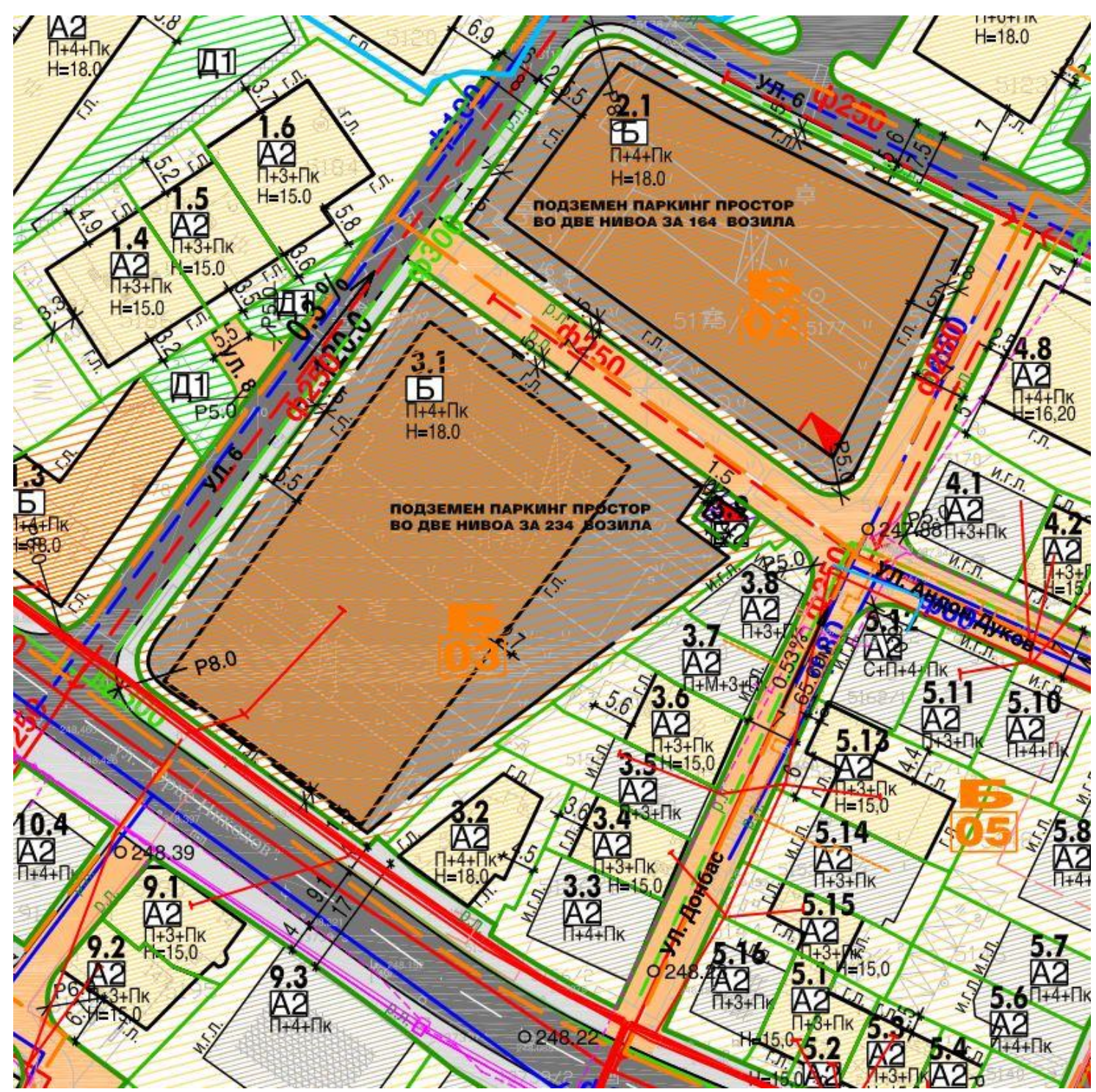

сл.58- ДУП донесен 11.2012

Во оваа фаза на проектантскиот дел на магистерскиот труд се врши реквалификацијата на парцелите 3.1 и 2.1 од Деталниот урбанистички план за Дебар Маало 1 од ноември 2012 година и се предвидува намена на индивидуално домување во типологијата на ниските станбени структури.

Во делот од истражувањето на типоморфолошката анализа на просторниот контекст на локацијата се нагласи потребата за постоење на архитектонската типологија на една витална просторна фрорма на домување, едносемејните куќи на ниво на Дебар Маало, попрецизно, куќи во низа со цел да се задоволи поголема густина на во рамките на опфатот.

\subsection{2 Анализа на архитектонско- урбанистичкиот зафат}


Пред да започне процесот на проектирање неопходно е да се напоменат одредени промени и интервенции кои би настанале на постоечката ситуација со цел да се добие една чиста слика за локацијата на која би се поставиле објектите.

- Демонтирање и рушење на постоечките приземни бараки кои се во лоша состојба

- Продолжување на улицата "Донбас" до крајната линија на зафатот, со цел да се овозможи соодветен пристап до локацијата

- Вметнување на нова улица која ќе ги поврзе постоечките улици "Орце Николов" и “Алберт Ајнштајн” која ќе формира блок и ќе овозможи дополнителен пристап и подобрена циркулација околу локацијата

Концептот на новопредвидената ниска станбена структура зависи од повеќе фрактори:

- Постоечката доминантна типологија и класата на намена која ја претставува

- Проектната програма ја одредува структурата на објектите како и поставеноста на содржините и нивната меѓусебна комуникација

Композицијата од слободностоечки станбени кластери (куќи во низа) со која се карактеризира овој урбанистички зафат е од пресудно значење за нивното индивидуално функционирање, пристап до нив, циркулација низ самата локација и поврзаноста на различните проектни содржини.

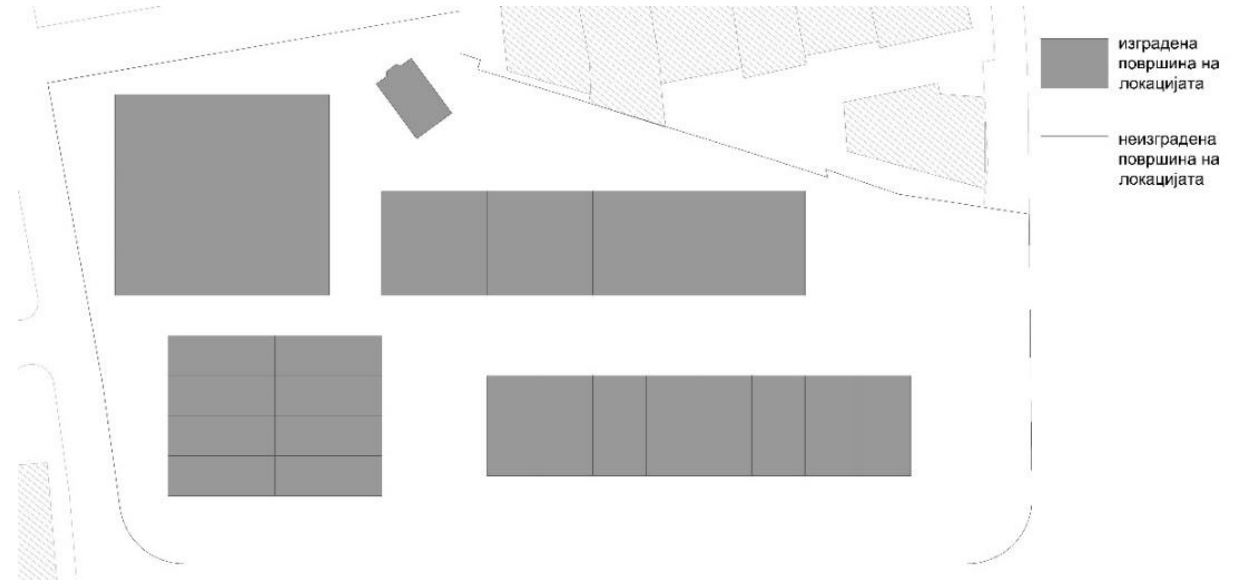

сл.59- Приказ на изградена/ неизградена површина(полно/ празно)

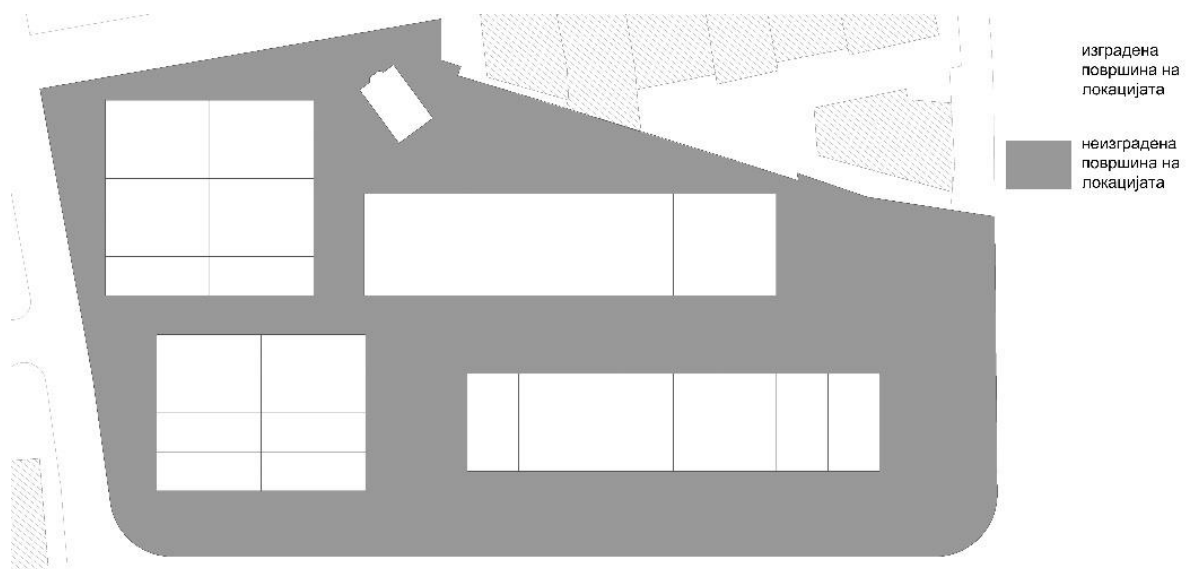

сл.60 - Приказ на неизградена/ изградена површина (полно/ празно) на локацијата 


\begin{tabular}{|l|l|}
\hline ПОВРШИНА НА ПРИЗЕМЈЕ & $2641 \mathrm{~m} 2$ \\
\hline РАЗВИЕНА ПОВРШИНА & $5268 \mathrm{~m} 2$ \\
\hline КОЕФИЦИЕНТ НА ИСКОРИСТЕНОСТ & 2 \\
\hline БРОЈ НА СПРАТОВИ & $\begin{array}{l}\text { Тип 1- Подрум+П+1 } \\
\text { Тип 2- П } \\
\text { Тип 3- Подрум+П+1 } \\
\text { Тип 4- Подрум+П+1 }\end{array}$ \\
\hline МАКСИМАЛНА ВИСОЧИНА & $\begin{array}{l}\text { Тип 1- Н=5.4м } \\
\text { Тип 2- Н=4.2м } \\
\text { Тип 3- Н=6.8м } \\
\text { Тип 4- Н=6.8м }\end{array}$ \\
\hline ОСНОВНА НАМЕНА & А- Домување \\
\hline ПРОЦЕНТ НА ИЗГРАДЕНОСТ & $65 \%$ \\
\hline ТА & \\
\hline
\end{tabular}

Табела 2- Табела со нумерички податоци за објектите и површината што ја зафаќаат

Доминантната застапеност на основната намена А- Домување, поточно А1- Домување во индивидуални семејни куќи, се така поставени да може непрекинато да се одвиваат функциите во рамките на целиот опфат- блок. На опфатот се предвидени и дополнителни содржини кои го зголемуваат квалитетот на живеење за корисниците на блокот како синтеза на природата и архитектурата во текстурата на градот. Преку анализата полно/ празно на локацијата, јасно се гледа изградената и неизградената површина во рамките на опфатот. Преку оваа анализа се воочува композициската поставеност на постоечките објекти и се нагласува човекомерноста и соодносот на природата и архитектурата во текстурата на градот на ниво на блокот.

Што се однесува до сообраќајното решение околу предметната локација: предвидено е продолжување на улицата “Донбас" до крајната линија на зафатот, со цел да се овозможи соодветен пристап до локацијата и вметнување на нова улица која ќе ги поврзе постоечките улици “Орце Николов" и “Алберт Ајнштајн” која ќе формира блок и ќе овозможи дополнителен пристап и подобрена циркулација околу локацијата. Во рамките на опфатот предвидена е еднонасочна улица која примарно служи за пристап со автомобил до куќите во внатрешноста на блокот. Стационарниот сообраќај за куќите кои немаат обезбедено паркинг простор во рамките на куќата е организирано во рамките на опфатот во непосредна близина до соодветната куќа. Обезбедени се и дополнителни паркинг места за посетители. 


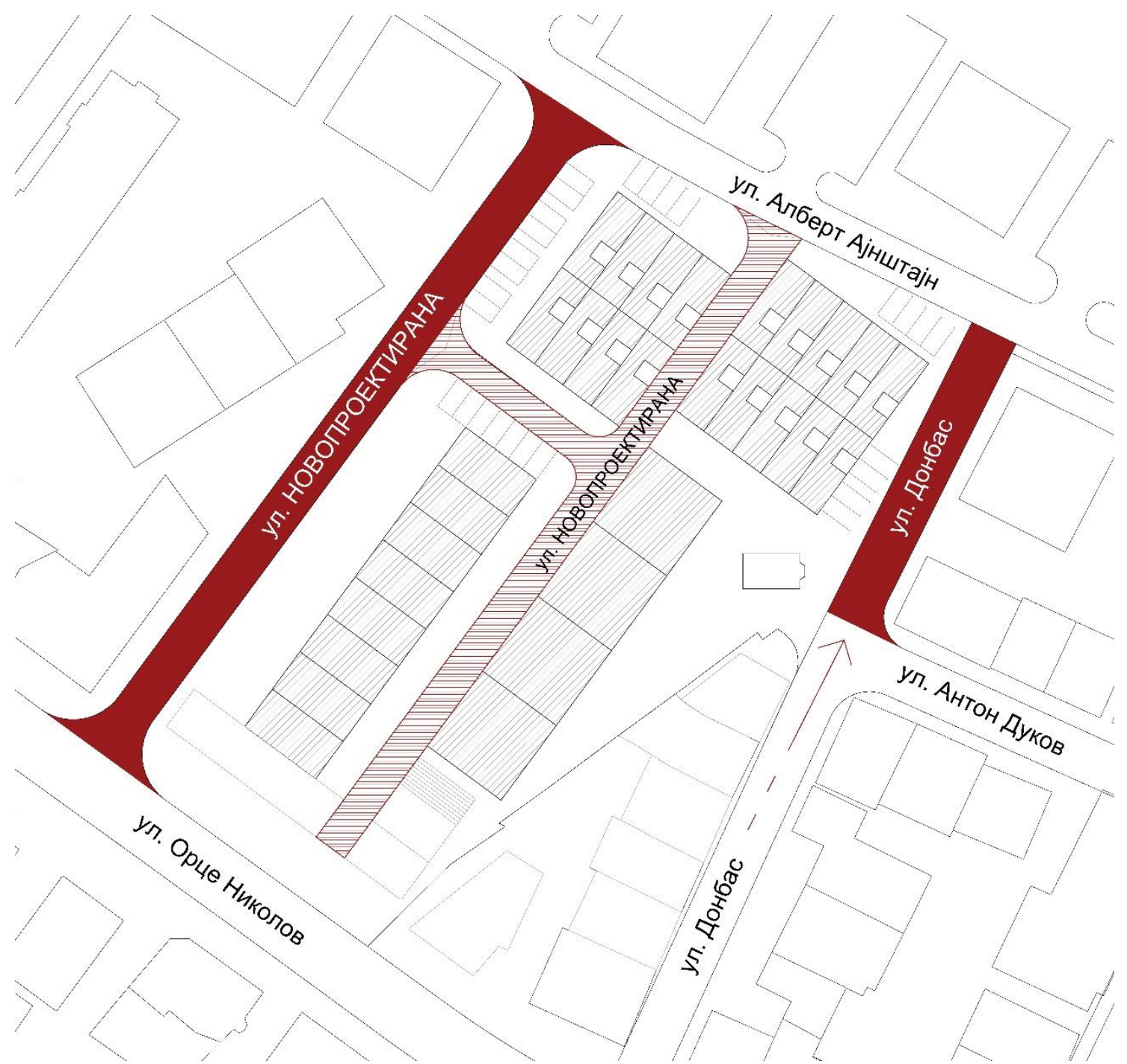

сл. 61- Шематски приказ на сообраќајното решение на опфатот

\subsection{3 Анализа на архитектонски концепт}

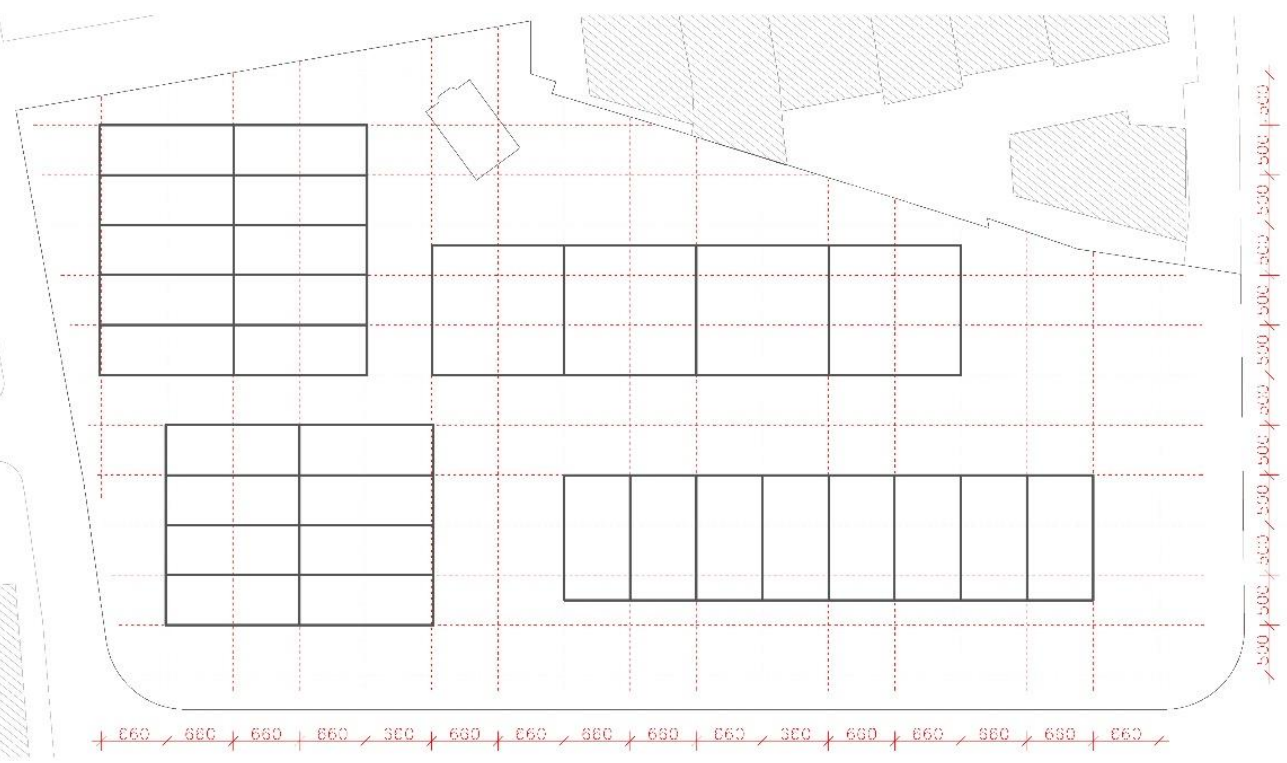

сл.62- Шематски приказ на употребена модуларна мрежа 
Димензиите на употребениот проектантски модул се детерминирани според намената на објектите, А1- домување во индивидуална семејна куќа. Модулот изнесува $660 \mathrm{~cm} \mathrm{/}$ $500 \mathrm{~cm} \mathrm{и} \mathrm{со} \mathrm{негова} \mathrm{мултипликација} \mathrm{низ} \mathrm{целиот} \mathrm{опфат} \mathrm{е} \mathrm{добиена} \mathrm{мрежа} \mathrm{според} \mathrm{која} \mathrm{се}$ поставени кластери од станбени низи, димензијата на една куќа од сите четири типови и просторот помеѓу нив. Овој начин на проектирање, според соодветниот модул овозможува задржување на човекомерноста на самите единици и соодносот на изградените кластери и неизградениот простор.

Првата детерминанта при фрормирање на концептот на тезата претставува имплеметирање на намената домување во ниска станбена структура, истовремено постигнувајќи висока густина на изграденост. Како соодветен модел на тие детерминанти одбрана е типологијата на куќа во низа, а со цел да се задоволи и диверзитетот на животните стилови, применети се четири варијации на станбени кластери.

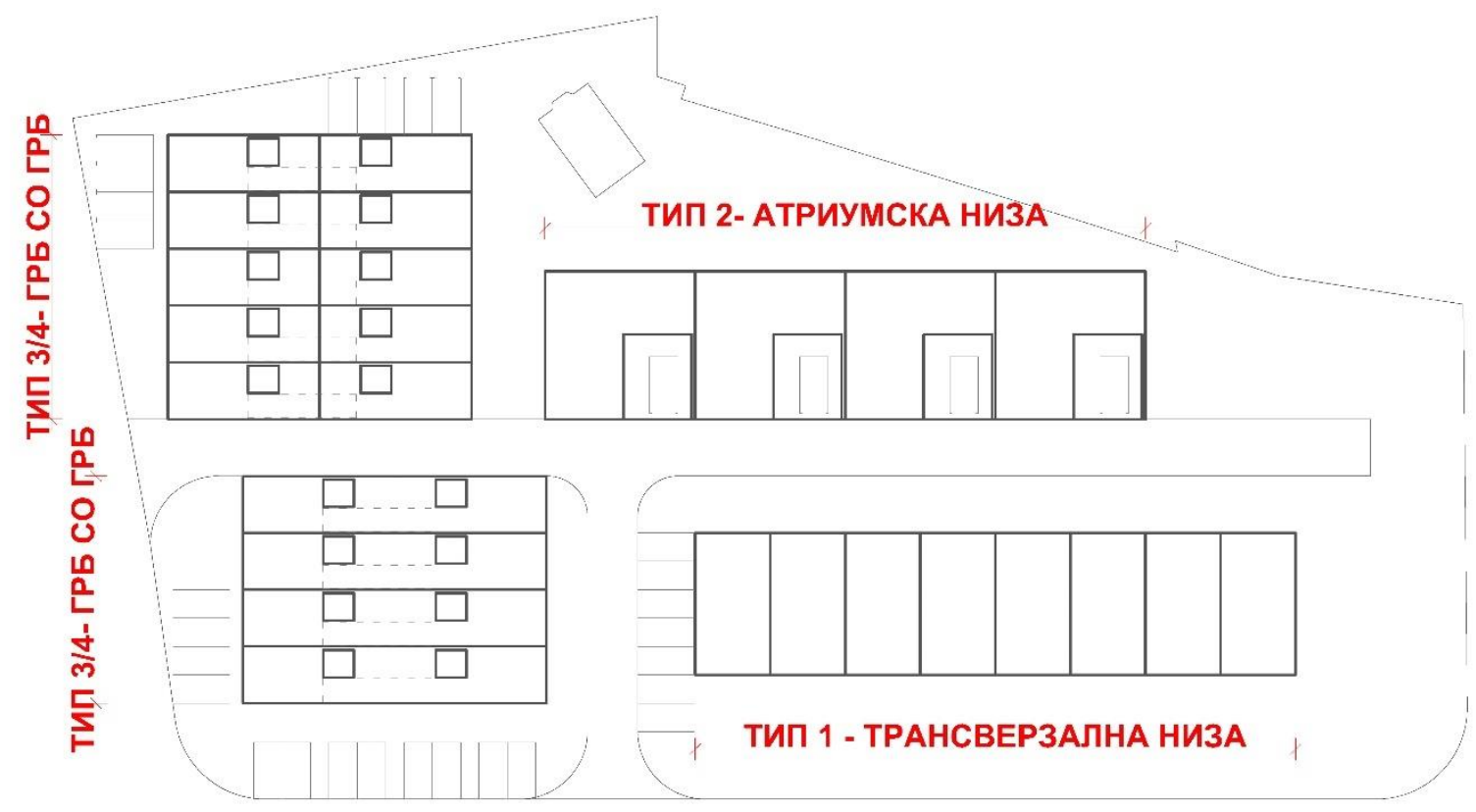

сл.63- Шематски приказ на употребени типови и нивна местоположба во рамките на опфатот

Тип 1 - Трансверзална низа

Именувањето на првиот тип на куќи во низа се должи на поставеноста на скалиштето во внатрешноста на куќата. Трасверзалното поставено скалиште спротивно на должината на куќата побарува поширок распон на самата куќа (6.6м). Покрај трансверзално поставено скалиште, композицијата на катовите и нивната поставеност формира вертикална поделба на полунивои во рамките на куќата. Од друга страна, поместувањето кон подолгите страни на куќата овозможува полунивото да биде осветлено од двете страни.

Тип 2 - Атриумска низа

Атриумската низа е именувана од очигледни причини. Таа е единствената од употребените типови кои се развива на едно ниво, а тоа е овозможено од големото двориште кое прима природно осветлување на повеќе простории, а со тоа и поголема слобода во дизајнот и подноставно решение и димензионирање на просториите. 
Тип 3/4 - Грб со Грб

Низата грб со грб е прототип на просторна ефикасност и е идеално прилагодена за постигнување на висока станбена густина. Бидејќи е еднострано ориентирана од страната на влезот, можностите во дизајнот на оваа куќа се чинат ограничени. Само во комбинација со внатрешни дворови или кровни тераси може да го покаже својот полн потенцијал.

Како дополнителни содржини во рамките на опфатот предвидено е партерно уредување со социјални содржини и зеленило. Социјалните содржини се сместени во две јадра кои физички се поврзани со тесна патека, но истовремено визуелно одвоени заради природата на програмата која е предвидена. Јадрото кое излегува на пофрекветната улица "Орце Николов" содржи дрворед и водени површини кои фрормираат заштитен појас кон првиот ред на куќи и каскадно фрормирано гледалиште кое има потенцијал да прими организани настани или спонтана социјализација на жителите во опфатот, околните жители и минувачи. Второто јадро е предвидено во внатрешноста на локацијата, како поинтимен дел, мал плоштад врамен од зелени површини кој во својот центар наоѓа верски христијански храм. Дрворедите се предвидени долж периметарот на предметниот опфат.

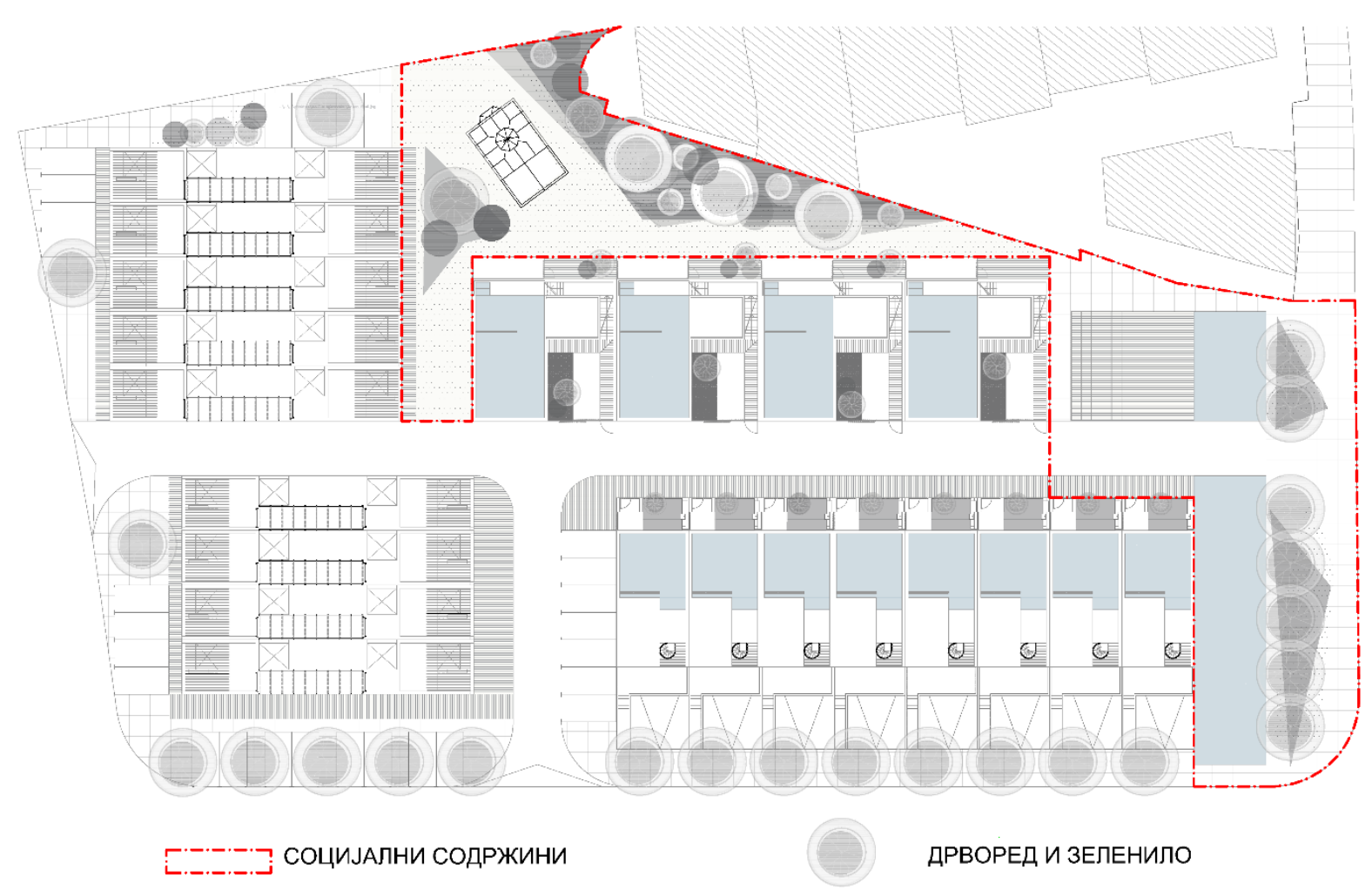

сл.64- мапирање на социјалните содржини 


\subsection{4 Програмска анализа по спратови}

Основа на подрум

Со подрумски простор располагаат тип 1 и тип 3/4. Во случајот на Тип 1

(Трансверзална низа) во подрумскиот простор има две намени: простор за подземно паркирање на еден автомобил, чиј пристап е надворешен, а во остатокот од подрумскиот простор е предвидена дополнителна просторија која може да се користи како остава и простор со мијалник. Пристапот до подрумот има топла врска со внатрешноста на куќата преку внатрешни скали кои се симнуваат од високото приземје. Подрумските простории предвидени во Тип 3/4 (Грб со Грб) имаат проток на природна сончева светлина и може да се користат како простори за складирање или за други намени по избор на корисникот. Поврзани се со внатрешно скалиште кое се симнува од приземјето и припаѓа на истата единствена вертикална комуникација на куќата. Висината на подрумскиот простор е постигната со денивелација на половина од просторната организација во основата.

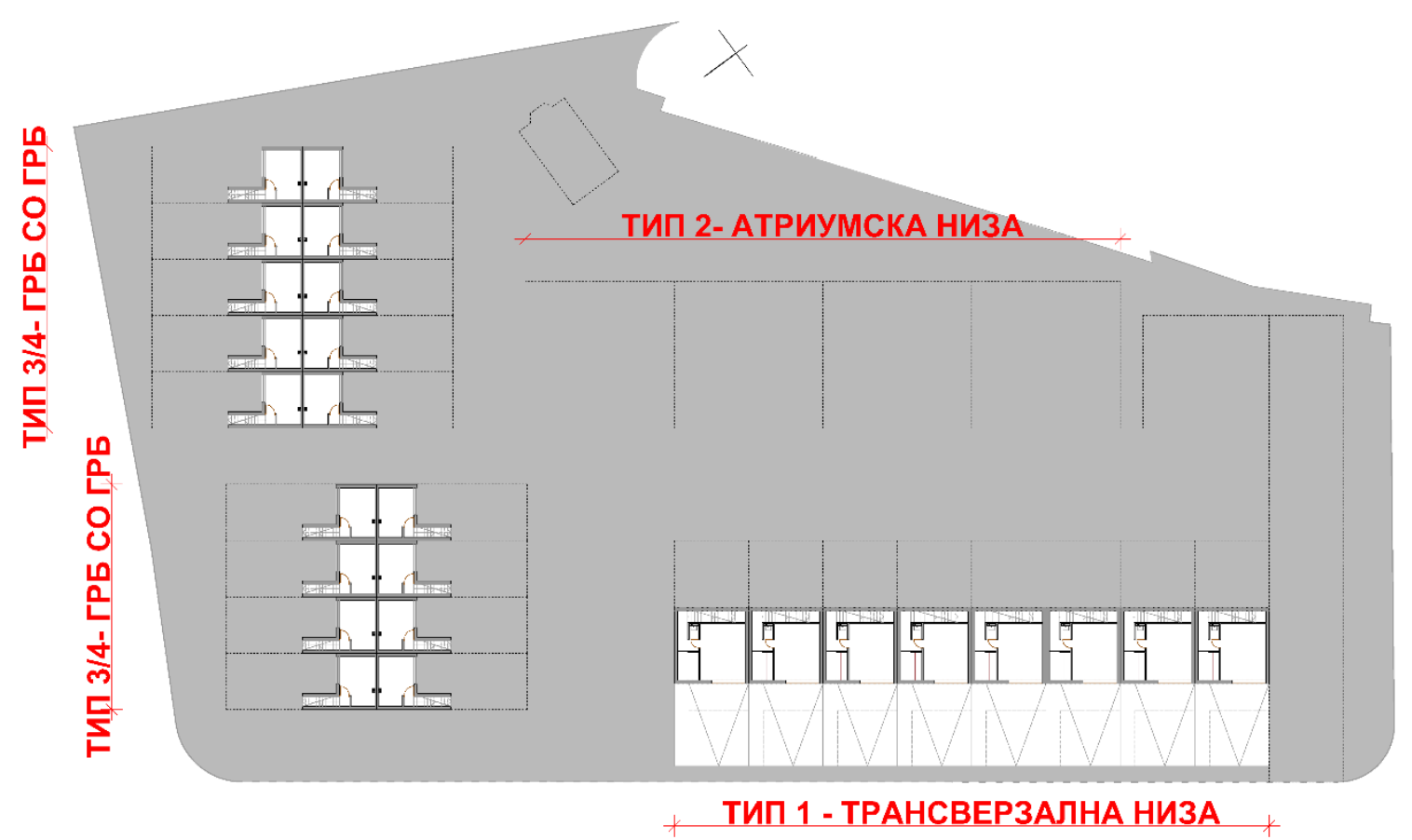

сл.65 - графички приказ на основа на подрум

Основа на приземје

Трансверзалната низа има високо приземје чија денивелација од нултата кота на теренот се должи на обезбедувањето на подземен простор за паркирање на едно возило. Таа има главен влез на фронтот на новопроектираната улица и т.н. економски влез од задниот двор. Задниот двор е предвиден да има мал простор со зеленило и средно- висока вегетација. Предвиден е и мијалник за олеснето одржување на дворната површина. Кујната, трпезаријата и гостинскиот тоалет се сместени на високото приземје кај влезот на куќата, а дневната просторија е денивелирана кон нултата кота на теренот.

Сите простории живеење се распространети на приземјето кај атриумската низа (предсобје, дневен простор, кујна и трпезарија, гостински тоалет, бања, родителска спална и две детски соби). Таа располага со сопствено паркирање во дворот кој има и 
површина со зеленило, а под скалите кои водат кон кровниот базен со водена површина. Главниот пристап е низ дворот кој се наоѓа во внатрешноста на опфатот на новопроектираната улица. Економскиот пристап е овозможен од задниот дел на куќата кој води кон кујната.

Низата Грб со Грб има една светла фасада на влезниот дел и темна фрасада (грб). На приземјето се предвидени кујната и трпезаријата, гостинскиот тоалет и една спална соба. Тука се и внатрешните дворови кои овозможуваат дополнителна природна светлина на сите простории и нивно користење кога метеоролошките услови се пријатни.

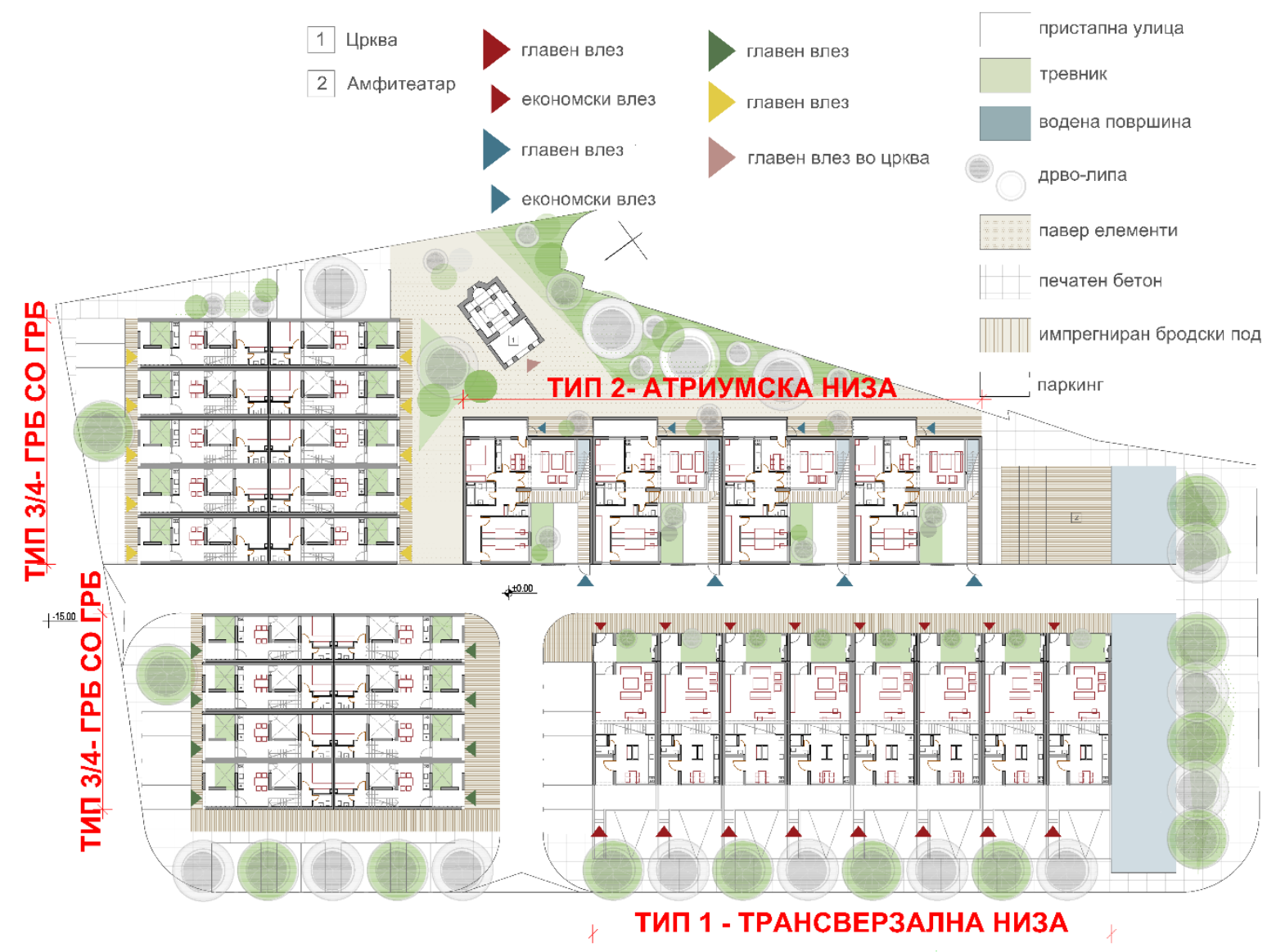

сл.66 - графички приказ на основа на приземје

Основа на кат

Кај трансверзалната низа просториите за спиење се предвидени на катот. Содржи една родителска спална со сопствена бања и две детски спални со заеднички санитарни јазли. Малата тераса има пристап од заедничките комуникации и таму се сместени спиралните скали кои водат до кровниот базен.

Кај атриумската низа на ова ниво го наоѓаме кровниот базен чија длабочина е обезбедена со повисоката плафонска висина на дневната соба која пак добива дополнително зенитално осветлување. Над дневната соба има сончева проодна тераса која е дополнителна содржина на базенот.

Кај низата грб со грб денивелацијата која го овозможува подрумскиот простор последично се реперкуира на сите погорни катови. Така, заедничките простории и 
собите за спиење кои се наоѓаат на истиот кат се просторно поделени со денивелација која обезбедува приватност и тој принцип е дополнително поддржан од тампон зоната формирана од внатрешниот двор и скалишниот простор приврзан за него. Тука ги наоѓаме, дневниот простор, еднокреветна спална, бањата и терасата која има пристап од заедничкиот простор.

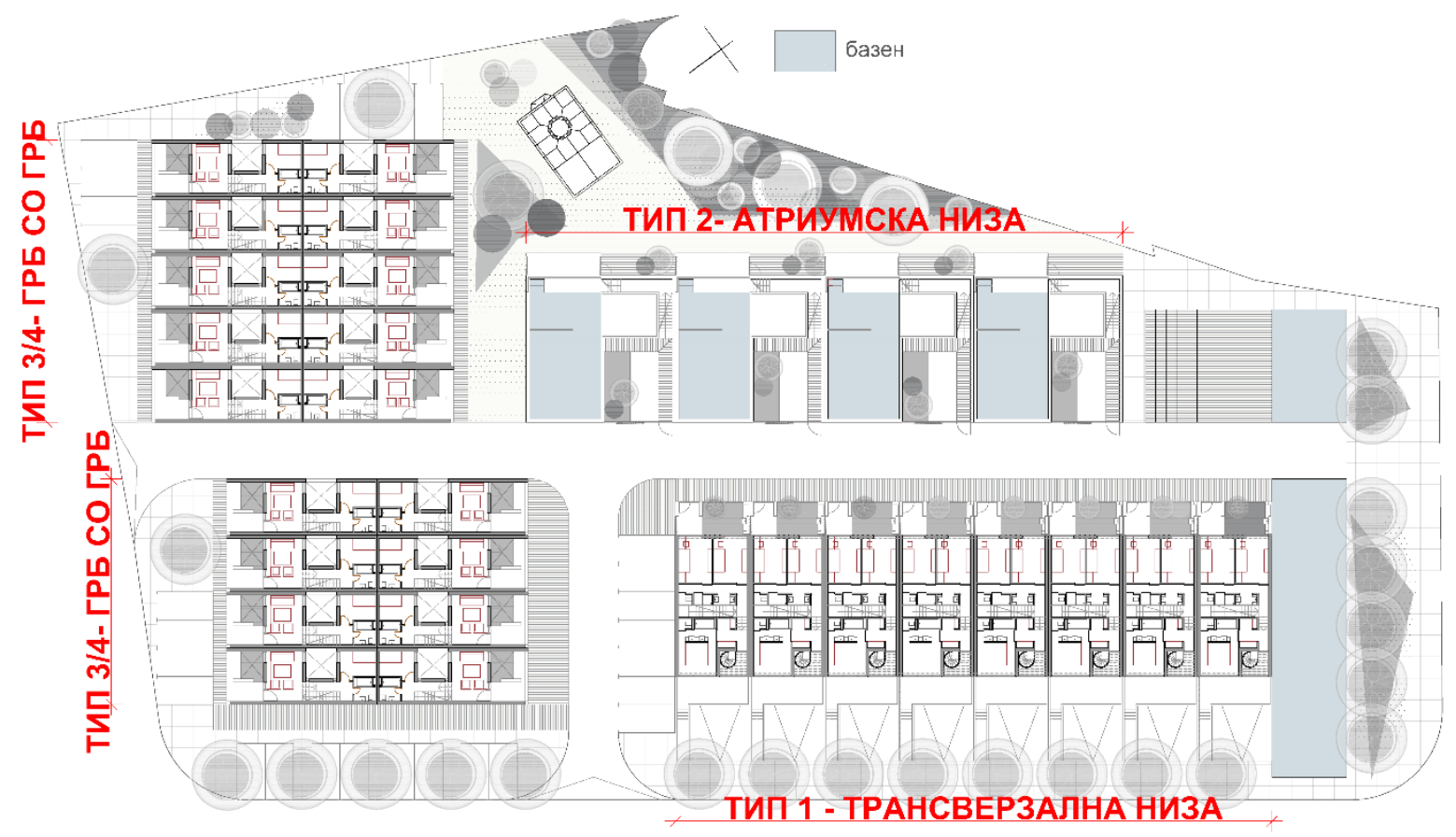

сл.67 - графрички приказ на основа на прв кат

Основа на втор кат и петта фрасада

Спиралните скали од терасата на катот кај трансверзалната низа водат кон кровниот базен кој исто располага со мала проодна сончева тераса како дополнителна содржина на базенот. Спиралните скали се сместени во бела цилиндрична форма која се издвојува од габаритот на куќата и претставува обликовен белег на низата во рамките на опфатот.

На овој кат можеме да најубаво да го воочиме значењето на нумерацијата на низата Грб со Грб (Тип 3/4). Тип 3 и Тип 4 се разликуваат во тоа што едната куќа од парот располага со дополнителна содржина кој го формира "вториот кат" до кој се пристапува со продолжување на истата скалишна вертикала. Просторот е предвиден како транспарентен "стакленик”, отворен со погледите кон околината и е именуван како хоби простор со цел неговата функција да ја интерпретира корисникот/ корисниците. 


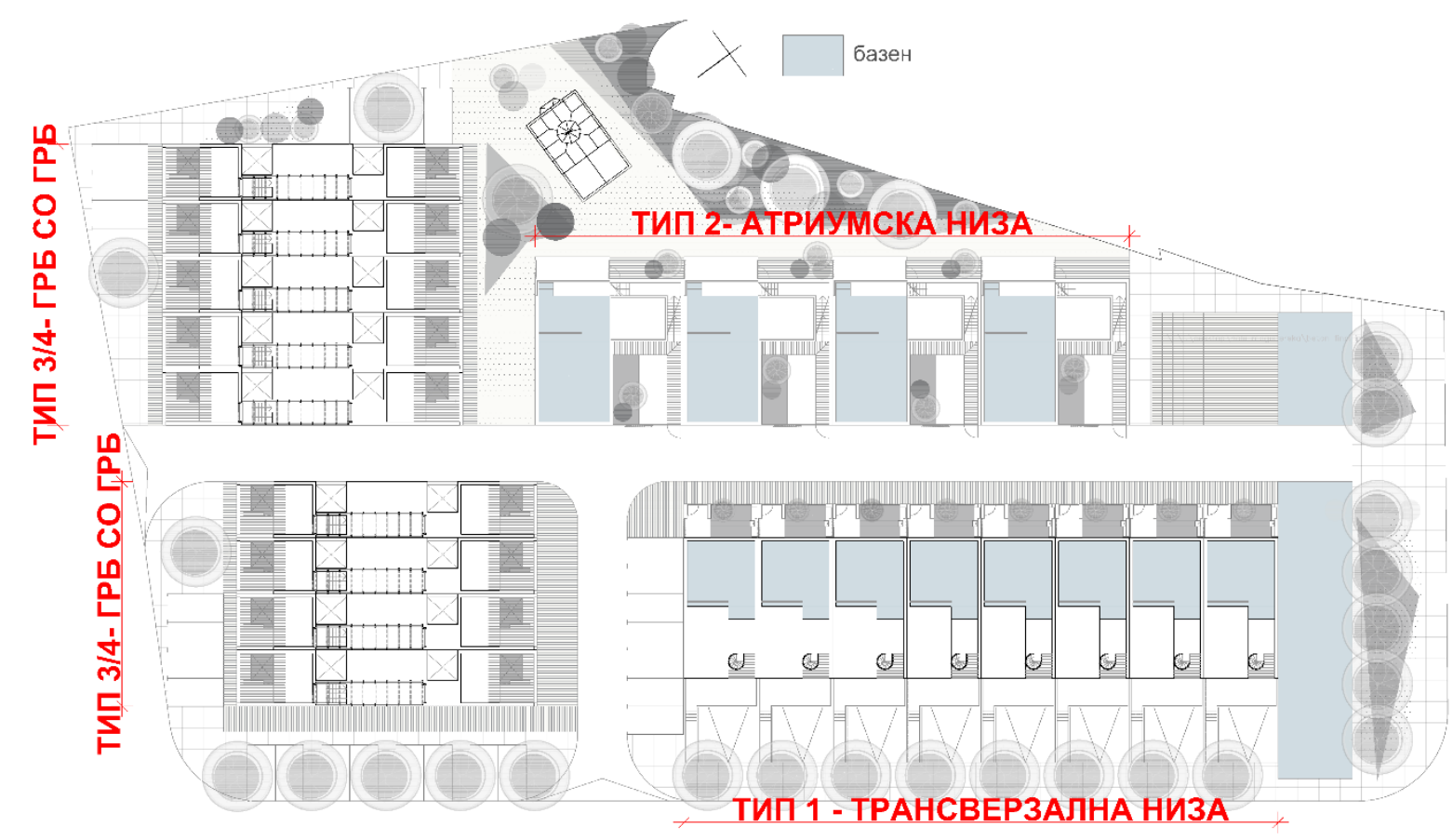

сл.68 - графички приказ на основа на втор кат и петта фасада

\subsection{5 Конструкција и применети материјали}

Конструкцијата кај сите објекти е предвидена како конструктивен систем од вертикални и хоризонтални армиранобетонски носиви елементи. Примарното димензионирање на носивите елементи, без статички пресметки и геодетски анализи, е определено со пресеците: А.Б. плоча- $20 \mathrm{~cm}$, А.Б. плоча под базените- $40 \mathrm{~cm} \mathrm{и} \mathrm{темелна} \mathrm{плоча-} 50 \mathrm{~cm}$. Гредите се со ширина- 30см и висина од 35cм, каде катната височина не надминува $3 \mathrm{~m}$ во ниту една од низите. Сидовите се предвидени како “сендвич" зидови од 30см, чиј состав е предвиден со слој од 10см бетон кој ентериерот на куќата , 5см термичка изолација и $15 \mathrm{~cm}$ пигментиран бетон чиј естетски изглед не бара дополнителна фрасадна обработка. Стаклените хоби простори предвидени кај низата Грб со Грб имаат челична конструкција на растер од $110 \mathrm{~cm}$. Каскадното гледалиште е формирано од лесна челична рамкова конструкција.

Во партерното уредување има предвидено диверзитет на материјали за надворешно уредување кое се должи на одлуката нултата кота во рамките на опфатот да нема денивелација, односно пристапните улици и остатокот од партерот да бидат на една иста кота- кота на тротоар. Така, пристапните улици, тревникот и водените површини имаат стандардна обработка. Тротоарот на периметарот на блокот е предвиден да се обработи со печатен бетон со фуги кои формираат квадратни текстури, внатрешниот плоштад околу црквата да биде со подна обработка од помали павер елементи со кружна фрорма и непосредните пристапи влезовите на куќите да бидат со обработка импрегниран бродски под за надворешна употреба. Истата материјализација се употребува и за каскадното гледалиште.

Бетонот, челикот, стаклото и дрвото се материјали кои ги сретнуваме во сите проекции на овој проект, како конструктвни и како материјали за завршна обработка. 


\section{ЗАКЛУЧОК}

“...Коцентрацијата на животот во големиот град му го одзема на човекот најдрагоценото: идиличното домување во индивидуална куќа...

...Вечен сон што тлее во срцето на секој човек е индивидуална куќа на земја. Квалитетот на домувањето не е само во земјата, туку многу повеќе во визбите, таваните и скриените катчиња на индивидуалната куќа. Тука се корените на живеењето, духовите на домот кои антиката ги нарекуваше лари. Тоа се нематеријалните симболи на постоењето низ времето...

...Големите градови сигурно нема да бидат толку скоро демонтирани, како што не можат да се очекуваат ненадејни промени и во општествените и економските односи. Но, нужно е да бидеме свесни и бистро да гледаме кон иднината...

“Одисејата е повест што има значење и за денешнината."- Кр. Н. Шулц Иднината ќе мора да го реши проблемот на големите градови кои сега слепо маршираат во црнила. Во сегашниве градови, колку повеќе станови се градат, толку повеќе луѓето остануваат без стан. Без сомнение, против сонот на индивидуалната куќа стојат извендредно силни аргументи од организациска, а особено од економска природа. Во нашата нова хипотетична перспектива на поинакво општество, кога националниот доход нема да се троши за средства за самоуништување, и таквите аргументи можат да се срушат. "26

Во овој извадок, Борис Чипан ја дефинира тезата домување. Во него се нагласува потребата за постоење на архитектонската типологија на една витална просторна форма на домување во градовите, едносемејните куќи, како и елементарните причини и последици на проширувањето/ згуснувањето на градежната маса во градовите.

Овие актуелни проблеми се разгледуваат на микролокација на ниво на еден урбан блок во Дебар Маало. Во ова истражување се нагласува социјалната структура преку реакција на локалните жители во Дебар Маало кои имаат формирано граѓанска иницијатива за посочување и решавање на овие проблеми кои произлегуваат од непочитување на човекомерноста и соодносот на изградените единици и неизградениот простор.

Архитектонскиот проект во ова истражување тежнее да одговори на сите гореспоменати предизвици и предвидува “идеална" композиција на неколку кластери од станбени низи од едносемејни куќи од типологијата на ниска станбена структура. Овој нов локален прототип на домување претставува реминисценција на некогашниот лик на Дебар Маало со нови, надградени дополнителни содржини кои би стимулирале поголеми социјални интеракции и кохезија кај корисниците и куќи чија програмска содржина соодветствува на современиот начин на живот. Четирите типови на низи ја задоволуваат потребата за диверзитет во стиловите на живеење, начинот на нивната поставеност го почитуваат соодносот на изградената и неизградената површина истовремено, одбраната типологија “куќи во низа" придонесуваат кон зголемувањето на урбаната густина како одговор на современите трендови и поткрепување на аспектите на економичност и одржливост.

\footnotetext{
26 Чипан, Борис, “111 тези за архитектурата”, Второ издание, 2002, стр. 32
} 
- Alexander, C. et al., A Pattern Language. Oxford University Press, New York, 1979

- Бакалчев, М., Домување како урбан фррагмент на примерот на Скопје. Необјавена докторска дисертација, Универзитет „Св. Кирил и Методиј“, Скопје, Архитектонски Факултет, 2004.

- Блажевска, 3., Повеќедворната станбена куќа во функција на хумано домување на старите луѓе во рамки на семејството. Необјавена докторска дисертација, Универзитет „Св. Кирил и Методиј“, Скопје, Архитектонски Факултет, 1991.

- Gausa, M., Housing, New Alternatives, New Systems. Birkhauser Publishers, Basel, Boston, Berlin, ACTAR, Barcelona, 1998.

- Константиновски, Георги, “Градителите во Македонија XVIII-XX ВEК”, Табернакул.

- Lack, Peter, Bruno Reichlins gebaute Architecturkritik, VDG Verlag and database for humanities, Weimar 1955.

- MVRDV, FAR MAX, Excursions on Density (ed.: Winy Maas and Jacob van Rijs with Richard Koek), 010 Publishers, 1998.

- Nestorović, B., Stambene zgrade. Naučna Knjiga, Beograd, 1952.

- Norberg-Schulz, C., Stanovanje. Gradjevinska knjiga, Beograd, 1990.

- Norberg-Schulz, C., Egzistencija, prostor i arhitektura. Gradjevinska knjiga, Beograd, 1975.

- $\quad$ Oliver, P., Dwelings. The House across the World, Phaidon, Oxford, 1987.

- Pfeifer, Gunter, Brauneck, Per, Row houses, A Housing Typology, Birkhauser Publishers, Basel, Boston, Berlin, 2008.

- Ранковиќ, Ж., Јован, “Станбени повеќекатници, Кули”, Скопје, 1975.

- Rapoport, A., House form and Culture, Prentice-hall, Inc. Englewood Cliffs,N.J., 1969.

- Тасиќ, С., Прототипови на домување на интегрирани животни стилови. Необјавена докторска дисертација, Унниверзитет „Св. Кирил и Методиј“, Скопје, Архитектонски Факултет, 2015.

- Thill, K., New Prototypes for Global Society. Atelier Kempe Thill and 010 Publishers, Rotterdam, 2005.

- Teut, Anna, "Von Typen und Normen, Maßreglern und Maßregelungen", Architektur und technisches Denken, 1985.

- Hajdeger, M., Misljenje i pevanje. Gradjevinska knjiga, Beograd, 1982.

- Hillier, B., Hansenb, J., The Social Logic of Space, Cambridge University Presse, 1984. 
